\title{
SUMMARY REPORT OF THE DOE DIRECT LIQUEFACTION PROCESS DEVELOPMENT CAMPAIGN OF THE LATE TWENTIETH CENTURY: TOPICAL REPORT
}

\author{
July 2001 \\ DOE Contract DE-AC22-94PC93054
}

Contributors:

F. P. Burke

S. D. Brandes

D. C. McCoy

R. A. Winschel

CONSOL Energy Inc.

Research \& Development

4000 Brownsville Road

South Park, PA 15129-9566

- and -

D. Gray

G. Tomlinson

Mitretek Systems

7525 Colshire Drive

McLean, VA 22102-7400 


\section{Disclaimer}

This report was prepared as an account of work sponsored by an agency of the United States Government. Neither the United States Government nor any agency thereof, nor any of their employees, makes any warranty, express or implied, or assumes any legal liability or responsibility for the accuracy, completeness, or usefulness of any information, apparatus, product, or process disclosed, or represents that its use would not infringe privately owned rights. Reference herein to any specific commercial product, process, or service by trade name, trademark, manufacturer, or otherwise does not necessarily constitute or imply its endorsement, recommendation, or favoring by the United States Government or any agency thereof. The views and opinions of authors expressed herein do not necessarily state or reflect those of the United States Government or any agency thereof. 


\section{TABLE OF CONTENTS}

Chapter 1 - INTRODUCTION

Page

Chapter 2 - AN ANALYSIS OF THE ACCOMPLISHMENTS OF THE DOE DIRECT COAL LIQUEFACTION PROGRAM, 1976-2000

Chapter 3 - SRC-II PROCESS

$\begin{array}{ll}\text { Chapter } 4 \text { - H-COAL PROCESS } & 27\end{array}$

Chapter 5 - LUMMUS INTEGRATED TWO-STAGE LIQUEFACTION PROGRAM

Chapter 6 - WILSONVILLE TWO-STAGE LIQUEFACTION PROGRAM

Chapter 7 - HYDROCARBON RESEARCH, INC./HYDROCARBON TECHNOLOGIES, INC. TWO-STAGE LIQUEFACTION PROGRAM

Chapter 8 - SELECTED ACCOMPLISHMENTS OF CONSOL'S PROCESS DEVELOPMENT SUPPORT PROGRAM

\section{LIST OF TABLES}

$\underline{\text { Table }}$

2-1 Economics of Coal Liquefaction

2-2 Properties of Syncrude and Typical Crude

4-1 Normalized Material Balance Data Comparison for Pilot Plant and PDU wt \% Moisture-Free Coal

4-2 Product Properties Comparison

5-1 Lummus ITSL PDU Run Operating Conditions

5-2 Lummus ITSL PDU Yield Structure with Indiana V Coal in Original Operating Mode

5-3 Elemental Composition of Product Fractions

6-1 Wilsonville Operating Conditions

6-2 Feed Coal Analyses

6-3 Process Yields for Selected Steady-State Run Periods

6-4 Distillate Properties from Wilsonville CC-ITSL Operations

7-1 Comparison of H-Coal, Direct-Coupled Two-Stage Liquefaction, and Catalytic Two-Stage Liquefaction Process Features

7-2 Comparison of HRI Coal Liquefaction Process Results

7-3 Comparison of Yield Data from Runs Made with Four Different Catalysts

7-4 Comparison of Cleaned Illinois No. 6 Coal Feed Samples

7-5 Experimental Results of Bottoms and Vacuum Gas Oil Extinction CTSL Bench Unit Operations with Ohio Coal 


\section{LIST OF TABLES (Continued)}

$\underline{\text { Table }}$

7-6 Operating Conditions and Performance Summary for Temperature

Sequence Test with Black Thunder Mine Subbituminous Coal

7-7 Tests of Water-Gas-Shift Catalysis

7-8 Comparison of PDU Co-Processing Demonstration, Bench-Scale Test, and Design Basis

7-9 Performance Comparison for Co-Processing in the HTI CoPro Plus Process

7-10 Economic Comparison of H-Coal and CTSL and Single-Stage Coal/Oil Co-Processing

7-11 Summary of PRB Subbituminous Coal CTSL Economics 107

7-12 Economic Comparison for HTI CoPro Plus Process

108

\section{$\underline{\text { Figure }}$}

\section{LIST OF FIGURES}

3-1 SRC Process Schematic

3-2 Schematic Process Flow Diagram of Fort Lewis SRC II Pilot Plant

3-3 SRC-II Demonstration Plant

4-1 H-Coal Reactor

4-2 Block Flow Drawing -- H-Coal Process

5-1 Lummus ITSL PDU, Original Operating Mode

5-2 Lummus ITSL PDU - Process Flow Diagram

6-1 Block Flow Diagram of ITSL Operation

6-2 Block Flow Diagram of DITSL Operation

68

6-3 Block Flow Diagram of RITSL Operation

69

70

6-4 Block Diagram of CC-ITSL Process

6-5 Schematic Flow Diagram of CCR Unit with Interstage Separation and Atmospheric Flash Bottoms Recycle

6-6 Simplified Flow Diagram of the Close-Coupled ITSL Coal Liquefaction System with Interstage Separation and with Vacuum Flash Bottom Recycle

6-7 Simplified Flow Diagram of the Close-Coupled ITSL Coal Liquefaction System without Interstage Separation and with Atmospheric Flash Bottoms Recycle

7-1 HRI Catalytic Two-Stage Unit (Reference 1)

7-2 Catalytic Two-Stage Liquefaction (Simplified Process Flow Diagram), Extinction Recycle

7-3 POC Facility at Hydrocarbon Research, Inc. (Simplified Flow Plan)

7-4 HRI's Catalytic Two-Stage Coal/Oil Co-Processing (Simplified Flow Plan)

7-5 HRI's CoPro Plus Process (Simplified Schematic) 


\title{
SUMMARY REPORT OF THE DOE DIRECT LIQUEFACTION PROCESS DEVELOPMENT CAMPAIGN OF THE LATE TWENTIETH CENTURY: TOPICAL REPORT
}

\begin{abstract}
Following the petroleum price and supply disruptions of 1973, the U.S. government began a substantial program to fund the development of alternative fuels. Direct coal liquefaction was one of the potential routes to alternative fuels. The direct coal liquefaction program was funded at substantial levels through 1982, and at much lower levels thereafter. Those processes that were of most interest during this period were designed to produce primarily distillate fuels. By 1999, U.S. government funding for the development of direct coal liquefaction ended. Now that the end of this campaign has arrived, it is appropriate to summarize the process learnings derived from it. This report is a summary of the process learnings derived from the DOE direct coal liquefaction process development campaign of the late twentieth century. The report concentrates on those process development programs that were designed to produce primarily distillate fuels and were largely funded by DOE and its predecessors in response to the petroleum supply and price disruptions of the 1970s. The report is structured as chapters written by different authors on most of the major individual DOE-funded process development programs. The focus of the report is process learnings, as opposed to, say, fundamental coal liquefaction science or equipment design. As detailed in the overview (Chapter 2), DOE's direct coal liquefaction campaign made substantial progress in improving the process yields and the quality of the distillate product. Much of the progress was made after termination by 1983 of the major demonstration programs of the "first generation" (SRC-II, H-Coal, EDS) processes.
\end{abstract}




\section{Chapter 1}

\section{INTRODUCTION}

\section{R. A. Winschel - CONSOL Energy Inc.}

\section{PURPOSE}

DOE has completed a 25-year campaign to develop direct coal liquefaction technologies for the production of liquid transportation fuels. This campaign was successful in greatly improving and expanding liquefaction technology. However, it was not successful in making the technology the basis for a commercial business, partially because the prices of conventional petroleum fuels did not rise during the 1980s and 1990s to the levels originally anticipated in the mid- and late 1970s. The general consensus of industry and government is that direct liquefaction technology will not be needed, nor will it be competitive with conventional fuels, for the foreseeable future. Therefore, although it may be appropriate to continue the development program at a modest level, a major development program such as that conducted during the last 25 years of the century is no longer justified. Nevertheless, it is possible that direct liquefaction will contribute to the world's hydrocarbon demand at some time in the future, as a source of liquid fuels, petrochemicals, or both. When it is appropriate in the future to begin a new development campaign, it is likely that few, if any, of those individuals deeply involved in the recent campaign will take part. As the current campaign closes, it is important that the lessons learned are identified and documented for the future while the community memory remains fresh.

\section{SCOPE}

This is a DOE-funded report and the focus will be on DOE-funded direct coal liquefaction technology development programs. It will be limited to those programs that meet the following criteria:

- $\quad$ They were funded by DOE and were primarily American programs.

- They were conducted during the last 25 years, largely in response to the OPEC actions. 
- $\quad$ They were designed to produce primarily distillate liquids.

- $\quad$ They used coal as the only principal feedstock.

- $\quad$ They were developed to the continuous bench-scale or larger-scale operations.

The process development programs that meet these criteria include:

- SRC-II Program

- H-Coal Program

- $\quad$ Lummus Two-Stage Liquefaction Program

- Wilsonville Two-Stage Liquefaction Program

- $\quad \mathrm{HRI} / \mathrm{HTI}$ Two-Stage Liquefaction Program

- Exxon Donor Solvent Program

- University of Kentucky Advanced Liquefaction Concepts Program

Each of these programs, except for the last two, is described in detail in a separate chapter. Chapter 2 includes discussions of the Exxon Donor Solvent Program and University of Kentucky Advanced Liquefaction Concepts Program.

Certain process development programs do not meet the criteria to fit the scope of this report. Thus, the NEDO and British Coal processes are not included, even though DOE provided some minor level of support. Project Gasoline (Cresap) and many early programs are not included, because they were conducted before the OPEC actions. SRC-I is not included, because it was designed to produce primarily a solid fuel. Coal/petroleum and coal/waste coprocessing technologies are not included as general topics because coal is not the only principal feedstock.

The last chapter, Chapter 8, summarizes selected accomplishments of CONSOL's work with DOE on the direct liquefaction campaign.

\section{FOCUS OF REPORT}

The issues addressed are primarily process development in nature, rather than fundamental science issues. They include process flows, operating conditions, coal feedstock characteristics, and product yields and quality, as well as the impacts of changes in process flows, operating conditions, and coal characteristics on product yields and quality. 


\section{INFORMATION SOURCES}

Primary sources include DOE technical reports, DOE and EPRI contractors' meeting papers, symposium papers, refereed scientific literature, contract review meeting handouts, patent literature and published books. The authors were participants in most of the development programs discussed. As such, they participated in many of the developments. 


\title{
Chapter 2
}

\section{AN ANALYSIS OF THE ACCOMPLISHMENTS OF THE DOE DIRECT COAL LIQUEFACTION PROGRAM, 1976-2000}

\author{
F. P. Burke and R. A. Winschel - CONSOL Energy Inc. \\ and \\ D. Gray and G. Tomlinson - Mitretek Systems
}

\section{SUMMARY}

The DOE direct coal liquefaction program, conducted between 1976 and 2000, resulted in the development and optimization of a commercially ready technology for the production of petroleum substitutes as refinery feedstocks. An intensive large scale demonstration program in the late 1970s and early 1980s demonstrated overall engineering feasibility. Subsequent process research and development work overcame the major technical and economic obstacles to commercialization of the process. As a result, direct liquefaction products that meet or exceed crude oil qualities can be made for about $\$ 30 / \mathrm{bbl}$. The technology was shown to be applicable to a wide range of coals in the United States. Fundamental research supported the process development effort, and provided direction in optimizing process performance. The DOE program met the goal of defining the costs and benefits of direct coal liquefaction as a strategic alternative to imported oil as a source of liquid fuels and petrochemicals.

\section{INTRODUCTION}

To understand the costs and benefits of the DOE direct coal liquefaction effort, it important to recognize that the program consisted of three main components. The first was the relatively large-scale demonstration of thermal/catalytic hydrogenation processes (referred to below as "Phase I" processes) in the 1970s and early 1980s. These demonstrations were done to accelerate the availability of coal liquefaction technology as a short-term response to the energy crisis of the 1970s. The second component was a more fundamental research program to investigate potential improvements in the thermal/catalytic processes, and to identify potential alternative processes, based on a better understanding of coal and process chemistry. The third component was a broadly based bench-scale and 
pilot plant process development program to overcome the technical and economic deficiencies encountered in the earlier Phase I demonstration programs. The processes developed in this third component of the program are referred to below as "Phase II" processes.

In 1976, U.S. petroleum imports cost $\$ 106$ billion (in 1999 dollars), and during the period from 1976 through 1999, the U.S. imported 68 billion barrels of imported crude oil, at a cost of $\$ 2$ trillion (1999 dollars). Since 1976, the average cost of a barrel of crude oil, in 1999 dollars, has been $\$ 29$. The overall cost of the DOE direct coal liquefaction program, through the year 2000 , was $\$ 3.6$ billion (1999 dollars), or $0.2 \%$ of the imported petroleum cost. As shown in the figure below, 89\% of the total spending occurred between 1976 and 1982. The majority was spent on large plants to demonstrate the Phase I processes. The DOE investment was matched by substantial investments by private industry, state governments, and academic institutions.

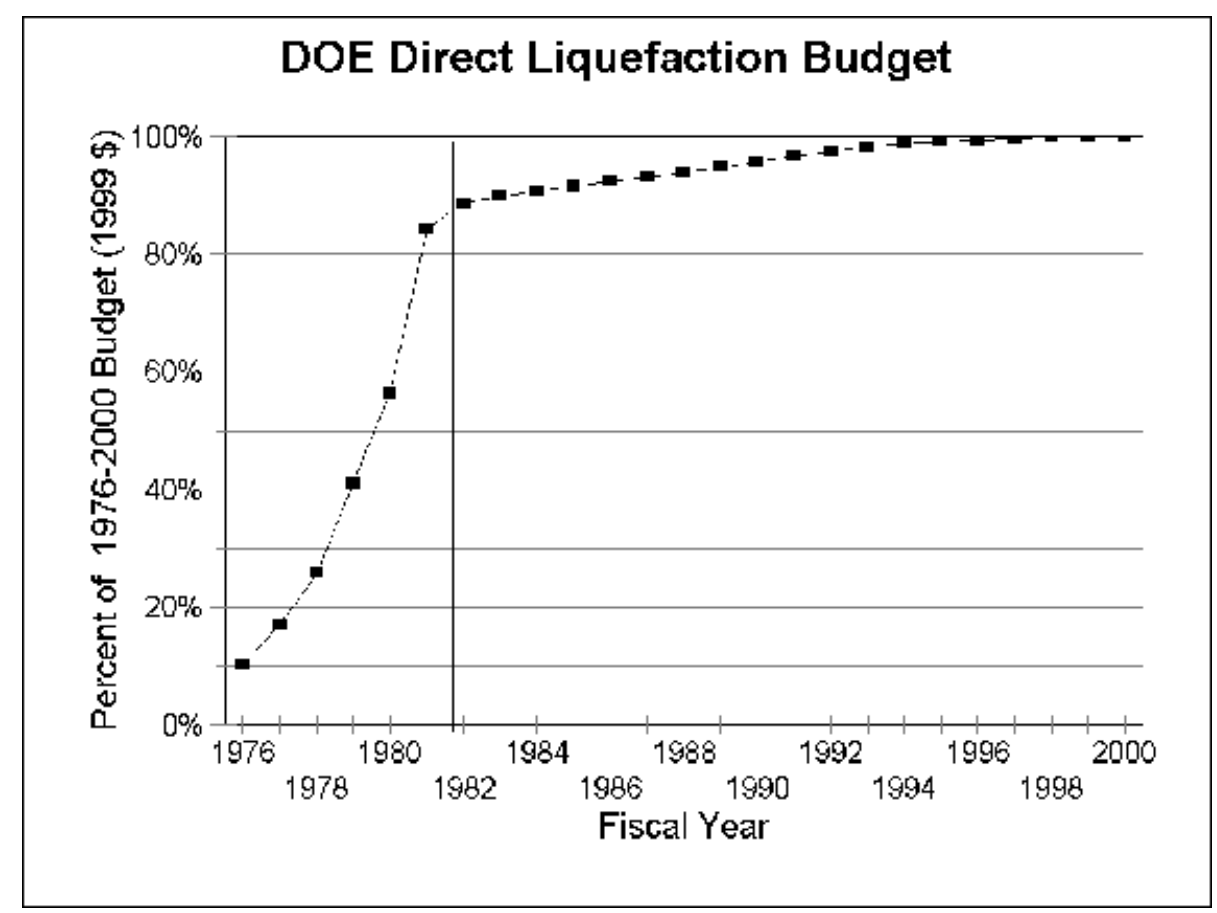

In the early 1970s, in a military and international political climate much different than today's, the United States was faced with a shortfall in supplies of petroleum which it was unable to satisfy with domestic sources. The gasoline supply situation was particularly visible and 
acute, but the electric power industry, which had increased petroleum consumption by $600 \%$ between 1963 and 1973, also was seeking reliable domestic oil sources. In an attempt to ensure alternatives to imported oil, a national decision was made to pursue direct coal liquefaction, among other options, as a means to produce domestic supplies of transportation and utility fuels.

The major oil companies (Exxon, Mobil, Chevron, Amoco, Conoco, Gulf and others) and the electric power industry (notably EPRI and Southern Company) actively supported this decision as evidenced by their substantial investment in the development and demonstration of direct liquefaction technology. The majority of the funding in the Phase I direct liquefaction program of the 1970s and early 1980s was focused on large projects to develop and demonstrate the Exxon Donor Solvent (EDS), the HRI H-Coal and SRC-II distillate fuels processes, and the Solvent Refined Coal (SCR) boiler fuel process.

Concurrently, a much smaller, but significant amount of funding was directed to the universities, private sector and government labs which conducted more fundamental research to determine if better alternatives to the high temperature thermal/catalytic processes like EDS and $\mathrm{H}$-Coal could be identified for further development. This work involved substantial research on the chemistry of coal and associated products.

While the $\mathrm{H}$-Coal and EDS programs demonstrated the technical and engineering feasibility of direct coal liquefaction, many issues were not satisfactorily resolved, including those of process yield, selectivity, product quality, and, ultimately, economic potential. However, process development research had identified a number of options for process improvement that were further developed and demonstrated at the bench and pilot plant scale, principally at Lummus-Crest, HRI (later, HTI) and the Wilsonville facility, during the 1980s and early 1990s. This Phase II development work successfully addressed the outstanding technical issues identified earlier, and largely optimized the process in terms of the most important performance parameters. The principal accomplishments of the program are described below. 


\section{High Yields of Distillate Fuels Demonstrated}

One of the most important accomplishments of the Phase II work was a substantial increase in liquid yields compared to the Phase I processes. High liquid yield is important, because direct liquefaction is capital-intensive. Therefore, increasing liquid yields greatly reduced the capital cost component of the process on a dollars/barrel/stream day basis. As shown below, liquid fuel yields were increased from $45 \%$ to $50 \%$ (MAF coal basis) for Phase 1 processes to about $75 \%$ (more than $4.5 \mathrm{bbl} / \mathrm{t}$ of MAF coal) for Phase 2 processes, while the yields of less valuable gaseous and non-distillate fuels were reduced commensurately, as shown below for mid-western U.S. (Illinois Basin) coal.

$\frac{\text { Process }}{\text { Year }}$
Yield, wt \% MAF Coal
Heterogases
$\mathrm{C}_{1}-\mathrm{C}_{3}$ gas
naphtha
middle distillate
gas oil
total distillate
$\mathrm{H}$ consumption, wt \%
$\mathrm{H}$ efficiency, lb dist./lb H consumed
${ }^{*} \mathrm{C}_{1}-\mathrm{C}_{4}$ gas

\begin{tabular}{|c|c|c|c|c|}
\hline SRC-II & H-Coal & EDS & ITSL & CMSL \\
\hline 1980 & 1981 & early $80 \mathrm{~s}$ & 1989 & $\overline{1994}$ \\
\hline 12.9 & 11.3 & 17.4 & 15.2 & 15.2 \\
\hline 14.5 & 12.8 & $19.0^{*}$ & 5.4 & 11.4 \\
\hline 19.3 & 22.9 & 22.8 & 14.5 & 20.7 \\
\hline 25.2 & 20.0 & 17.0 & 21.7 & 39.1 \\
\hline 4.9 & 7.6 & 4.4 & 29.6 & 12.5 \\
\hline 47.3 & 50.5 & 44.2 & 65.8 & 72.3 \\
\hline 5.0 & 6.0 & 5.9 & 6.0 & $7 . !$ \\
\hline 9.5 & 8.4 & 7.5 & 11.0 & 9. \\
\hline
\end{tabular}

\section{High-Quality Liquids Produced}

The liquids made in the Phase I processes were intended to be crude oil replacements, but they were unstable, highly aromatic, and had high heteroatom (sulfur, nitrogen, oxygen) contents. This prompted concern about refinability, storage stability, and human health, principally related to carcinogenicity. In the Phase II work, considerable attention was paid to improving liquid fuel quality. The Phase II process produces liquid fuels containing no resid, no metals, and very low levels of heteroatoms. These primary products can be refined in conventional refineries to meet current specifications for motor and turbine fuels. Product quality evaluations, which were an important element of the Phase II work, ensured that acceptable transportation fuels can be produced by direct coal liquefaction. The Phase 2 processes make a superb quality naphtha that can be processed in conventional refineries into high-quality gasoline. No undesirable blending interaction with conventional gasolines 
and naphthas is expected. Direct coal liquefaction middle distillates can serve as blend stocks for the production of diesel fuel and kerosene. The higher hydrogen contents of Phase 2 process products alleviate the carcinogenicity concerns related to Phase 1 process products. The properties of naphthas generated by Phase 1 and Phase 2 processes are compared below.

\begin{tabular}{|c|c|c|c|c|c|}
\hline \multirow[b]{2}{*}{ Process } & \multicolumn{4}{|c|}{ Illinois Basin Coal } & \multirow{2}{*}{$\begin{array}{l}\text { PRB Coal } \\
\text { On-line } \\
\text { Hydrotreater } \\
\text { CMSL }\end{array}$} \\
\hline & SRC-II & H-Coal & EDS & CMSL & \\
\hline Year & $\overline{1980}$ & $\overline{1981}$ & late 70 s & $\overline{1996}$ & $\overline{1996}$ \\
\hline \multicolumn{6}{|c|}{ Naphtha Properties } \\
\hline b. pt., EF & $100-400$ & $180-380$ & 158-392 & i.b.p.-350 & $70-350$ \\
\hline EAPI & 39 & 35 & 31.1 & 49.9 & 53.5 \\
\hline $\mathrm{H}$, wt $\%$ & 11.5 & 11.6 & 10.9 & 14.0 & 14.7 \\
\hline S, wt \% & 0.2 & 0.2 & 0.5 & 0.04 & 0.02 \\
\hline $\mathrm{N}$, wt $\%$ & 0.4 & 0.31 & 0.2 & 0.02 & 0.002 \\
\hline O, wt \% & 3.9 & 3 & 2.8 & 0.3 & $<0.1$ \\
\hline
\end{tabular}

\section{Process Scale-Up Demonstrated}

The Phase I work demonstrated successful continuous operation of plants as large as $200 \mathrm{t} / \mathrm{d}$ of coal feed. The Phase II processes are sufficiently similar to the Phase I processes, in terms of process equipment and unit operations, that this experience is directly applicable. In addition, some of the key process equipment, such as the ebullatedbed reactor, is used in petroleum refineries around the world. Materials of construction and equipment designs were found to overcome corrosion, erosion, and fouling problems experienced in Phase 1 plants; these new materials and designs were demonstrated to be suitable. As a result, we can approach the scale-up of the Phase II processes to commercial scale with reasonable confidence. Some specific issues that were originally problem areas, but that were overcome by improved materials, equipment, or process design during the development program include:

- Deashing

- Product compatibility with conventional fuels

- Let-down valve erosion

- Preheater coking

- Corrosion in distillation columns 
This list is illustrative, rather than comprehensive.

\section{Direct Liquefaction Shown to Apply to a Wide Range of Coals}

Lignite, subbituminous, and bituminous coals from the eastern, mid-western, and western U.S. were shown to be suitable feedstocks. These represent the vast majority of U.S. coal resources. One important development was the application of direct liquefaction to low rank coals. In the 1970s, it was generally believed that subbituminous coal was an inferior liquefaction feedstock because of its high oxygen content, and perceived lower reactivity. One emphasis of the Phase II work was to apply direct liquefaction to low-rank coals. This is important, because it proved that the huge reserves of inexpensive western U.S. subbituminous coals make excellent liquefaction feedstocks. The Phase 2 work showed that direct liquefaction is a flexible process. It was shown that direct liquefaction could be applied to a mixed feedstock containing coal and petroleum resids, heavy oil, or bitumen ("coprocessing"), and to coal and waste polymers. This allows a single plant to operate with the most economical feedstock available at a given place and time. The improvement in liquid yields of the Phase 2 processes, relative to Phase 1 processes, with U.S. Powder River Basin subbituminous coal is shown below.

\begin{tabular}{lrrr}
$\frac{\text { Process }}{\text { Year }}$ & H-Coal & & ALC/CMSL \\
\cline { 1 - 2 } Yield, wt \% MAF Coal & 1980 & & 1996 \\
Heterogases & 19.8 & 21.3 \\
$\mathrm{C}_{1}-\mathrm{C}_{3}$ gas & 11.0 & 12.4 \\
naphtha & 24.3 & 23.0 \\
middle distillate & 14.5 & 9.7 \\
gas oil & 11.9 & 33.4 \\
total distillate & $\mathbf{5 0 . 7}$ & $\mathbf{6 6 . 1}$ \\
H consumption, wt \% & 5.6 & 6.8 \\
H efficiency, lb dist./lb H consumed & $\mathbf{9 . 0}$ & $\mathbf{9 . 7}$
\end{tabular}

\section{Economic Competitiveness Was Significantly Improved}

Table 2-1 shows the economic analysis of conceptual full-scale plant designs employing three levels of technological development. The plants have been analyzed on the basis of a common set of economic assumptions shown below. 
Return on Equity (ROE)

$\%$ Equity

Loan Interest (16 Yrs)

Construction Period, Yrs
$15 \%$

$25 \%$

$8 \%$

4
Federal Tax Rate

State/Local Property Tax

Depreciation, DDB, Yrs
$34 \%$

$1 \%$

16

All plants employ Illinois 6 coal. The first design, designated $\mathrm{H}$-Coal, is based on an analysis by process developers in $1981 .{ }^{1}$ Capital required for a first of a kind plant employing $\mathrm{H}$-Coal technology was estimated at $\$ 3.258$ billion $\$ 1981$. We have reduced this figure by $15 \%$ to reflect an Nth plant consistent with the other estimates in Table 2-1.

The second plant, designated ITSL is based on a detailed preliminary design prepared for DOE by Bechtel in 1991-92. ${ }^{2}$ Performance assumed in that study was derived from test results from run 257 at the Wilsonville Pilot Plant.

The plant designated as CMSL is based on bench scale results at Hydrocarbon Technology Incorporated (HTI). Capital and operating costs are based on preliminary designs prepared by $\mathrm{HTI}$ in $1997 .^{3}$ The HTI design use natural gas as a feedstock for some hydrogen production. The design has been modified for coal only input in order to be compatible with the other plants.

Table 2-1 shows that the Required Selling Price (RSP) of direct liquefaction products on an equivalent crude basis to be about $\$ 64, \$ 38$, and $\$ 32$ per barrel for H-Coal, ITSL, and CMSL respectively. Figure 2-1 shows the contribution of coal, O\&M, and capital related charges to the total RSP.

The principal advantage of ITSL vs. H-Coal stems from the substantial increase in yield per ton of coal processed. This, plus improvements in gasification and gas treatment, results in an improvement in yield of about $20 \%$ while reducing capital costs by over $5 \%$. Capital cost per daily barrel was reduced from $\$ 91,800$ to $\$ 61,400$ (in 1999 dollars).

CMSL technology permits a further reduction in capital cost per daily barrel to $\$ 56,600$. Some additional savings would result if the plant were scaled to the higher coal input of the 
other plants shown. CMSL employs less complex reactors and has much reduced catalyst costs. Total catalyst and chemical costs are less than $\$ 500$ /daily barrel of capacity vs. $\$ 1,160$ for the Bechtel ITSL design. The major advantage of CMSL is improved product quality. Syncrude quality considerations are discussed below.

Table 2-2 compares the quality of syncrudes from the three configurations to a typical U.S. crude oil. $\mathrm{H}$ coal liquids were characterized by low hydrogen content and other limitations noted earlier in this report. These limitations counterbalanced their advantage of being all distillate materials that produced a considerable volume gain when refined. The assessment in Table 2-2 that they had a value to refiners equal to crude (e.g. premium of 1.0) may be optimistic.

ITSL products are more similar to petroleum and thus more easily processed. The premium of 1.07 relative to crude oil was determined by Bechtel through extensive refining analysis using the PIMs model.

CMSL liquids contain no residual material and only limited amounts of material boiling above $750 \mathrm{EF}$. The premium value of 1.2 relative to crude was assessed by HRI in the referenced study.

\section{Production of Higher Value Chemical Co-Products Demonstrated}

Direct coal liquefaction is particularly well suited to the co-production of certain chemicals, many of which preserve the inherent molecular structure of the original coal. The production of cresylics, paraffin wax, sulfur (or sulfuric acid), and ammonia co-products were demonstrated. The Phase 2 process operated with subbituminous coal can yield $9 \% \mathrm{MAF}$ of mixed cresylics (valued at $\$ 0.55 / \mathrm{lb}$ ) and $4 \% \mathrm{MAF}$ of paraffin wax (valued at $\$ 0.37 / \mathrm{lb}$, fully refined). Benzene, toluene, BTX, other aromatics, argon, krypton, nitrogen, and other specialty chemicals also can be co-produced with liquid fuels. A coal liquefaction plant

dedicated to producing chemicals, rather than fuels, and integrated into an IGCC plant could be operated at less severe conditions and at substantially less cost than a stand-alone 
liquefaction plant. This suggests the possible inclusion of a direct liquefaction module in a Vision 21 facility.

\section{Benefits Derived from Fundamental Research Program}

A research program, conducted concurrently with the Phase 1 and Phase 2 development programs, evaluated novel process concepts and the fundamental chemistry of coals and catalysts and developed suitable analytical methodology. This program led to better understanding of the process. Some of this understanding, such as the benefits of slurry catalysis, was incorporated in the process development effort that generated the Phase 2 process. This work was sufficiently extensive to conclude that the catalytic/thermal direct liquefaction process, as developed with DOE, is the best liquefaction pathway, and that radical departures are unlikely to result in substantially improved processes Thus, much of the value in the work was in providing indirect confirmation that the process development was optimum. The analytical techniques, catalyst development, and catalyst testing methodologies have spin-off value in that they are being applied in other fields or are likely to be in the future.

\section{CONCLUSIONS}

The DOE direct liquefaction program produced a surprisingly mature technology. The intensive effort between 1976 and 1982 (Phase I), when 90\% of the program funds were expended, resulted in a demonstration of the technical feasibility of the major process components. The Phase I processes, however, were deficient in terms of product yield and quality. This stimulated further research and development work between 1983 and 1999 (Phase II). The Phase II work was significantly less costly than the earlier demonstration projects, but resulted in substantial improvements in process performance and economics. It now is possible to produce liquids of high quality at yields that approach the theoretical maximum. At the same time, the cost for a barrel of product dropped by $50 \%$, because of process optimization and increased yields. Economic and engineering studies conducted throughout Phase II have reduced the uncertainty and, therefore, the risk associated with commercial deployment of the technology. Many ideas for improving the basic thermal/catalytic process were identified and evaluated. Some of these were incorporated 
into the process development effort. In addition, considerable research was directed toward a better fundamental knowledge of coal chemistry, and to identify and explore novel liquefaction concepts distinct from the thermal/catalytic processes. The knowledge gained in the fundamental investigations is valuable in assuring that direct liquefaction technology, as it has been developed, represents a likely optimum in terms of process performance and costs. This knowledge would not have been available without the persistent advances in the technology achieved in the DOE direct liquefaction program.

The current technology is well defined in terms of cost and performance. It represents a technically available option for the production of liquid fuels. It can be used domestically in the United States to limit our exposure to oil price increases in the international market or to offset supply reductions. It also can be used by other nations who choose to use domestic coal to meet their transportation fuel needs, thus reducing demands on conventional petroleum sources. It can be used with coal alone, or to co-process a variety of lower value feedstocks. The results of the DOE program allow direct coal liquefaction to be accurately assessed in context to the costs and risks associated with other options for securing liquid fuel supplies should the need arise.

The future of energy supply and energy costs is uncertain. The recent increase in petroleum and natural gas prices serves as a timely reminder of our inability to forecast even shortterm trends. We now rely on foreign sources for nearly $60 \%$ of our petroleum, a greater percentage than in the 1970s. In addition, natural gas imports increased for 13 consecutive years. Since 1990, natural gas imports have doubled and now account for $17 \%$ of our natural gas consumption. In contrast to the situation with oil and natural gas, coal is the most stable and abundant fossil energy resource in the United States, and much of the rest of the world. The DOE direct coal liquefaction program represents a prudent investment to mitigate of the risk of future increases in petroleum prices or curtailment of supplies for economic or political reasons. 


\section{References for Chapter 2}

1. Ashland Synthetic Fuels, Inc. and Airco Energy Company, Inc., The Breckinridge Project Initial Effort Report VIII, prepared for U.S. DOE under Cooperative Agreement No. DE-FC05-800R, 1981.

2. Bechtel Corporation, Final Report on Baseline and Improved Baseline Volume VIII, Design, Capital Cost, and Economics For Improved Baseline, Contract No. DEAC22 90PC89857, March 1993.

3. Hydrocarbon Technologies, Inc., Direct Liquefaction Proof of Concept Program, DE92148-TOP-09,Contract No. AC22-92PC92148, December 1997.

Table 2-1. Economics of Coal Liquefaction

\begin{tabular}{|c|c|c|c|c|c|c|c|}
\hline & \multicolumn{2}{|c|}{ H-Coal } & \multicolumn{2}{|c|}{ ITSL } & \multicolumn{3}{|c|}{ CMSL } \\
\hline & $\$ 1981$ & $\$ 1999$ & $\$ 1991$ & $\$ 1999$ & $\$ 1994$ & $\$ 1999$ & $\$ 1999$ \\
\hline Hydrogen Source & Coal & Coal & Coal & Coal & $N G$ & $N G$ & Coal \\
\hline Yield, bbls/day & 50,000 & 50,000 & 69,000 & 69,000 & 51,500 & 51,500 & 51,500 \\
\hline Coal Feed T/D AR & 26,370 & 26,370 & 25,415 & 25,415 & 13,400 & 13,400 & 18,090 \\
\hline @ \$/Ton AR & 20.5 & 20.5 & 20.5 & 20.5 & 20.5 & 20.5 & 20.5 \\
\hline $\begin{array}{l}\text { Plant Cost \$MM } \\
\text { Escalation Factor }\end{array}$ & $\$ 2,769$ & $\begin{array}{r}\$ 4,592 \\
1.658\end{array}$ & $\$ 3,543$ & $\begin{array}{r}\$ 4,239 \\
1.197\end{array}$ & $\$ 2,481$ & $\begin{array}{r}\$ 2,714 \\
1.094\end{array}$ & $\$ 2,914$ \\
\hline Capital Cost $/ @ \$ M M / Y r$ & $\$ 415$ & $\$ 689$ & $\$ 531$ & $\$ 636$ & $\$ 372$ & $\$ 407$ & $\$ 437$ \\
\hline $\begin{array}{l}\text { Coal Cost, } \$ M M y r \\
\text { Natural Gas } \$ M M / y r\end{array}$ & $\$ 178$ & $\$ 178$ & $\$ 172$ & $\$ 172$ & $\begin{array}{l}\$ 91 \\
\$ 71\end{array}$ & $\begin{array}{l}\$ 91 \\
\$ 71\end{array}$ & $\$ 122$ \\
\hline $\mathrm{O} \& \mathrm{M} / \mathrm{Yr}, \$ \mathrm{MM} / \mathrm{Yr}$ & $\$ 111$ & $\$ 184$ & $\$ 115$ & $\$ 138$ & $\$ 74$ & $\$ 81$ & $\$ 87$ \\
\hline Total Cost/Yr & $\$ 705$ & $\$ 1,051$ & $\$ 819$ & $\$ 946$ & $\$ 609$ & $\$ 651$ & $\$ 647$ \\
\hline MMbbls/Yr & 16.50 & 16.50 & 22.77 & 22.77 & 17.00 & 17.00 & 17.00 \\
\hline RSP & $\$ 42.70$ & $\$ 63.69$ & $\$ 35.95$ & $\$ 41.53$ & $\$ 35.81$ & $\$ 38.28$ & $\$ 38.06$ \\
\hline Premium & 1.00 & 1.00 & 1.07 & 1.07 & 1.20 & 1.20 & 1.20 \\
\hline EqCrude RSP & $\$ 42.70$ & $\$ 63.69$ & $\$ 33.60$ & $\$ 38.81$ & $\$ 29.90$ & $\$ 31.96$ & $\$ 31.78$ \\
\hline Capital/Barrel/Day & & $\$ 91,841$ & & $\$ 61,439$ & & & $\$ 56,580$ \\
\hline
\end{tabular}

Table 2-2. Properties of Syncrude and Typical Crude

\begin{tabular}{lrrrr} 
& H-Coal & \multicolumn{1}{c}{ ITSL } & CMSL & Typ. Crude \\
Carbon & 86.63 & 85.72 & 86.57 & 85.80 \\
Hydrogen & 10.54 & 11.48 & 13.08 & 13.00 \\
Nitrogen & 0.50 & 0.49 & $44 \mathrm{ppm}$ & $2000 \mathrm{ppm}$ \\
Sulfur & 0.19 & 0.07 & 0.06 & 1.00 \\
Oxygen & 2.13 & 2.24 & 0.44 & \\
Vanadium & nil & nil & nil & 200 ppm \\
\%650 EF & 83 & 79 & 80 & 53 \\
$\% 975 \mathrm{EF}^{+}$ & 0 & 0 & 0 & 20 \\
API Gravity & 27 & 22 & 38 & 32 \\
Premium & 1.00 & 1.07 & 1.20 & 1.00
\end{tabular}




\section{Chapter 3}

\section{SRC-II PROCESS ${ }^{1}$}

\section{R. A. Winschel, CONSOL Energy Inc.}

\section{BACKGROUND}

The SRC-II process was, to a great extent, an outgrowth of the earlier Solvent Refined Coal (SRC) process, which had been under development since 1962 by Spencer Chemical Co.; Gulf Oil Corp., after its purchase of Spencer in 1963; and, beginning in 1966, by the Office of Coal Research (Contract No. 14-01-0001-496) and Pittsburg \& Midway Coal Mining Co., a Gulf subsidiary. The SRC development progressed through bench-scale autoclave work at the Merriam, KS, facility and a $1 \mathrm{t} / \mathrm{d}$ PDU in Kansas City, MO, and culminated in the operation of the $50 \mathrm{t} / \mathrm{d}$ Ft. Lewis, WA, pilot plant beginning in 1974. The SRC process was designed to produce from coal an ash-free, reduced sulfur-content boiler fuel that was solid at room temperature but melted at elevated temperatures of about $350 \mathrm{EF}$. The SRC process is shown schematically in Figure 3-1. Coal is slurried with a recycled distillate process solvent, and the slurry is mixed with hydrogen gas, then heated to and held at reaction temperature. Gases are separated from the reaction products, which are then filtered to remove the solids (mineral matter and undissolved coal), and the solvent for recycle is stripped from the filtered products. The stripped, filtered reaction product is the SRC product.

As the SRC process was being developed by the government and P\&M during the late 1960s and early 1970s, Gulf Oil independently was developing a proprietary higher-severity coal liquefaction process. Several small pilot plants were operated, and in 1976, a $0.5 \mathrm{t} / \mathrm{d}$ PDU known as the P-99 unit in Harmarville, PA, began operating with private funding in what came to be known as the SRC-II mode. The Ft. Lewis pilot plant was modified to run in the SRC-II mode in 1977. In 1978, work on the P-99 PDU was put under contract to DOE (contract DE-AC05-78OR03055) to support the Ft. Lewis pilot plant efforts, and in 1979, various related $R \& D$ activities at Harmarville were added to the DOE programs. The work at Merriam was redirected toward exploratory work under DOE contracts DE-AC22- 
79ET14800 and -81PC40005. The exploratory work at Merriam continued for some time after the pilot plant and PDU programs ceased in 1981. From 1979 until the project terminated, the Ft. Lewis pilot plant was used to test and develop hardware and equipment, evaluate materials of construction, demonstrate operability with a variety of coals, and produce large quantities of product for testing; the P-99 PDU was used for process engineering and process performance studies, and the Harmarville laboratory was used for supporting R\&D. Over time, the original OCR contract evolved through ERDA contract E(49-18)-496 and DOE contract EX-76-C-01-0496 and into DOE contract DE-AC0579ET10104. Activities at both the Ft. Lewis pilot plant and the P-99 PDU were terminated in mid-1981 with the expiration of the DOE contract.

The SRC-II process is shown schematically in Figure 3-2. The main differences from the SRC process include: 1) The recycle solvent in SRC-II is stripped reactor effluent slurry containing primarily non-distillable residue and solids, rather than a middle distillate (b.p. 480-850 EF) as in SRC. This difference favors production of distillates; 2) reaction pressure was increased from 1500 to 2000 psig; 3) space velocity was reduced; 4) solids were not separated from the bottoms, which were produced to be gasifier feed in SRC-II, rather than the primary product in SRC. This change gives additional residence time to organic solids and allows recycle of natural or added catalysts. SRC-II was designed to produce distillable liquids, rather than a clean solid, as the primary products. In concept, the yield of non-distillable organic products (SRC and insoluble organics) would be sufficient, but not overly sufficient, to generate feedstock for a gasifier to generate process hydrogen requirements.

A $\$ 1.5$ billion, $6000 \mathrm{t} / \mathrm{d}$ demonstration plant $^{2}$ (Figure 3-3) was planned by a consortium of Gulf, DOE, and the governments of West Germany and Japan. The plant was to be located north of Morgantown, WV, on the Monongahela River. The estimated product yields from that plant (in bbl/d) were: pipeline gas, 1670; liquid propane, 2320; naphtha, 3850; fuel oil, 8350; and the estimated byproduct yields (in t/d) were: sulfur, 200; ammonia, 30; tar acids, 7. Representatives of the U.S., West Germany, and Japan met in June 1981 and agreed to cancel the project ${ }^{3}$ before the demonstration plant was constructed. 


\section{ACCOMPLISHMENTS}

\section{Process Operability Demonstrated}

Numerous continuous bench-unit and pilot-plant tests demonstrated the operability of the SRC-II process. These tests also were used to obtain databases on process performance and product/process stream properties for scale-up design, to evaluate a wide range of operating conditions, to test seven different feed coals (includes pilot plant and PDU) and to develop predictive equations to screen candidate coals, and to evaluate sources of disposable catalysts for unreactive coals.

\section{Process Operating Conditions Selected and Yields Demonstrated}

Material balance runs were conducted at the Ft. Lewis pilot plant with the following coals: Western Kentucky Nos. 9 and 14 (Colonial Mine), Illinois 6 (River King Mine), Pittsburgh seam (from both the Blacksville 2 and Powhatan 5 Mines). The principal operating variables for the 30 material balance runs were set within the following ranges or maxima:

$\begin{array}{ll}\text { Operating Variable } & \text { Range or Maximum } \\ \text { coal concentration in feed slurry } & 20-35 \mathrm{wt} \% \\ \text { recycle solids plus coal concentration } & 48 \mathrm{wt} \% \text {, max. } \\ \text { dissolver residence time } & 0.75-1.0 \mathrm{~h} \\ \text { dissolver temperature } & 835-870^{\circ} \mathrm{F} \\ \text { dissolver pressure } & 2000 \mathrm{psig}, \text { max. } \\ \text { feed hydrogen purity } & 80-90 \%\end{array}$

These variables (including coal type) were chosen because studies at the P-99 and Merriam facilities indicated they were the principal variables influencing product yield. The operating constraint was to produce sufficient vacuum bottoms to generate, in theory, the hydrogen and fuel syngas needs of the process via gasification of the bottoms. Within this constraint, the intent was to maximize liquid yield, with fuel oil (middle distillate plus heavy distillate) being the primary plant product. The mean process yields (wt \% MAF coal basis) for the 
four coals from material balance runs at all conditions follow (the reference ${ }^{1}$ did not provide mean yields of naphtha or heterogases).

\begin{tabular}{|l|c|c|c|c|}
\hline \multicolumn{1}{|c|}{ Product Fraction } & $\begin{array}{c}\text { W. Kentucky } \\
\mathbf{9 / 1 4} \text { Seams }\end{array}$ & $\begin{array}{c}\text { Illinois } \mathbf{6} \\
\text { Seam }\end{array}$ & $\begin{array}{c}\text { Blacksville 2 } \\
\text { Mine }\end{array}$ & $\begin{array}{c}\text { Powhatan 5 } \\
\text { Mine }\end{array}$ \\
\hline C1 - C4 gas & 16.3 & 13.8 & 15.8 & 17.8 \\
\hline Fuel Oil & 29.7 & 32.4 & 27.5 & 32.9 \\
\hline SRC (900 EF solubles) & 28.1 & 27.2 & 33.2 & 28.5 \\
\hline Insoluble Organics & 6.4 & 5.7 & 10.8 & 6.0 \\
\hline H consumption & 4.2 & 4.4 & 4.0 & 4.6 \\
\hline
\end{tabular}

Material balance runs with the four coals at similar operating conditions $(29-30 \%$ coal concentration, 852-861 EF dissolver temperature, 1920-2017 psig dissolver pressure, and 0.96- $0.99 \mathrm{~h}$ residence time) gave the following yields ( $\mathrm{wt} \%$, MAF coal basis, the reference ${ }^{1}$ did not provide heterogas yields, which are calculated by difference here).

\begin{tabular}{|l|r|r|r|r|}
\hline \multicolumn{1}{|c|}{$\begin{array}{c}\text { Product } \\
\text { Fraction }\end{array}$} & \multicolumn{1}{|c|}{$\begin{array}{c}\text { W. Kentucky } \\
\mathbf{9 / 1 4} \text { Seams }\end{array}$} & Illinois 6 Seam & $\begin{array}{c}\text { Blacksville 2 } \\
\text { Mine }\end{array}$ & $\begin{array}{c}\text { Powhatan 5 } \\
\text { Mine }\end{array}$ \\
\hline $\mathrm{C}_{1}-\mathrm{C}_{4}$ gas & 18 & 16 & 13 & 17 \\
\hline heterogases & 12 & 15 & 6 & 9 \\
\hline naphtha & 15 & 16 & 9 & 6 \\
\hline Fuel Oil & 28 & 31 & 26 & 38 \\
\hline SRC & 26 & 23 & 38 & 29 \\
\hline IOM & 6 & 5 & 11 & 5 \\
\hline H consump. & 4.8 & 4.6 & 3.4 & 4.2 \\
\hline
\end{tabular}

Additional Pittsburgh Seam coals (Powhatan 6, Valley Camp, and Ireland Mines) also were tested at the P-99 Unit. Correlations between yields and coal properties developed at the P-99 Unit showed that higher sulfur content, reactive maceral content, and hydrogen/ carbon ratio of the coal favor liquid yield and reduce IOM yield. On the basis of these correlations, the impact of coal cleaning was evaluated ${ }^{4}$ for Ireland and Powhatan Mine coals. Coal 
cleaning reduces sulfur content but affects maceral content and $\mathrm{H} / \mathrm{C}$ ratio very little; thus, the model predicted that coal cleaning would reduce the liquid yield on a MAF basis for these coals (although partially cleaned and deep-cleaned coals would give higher liquid yields on a dry coal basis). Process operating conditions and process yields from a single, representative Ft. Lewis material balance run with Illinois Basin coal are shown in Chapter 2. An analysis of random errors in the material balance yields showed the following $95 \%$ confidence interval for the product yields: naphtha (nominally ibp-350 EF), $\pm 20 \%$; middle distillate (nominally $350-550 \mathrm{EF}$ ), $\pm 22 \%$; heavy distillate (nominally $550-850 \mathrm{EF}$ ), $\pm 51 \%$; total distillate, $\pm 10 \%$.

\section{Product Quality, Testing, Upgrading, and Toxicity}

Naphtha

SRC-II raw naphtha is highly aromatic and naphthenic, which may be desirable qualities in a gasoline blendstock or reformer feedstock. However, the raw naphtha also has high concentrations of sulfur $(0.24 \%)$, nitrogen $(0.88 \%)$, and oxygen $(3 \%)$, and the material is unstable in that it forms solids and gums upon storage. These features indicate that substantial upgrading would be required for either use. UOP ${ }^{5}$ demonstrated that SRC-II naphtha can be hydrotreated to make an acceptable reformer feedstock. The reformate produced from the hydrotreated naphtha is very highly aromatic.

\section{Fuel Oil}

SRC-Il fuel oil is produced by blending the middle distillate and heavy distillate, typically in a ratio of 2.9/1. Early SRC-II tests produced a much higher ratio of the two streams, as high as $6 / 1$, but this is not considered characteristic of the process. The fuel oil differs from petroleum fuel oil in important ways. In the following list of SRC-Il fuel oil properties, a superscript "a" indicates the value represents a $5 / 1$ or $5.75 / 1$ ratio product, and a superscript "b" indicates the value represents a 2.9/1 product. The SRC-II fuel oil has an attractively low pour point $\left(-54 \mathrm{EF}^{\mathrm{a}}\right)$ and reasonably low sulfur content $\left(0.24 \%^{\mathrm{b}}\right)$, but it has high nitrogen content $\left(0.9 \%^{\mathrm{b}}\right)$, high oxygen content $\left(4.5 \%^{\mathrm{a}}\right.$, due to phenols), low hydrogen content $\left(8.8 \%^{\mathrm{a}}\right)$, and a relatively low volumetric heating value $\left(5.9 \mathrm{MM} \mathrm{Btu} / \mathrm{bbl}^{\mathrm{b}}\right)$. These qualities indicate that the product is highly aromatic and phenolic. SRC-II middle distillate 
made stable blends with No. 2 fuel oil; however, SRC-Il fuel oil, made by mixing middle distillate and heavy distillate in a 2/1 ratio, was not fully compatible with No. 2 fuel oil ${ }^{6}$. The SRC-II oil also tended to form stable emulsions with water ${ }^{6}$.

\section{Fuel Combustion Testing}

SRC-II fuel oil, produced from a 5.75/1 ratio of middle and heavy distillates, was tested as a boiler fuel at the Consolidated Edison $74^{\text {th }}$ Street Station in New York City. Staged combustion resulted in trouble-free operation, and emissions were within all applicable regulations. $^{7}$ The Massachusetts Institute of Technology also tested a 2.9/1 blend containing $0.96 \%$ nitrogen in a pilot-scale furnace and reported that staged combustion could effectively reduce NOx emissions without excessive production of carbonaceous particulates. ${ }^{8}$ SRC-II middle distillate was also tested in stationary combustion turbines ${ }^{9}$ and diesel engines ${ }^{10,11}$ with reasonable success. Westinghouse Electric Corp. showed that a $3 / 1$ blend could be fired in a combustion turbine, but that, similar to residual fuel oil, problematic ash deposition occurred at temperatures above $2000 \mathrm{EF}{ }^{12}$ SRC-II products were also evaluated in diesel engines and other combustion apparatus, by researchers from Japan, ${ }^{13,14}$ General Electric, ${ }^{15}$ Babcock and Wilcox, ${ }^{16}$ Cummins,${ }^{17}$ and elsewhere ${ }^{18,19}$

\section{Upgrading}

Chevron evaluated concepts for upgrading SRC-II full-range liquid product. ${ }^{20,21}$ The raw SRC-II liquid was unsuitable for use in a conventional refinery because of its high nitrogen content and aromaticity. High-severity hydrotreating (3000 SCF/bbl hydrogen consumption) resulted in a material that could be fractionated into jet fuel and naphtha suitable for reforming. Moderate-severity hydrotreating (1500 SCF/bbl hydrogen consumption) resulted in a product suitable for producing gasoline and No. 2 heating oil. The jet fuel and naphtha from hydrotreating are both highly naphthenic. It is expected that the hydrotreated naphtha would produce a high-octane reformate in high yield. Chevron's tests confirmed that the jet fuel fraction met all applicable specifications, except that it was too dense. Extensive laboratory hydrogenation investigations were carried out by, for example, the University of Delaware in conjunction with Gulf, ${ }^{22-25} \mathrm{SRI}$ International, ${ }^{26}$ and National Institute for Petroleum and Energy Research. ${ }^{27}$ 


\section{Non-Fuel Alternative Products}

The SRC-II process yields substantial quantities of phenolic compounds. For example, in eight runs with eastern U.S. bituminous coals at the P99 unit, phenolic compounds constituted $10 \%$ to $52 \%$ of the raw product boiling between 55 EC and 260 EC (150 and $500 \mathrm{EF}$ ); ${ }^{28}$ this cut represented about $19 \%$ of the coal fed (MAF, dry, or raw basis not stated in Reference 28 ) and about $50 \%$ of the total liquid product; therefore, the yield of phenolics in the boiling point span ranged from $2 \%$ to $10 \%$ of the coal. In another case, a "typical" SRC-II product contained 25\% phenolics in the 55-249 EC (131-480 EF) cut. ${ }^{28}$ It is conceivable that these phenolics could be separated and sold as a separate non-fuel chemical stream. The large quantity of phenolics produced by SRC-II led Gulf R\&D to examine the possibility of producing methyl phenyl ethers from them. ${ }^{28}$ Methyl phenyl ethers are high-octane oxygenates that could serve as gasoline extenders. For Gulf's tests, the ethers were produced from the phenolics extracted in $29 \%$ yield from a composite SRC-II product boiling in the range 55 to $260 \mathrm{EC}$ (150 to $500 \mathrm{EF}$ ) from 51 liquefaction runs with eastern U.S. bituminous coals. Gulf's extensive program, which included blending, compatibility, toxicity, octane quality, deposition, drivability, fuel economy, engine wear, oil consumption, and emissions tests with automobiles, showed the ethers to be excellent gasoline blending agents and octane improvers. The potential of SRC-II products being petrochemical, ${ }^{29} \mathrm{BTX},{ }^{30}$ and ethylene ${ }^{31}$ feedstocks were discussed.

\section{Toxicity and Mutagenicity of Products}

Battelle Pacific Northwest Laboratories ${ }^{32}$ evaluated the biological activity of SRC-Il products. As with other coal liquids they evaluated, almost all of the genetic activity is contained in the fractions that boil above 700 EF. SRC-II distillates boiling below 650 EF showed carcinogenic activity (mouse skin) no different than that of crude petroleum. There was no detectable teratogenic activity (in rats) for distillates boiling below $700 \mathrm{EF}$, but teratogenic activity increased at higher boiling points. There was no microbial mutagenicity for distillates boiling below $700 \mathrm{EF}$, but mutagenicity increased sharply with boiling point above $700 \mathrm{EF}$. Mutagenic activity was strongly reduced by hydrogenation. ${ }^{33}$ Other studies of the genotoxicity of SRC-II materials were performed by SRI International. ${ }^{34}$ The acute toxicity ${ }^{35}$ and the effects of inhalation exposure ${ }^{36}$ to SRC-II materials also were evaluated. 


\section{Effectiveness of Iron Liquefaction Catalysts Verified}

The oil yield/coal composition correlations showed that liquid yield correlated with coal sulfur content, presumably a surrogate for pyrite or iron. Work at the Harmarville facility showed that various iron-containing waste materials were active catalysts for increasing liquid yield, even for high-pyrite coals, such as Powhatan 5 and Ireland Mine coals. Fairly high catalyst loadings, $10 \%$ coal basis, were required to obtain $4-8 \%$ increases in liquid yield in the laboratory tests. It was presumed that catalyst loading could be reduced by more than half in continuous SRC-II processing because of the use of solids recycle. Work at the Merriam facility indicated that low-rank coals may be particularly attractive feedstocks for SRC-II processing, if disposable catalysts, such as ground pyrite, can be used. ${ }^{1,37}$

\section{Large Quantities of Products Generated for Further Testing}

The Ft. Lewis pilot plant produced over $3000 \mathrm{bbl}$ of SRC-II fuel oil and over 5000 ton of SRC for test burns and other evaluations. Evaluations included combustion tests in boilers, stationary turbines, and low-speed diesel engines; product upgrading to transportation fuels, tests of bottoms product as gasifier feedstock, and toxicology testing.

\section{Operational and Materials Shortcomings Resolved}

Operations on the continuous bench-units and pilot plant resolved serious coking problems in the vacuum flash system, improved high-pressure slurry pump operability, demonstrated improved materials for erosion and corrosion control and for improved slurry metering, and developed means to avoid chloride stress corrosion cracking of dead-end connections. Alloys for construction of light-end distillation columns that would not corrode were verified. These tests also showed that direct gas quench with $250 \mathrm{EF}$ hydrogen could be used to rapidly and tightly control reactor temperature despite changes in operating conditions. They also demonstrated that the $\mathrm{CO}$ concentration in the recycle gas could be increased to $10 \%$ with no adverse effects on performance and that $\mathrm{CO}$ concentration would not continuously increase in a full-scale plant, because the water-gas shift reaction would be promoted at higher $\mathrm{CO}$ concentrations.

\section{$\underline{\text { References for Chapter } 3}$}


1. The Pittsburg and Midway Coal Mining Co., "Solvent Refined Coal (SRC) Process Final Report" DOE/ET/10104-46 (vols. 1 and 2), May 1982.

2. Freel, J.; Jackson, D. M.; Schmid, B. K. "SRC-II Demonstration Project" Chem. Eng. Prog. 1981, vol. 77, No. 5, 86-91.

3. "Policy Changes Torpedo SRC-II" Chem. Eng. 1981, vol. 88, No. 15, 25.

4. Sood, A. "Heavy Media Separation of SRC-II Feedstocks: 2. Effect on Liquefaction Yields" Fuel 1984, vol. 63, No. 8, 1148-51.

5. Riedl, F. J., DeRosset, A. J. "Hydrotreating and Reforming SRC-II Process Derived Naphtha" FE-2566-77, June 1979.

6. The Pittsburg and Midway Coal Mining Co., "Solvent Refined Coal (SRC) Process" Annual Technical Progress Report for 1978, Report No. FE/496-170.

7. Electric Power Research Institute, Final Report AF-790, Project 779-11, March 1978.

8. Beer, J. M., Jacques, M. T., Hanson, S., Rovesti, W. C. "Reduction of NOx and Particulates Emission By Staged Combustion of Coal Derived Liquid Fuels" in Proceedings of the Sixth Annual EPRI Contractors' Conference on Coal Liquefaction, EPRI Report AP-2079-LD, published October 1981.

9. Gas Turbine Conference and Products Show, ASME Gas Turbine Division, Papers 81-GT108, 81-GT-109, 81-GT-125, and 81-GT-157, Houston, TX, March 1981.

10. "Economic and Technological Assessment of Diesel Engines Using Coal Based Fuels for Electric Power Generation" DOE Contract No. EF-77-C-102647, Report No. TE4234-37-80, September 1979.

11. Pearce, K. R. "SRC-II Fuel Use in Medium Speed Diesel Engines" in Proceedings: Ninth Annual EPRI Contractors' Conference on Coal Liquefaction, EPRI Report AP3825-SR, published March 1985.

12. Cohn, A. "Deposition of Combustion Products of SRC-II Middle-Heavy Blend" in Proceedings of the Sixth Annual EPRI Contractors' Conference on Coal Liquefaction, EPRI Report AP-2079-LD, published October 1981.

13. Katoh, Y.; Shimauchi, T.; Nakagaki, T. "SRC-II in Spark Assisted Multifuel Diesel Engine" SAE Transactions 1984, vol. 93, No. 1, 1.11-1.22.

14. Mori, M.; Arakawa, S. "SRC-II Combustion in Prechamber Diesel" SAE Transactions 1984, vol. 93, No. 1, 1.1-1.10.

15. Pearce, K. R., Jr. "SRC-II Coal-Derived Fuel Utilization in Medium-Speed Diesel Engines" Paper at the 15th Int'l Congress on Combustion engines, Paris, France, 1983, pp 77-101.

16. Downs, W.; Vecci, S. J.; Barsin, J. A.; Rovesti, W. C. "Characterization and Combustion of SRC-II Fuel Oil" J. of Engineering for Power, vol. 102, No. 3, 672-8.

17. Slone, R. J.; Kamo, R. "Utilization of SRC-II Fuel Oil in an Insulated Diesel Engine" DOE Report No. DOE/ET/15450-T29, 1984.

18. Tong, E. H.; Mellor, A. M. "Performance of SRC-II Fuels in Gas Turbine Combustors" in ASTM Spec. Tech. Publication: Stationary Gas Turbine Altern. Fuels, 1983, pp 7997

19. Hoffman, J. G., Jr. "Coal Derived (SRC-II) Fuel in a Medium Speed Diesel Engine: an Investigation" ASME Meeting Paper 1982, paper No. 82-DGP-17.

20. Sullivan, R. F. and Frumkin, H. A. "Processing of SRC-II Syncrude" Third Interim Report under DOE Contract No. EF-76-C-01-2315, Report FE-2315-47, April 1980. 
21. Frumkin, H. A.; Sullivan, R. F.; Strangeland, B. E. "Converting SRC-II Process Product to Transportation Fuel" Fuel Proc. Technol. 1980, vol. 6, 217-9.

22. Katti, S. S.; Gates, B. C.; Petrakis, L. "Catalytic Hydroprocessing of SRC-II Heavy Distillate Fractions 6. Hydroprocessing of the Bases and Neutral Resins" Ind. Eng. Chem. Proc. Des. Dev. 1986, vol. 25, No. 3, 618-26.

23. Grandy, D. W.; Petrakis, L.; Li. C.-L., Gates, B. C. "Catalytic Hydroprocessing of SRC-II Heavy Distillate Fractions 5. Conversion of the Acidic Fractions Characterized by Gas Chromatography/Mass Spectrometry" Ind. Eng. Chem. Proc. Des. Dev. 1986, vol. 25, No. 1, 40-8.

24. Li, C.-L.; Xu, A.-R.; Gates, B. C.; Petrakis, L. "Catalytic Hydroprocessing of SRC-II Heavy Distillate Fractions 4. Hydrodeoxygenation of Phenolic Compounds in the Acidic Fractions" Ind. Eng. Chem. Proc. Des. Dev. 1985, vol. 24, No. 1, 92-7.

25. Katti, S. S.; Sanjeev, S.; Westerman, D. W. B.; Gates, B. C.; Youngless, T.; Petrakis, L."Catalytic Hydroprocessing of SRC-II Heavy Distillate Fractions 3. Hydrodesulfurization of the Neutral Oils" Ind. Eng. Chem. Proc. Des. Dev. 1984, vol. 23, No. 4, 773-8.

26. Hirschon, A. S.; Wilson, R. B.; Laine, R. M. "Catalytic Hydrodenitrogenation of an SRC-II Coal Liquid. Effect of Hydrogen Sulfide" Am. Chem. Soc. Div. Fuel Chem. Prepr. 1985, vol. 30, No. 2, 298-302.

27. Green, J. B.; Grizzle, P. L.; Thomson, J. S.; Hoff, R. J.; Green, J. A. "Composition on an SRC-II Coal-Derived Liquid: Changes in Composition Resulting From Hydrotreatment at Different Levels of Severity" Fuel 1985, vol. 64, No. 11, 1581-90.

28. Singerman, G. M. "Methyl Aryl Ethers From Coal Liquids as Gasoline Extenders and Octane Improvers" Report DOE/CE/50022-1, November 1980.

29. Harris, G. A.; Sinnett, C. E. "SRC-II (Solvent Refined Coal) Is a Promising Petrochem Feedstock Source" Oil and Gas J. 1980, vol. 78, No. 34, 119-23.

30. Sullivan, R. F.; O'Rear, D. J.; Strangeland, B. E. "Catalytic Hydroprocessing of SRCII and H-Coal Syncrudes for BTX Feedstocks" Am. Chem. Soc. Div. Fuel Chem. Prepr. 1980, 25 (3), 583-607.

31. Harris, G. A.; Duckworth, W. C.; Swift, H. E. "SRC-II: a Source of Ethylene" Chem. Eng. Prog. 1982, vol. 78, No. 4, 43-7.

32. Wilson, B. W., Later, D. W. "Chemical Basis for Reduced Biological Activity in Advanced Coal Liquefaction Processes" in Proceedings: Eighth Annual EPRI Contractors' Conference on Coal Liquefaction, EPRI Report AP-3366-SR, published February 1984.

33. Wilson, B. W., Petersen, M. R., Pelroy, R. A., Cresto, J. T. "In-Vitro Assay for Mutagenic Activity and Gas Chromatography-Mass Spectral Analysis of Coal Liquefaction Material and the Products Resulting from Its Hydrogenation" Fuel 1981, vol. 60 289-294.

34. Haykaufman, M.; Mitchell, A. D.; Spanggord, R.; Butala, J. H.; Strother, D. E. "Detection of Genotoxic Activity of SRC-II Materials in the In Vitro Rat Hepatocyte Unscheduled DNA-Synthesis Test" Environmental Mutagenesis 1983, vol 5, No. 3, 462-3.

35. Strother, D. E.; MacFarland, H. N.; Dean, W. P.; Ulrich, C. E.; Jessup, D. C.; Ward, C. O. "Acute Toxicity of Selected Sovent-Refined Coal (SRC-II) Materials" J. Am. College of Toxicology 1983, vol. 2, No. 2, 248. 
36. Springer, D. L.; Miller, R. A.; Weimer, W. C.; Ragan, H. A.; Buschbom, R. L. Mahlum, D. D. "Effects of Inhalation Exposure to SRC-II Heavy and Middle Distillates" Pacific Northwest Laboratory Report PNL-5273, 1984.

37. Alexander, B. F.; Anderson, R. P. "SRC-II Processing of Western Coals With Added Pyrite" Am. Chem. Soc. Div. Fuel Chem. Prepr. 1982, vol. 27, No. 2, 18-27.

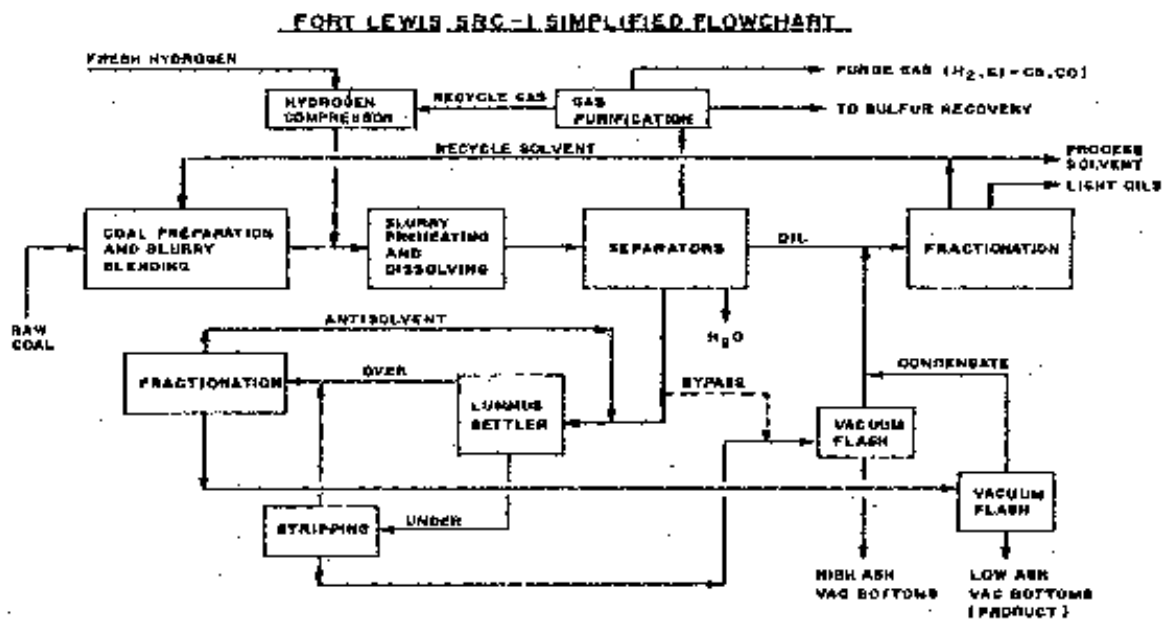

Figure 3-1. SRC Process Schematic.

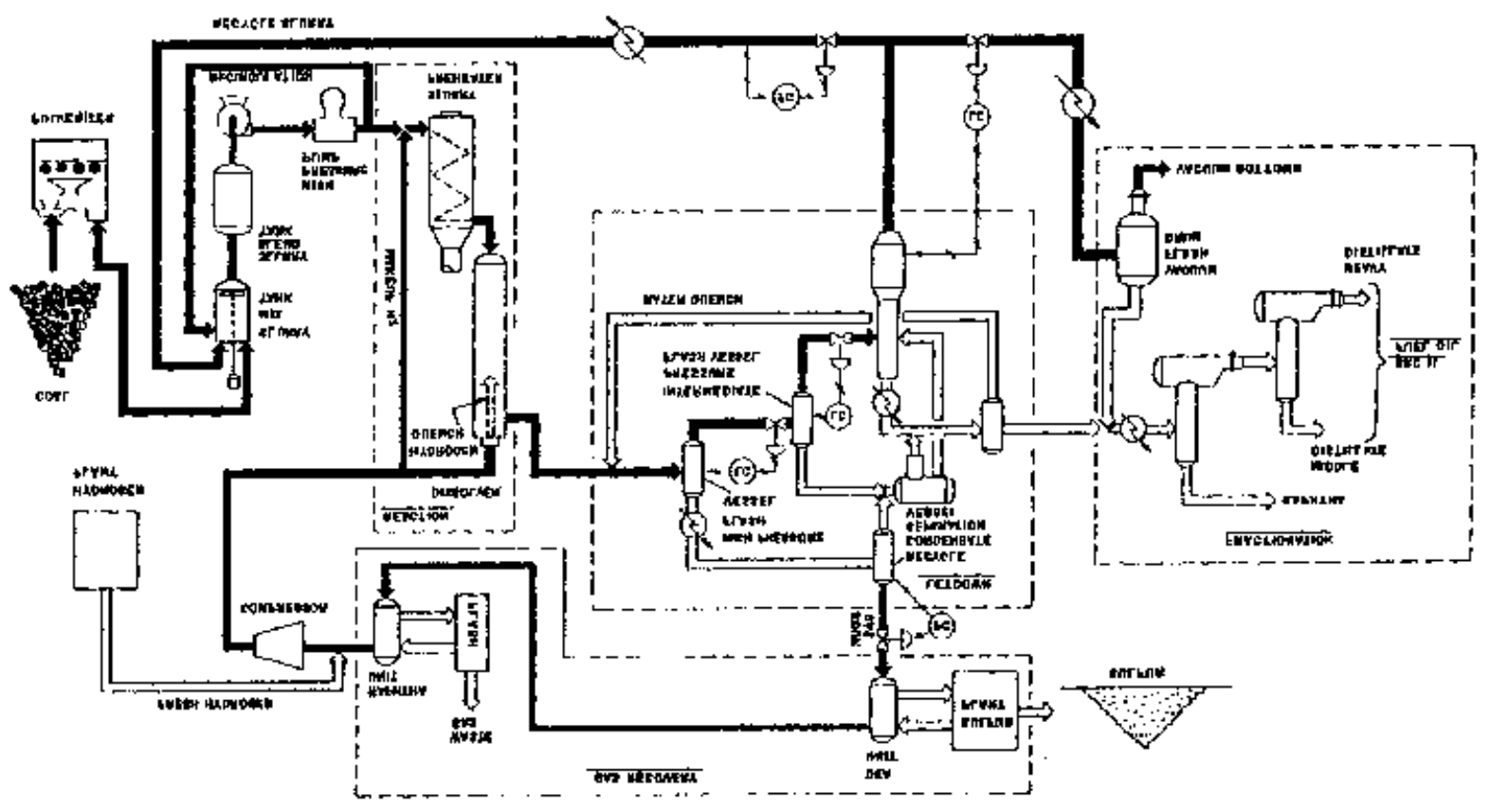

Figure 3-2. Schematic Process Flow Diagram of Fort Lewis SRC II Pilot Plant. 


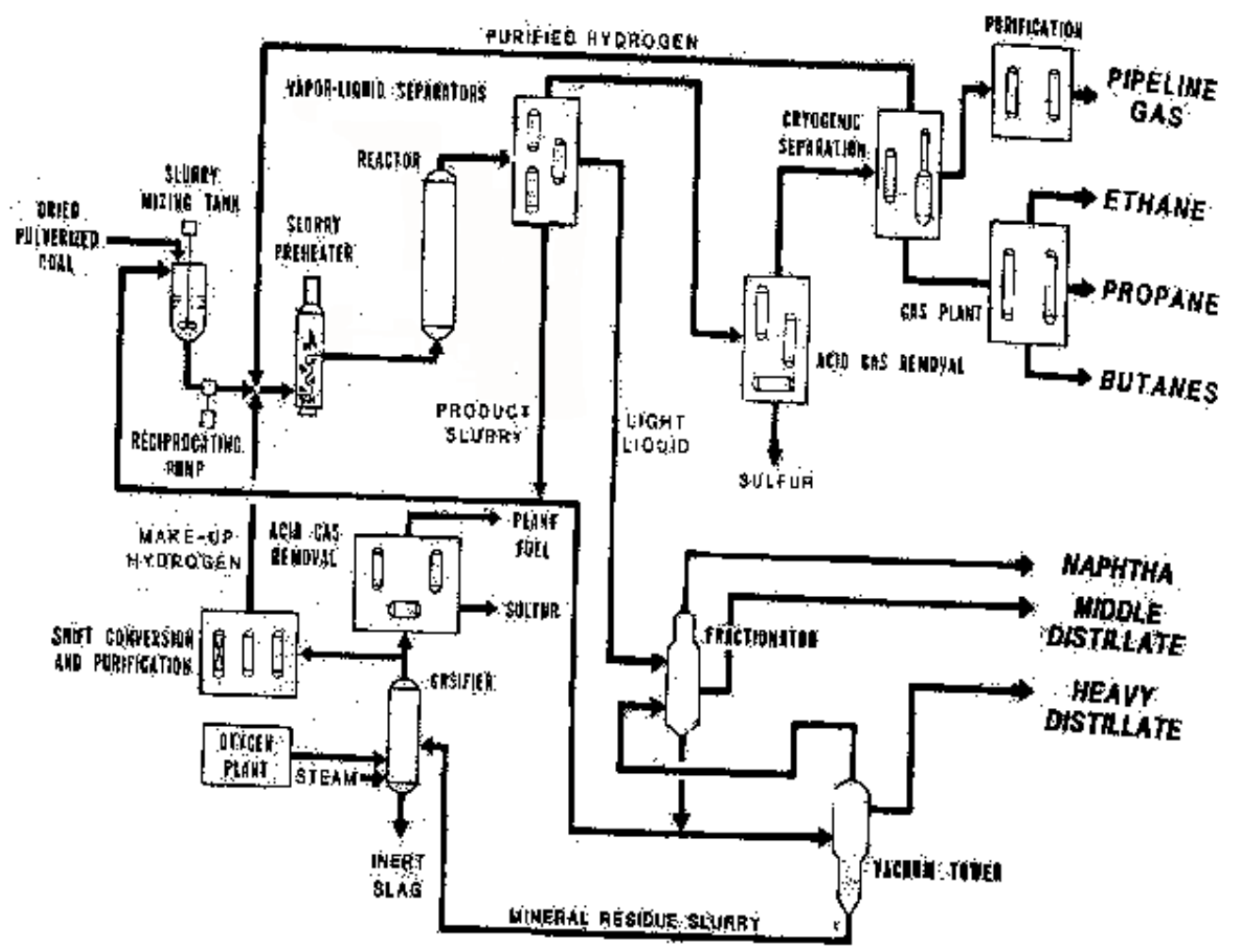

Figure 3-3. SRC-II Demonstration Plant. 


\section{Chapter 4}

\section{H-COAL PROCESS}

\section{C. McCoy - CONSOL Energy Inc.}

\section{BACKGROUND}

In the early 1960's, Hydrocarbon Research Incorporated, HRI, (later Hydrocarbon Technology Incorporated $(\mathrm{HTI})$ ) invented the $\mathrm{H}$-Coal process. It is a single-step, direct catalytic coal liquefaction process and it is essentially an extension of the fully commercialized $\mathrm{H}$-Oil process for hydro-conversion of petroleum residuum. The heart of the process is the $\mathrm{H}$-Coal reactor (Figure 1$)$, which operates at elevated temperature $\left(800^{\circ} \mathrm{F}\right.$ $850^{\circ} \mathrm{F}$ ) and pressure (3000 psi). In the reactor a mixture of pulverized coal, a process derived recycled solvent, and hydrogen are contacted together and move through an ebullated catalyst bed. This converts the coal to lighter hydrocarbon liquids and gaseous products, which flow overhead from the reactor to separation equipment and processing operations. Expansion of the ebullated catalyst bed is achieved through the use of specially designed reactor internals, which allow liquid from above the catalyst bed to be pumped back as required through the reactor. Periodically fresh catalyst is charged to the reactor and spent catalyst is withdrawn to maintain catalyst activity.

Process development proceeded from conceptual design and testing in 25-pound-per-day (coal feed rate) "Bench Units", to a three-ton-per-day Process Development Unit (PDU), and finally to a 200 to 600 ton-per-day pilot plant. The Bench and PDU facilities were located at HRI's Trenton, New Jersey, laboratories. The H-Coal pilot plant was built adjacent to the Ashland Oil Company oil refinery at Catlettsburg, KY, to take advantage of the refinery's existing facilities for hydrogen production, sulfur recovery, waste water treatment and laboratory and engineering facilities.

The pilot plant was designed for two modes of operation identified as Syncrude Mode and Fuel Oil Mode. The modes differed primarily in the severity of coal processing, with the highest severity for the Syncrude mode. In the Syncrude mode the nominal coal throughput was 200 ton/day. This produced a wide boiling range product to be used as a crude oil 
substitute to an oil refinery. In the Fuel Oil Mode more coal is processed (600 ton/day) to produce heavy distillates and deashed residuum products which are mainly suitable as boiler and utility fuels.

The overall process scheme of the H-Coal pilot plant is shown in the Figure 4-2 block flow diagram. Coal is received and crushed, then pulverized and dried before being mixed with a process-derived recycled oil. The coal/oil slurry is mixed with hydrogen and heated in a furnace to a temperature $100^{\circ} \mathrm{F}$ to $200^{\circ} \mathrm{F}$ below the $\mathrm{H}$-Coal reactor temperature. The coal/oil/hydrogen mixture then flows through the $\mathrm{H}$-Coal reactor catalyst bed where exothermic hydrogenation reactions occur, raising the feed mixture temperature to that of the reactor and converting the coal and recycled residuum to lighter products. As shown in Figure 4-1, the reactor effluent flows to a high pressure separator drum, which is the first processing stage of the Separation and Cooling Section. The separator drum allows the reactor effluent stream to split into vapor and liquid product streams. The vapor stream is cooled to condense distillates and allow recovery of unreacted hydrogen, which is recycled to the reactor. The separator liquid stream is let down in pressure to evolve dissolved light gases and some clean distillate oils. The light gases are sent to the Sour Gas System for fuel gas recovery and to separate out hydrogen sulfide for sulfur recovery. The distillate oils are collected and sent to the Fractionator and Stabilizer System for separation into naphtha, light distillate, and heavy distillate. The remaining liquid stream, now at low pressure, contains mainly heavy distillates, residuum, unconverted coal, and ash. This stream is sent to the Solids Separation and Distillate Recovery System. Here the stream is split using small liquid cyclones into an "ash-lean" stream, which is recycled to the Slurry Feed Preparation Section, and an "ash-rich" stream. For a commercial plant operating in the Syncrude Mode, this ash rich stream would normally be gasified to produce hydrogen for liquefaction. Since the Ashland Oil refinery provided all the makeup hydrogen, the pilot plant did not have a gasifier. The ash-rich stream was sent to a flaker to produce a high ash solid product, which was tested and found to be a suitable gasifier feedstock.

For a plant operating in the Fuel Oil Mode, the ash-rich stream from the Solids Separation and Distillate Recovery System would be further processed in a deashing step (anti-solvent 
deashing). This produces a concentrated high ash stream suitable as a gasifier feedstock or for on-site boiler fuel and a deashed, low-sulfur flaked residuum stream suitable as industrial or utility boiler fuel.

To prevent precipitation of ammonium salts, which form when process vapors are cooled, small amounts of wash water are injected at various locations in the Reactor Effluent Separation and Cooling System equipment. These waters are collected and routed to the Sour Water System where hydrogen sulfide and ammonia are stripped. The hydrogen sulfide is processed to recover sulfur and the ammonia is recovered and purified for sale. The stripped water is then routed to the Waste Water Treatment System for final clean up of residual organic and inorganic components.

Early process development work was funded initially by the Office of Coal Research (OCR). Later, a consortium of government and private sector sponsors funded the large-scale pilot plant work, which was to test and develop suitable commercial process equipment, confirm the scale-up of PDU results, and provide economic and engineering data for commercial plant designs. Participants in the pilot plant construction and testing were:

U.S. DOE

Commonwealth of Kentucky

Electric Power Research Institute (EPRI) Mobil Oil Co.

Standard Oil of Indiana

Ashland Oil Inc.
Continental Oil Co.

Ruhrkohle Oil \& Gas

Sun Oil Co.

Shell Oil Co.

Atlantic Richfield

Overall project costs were approximately $\$ 309 \mathrm{MM}$, with DOE paying $86 \%$. The pilot plant design, equipment purchase, and laboratory confirmation work were carried out by HRI under contract to OCR (14-32-0002-1544). Ashland Oil Inc. prepared the pilot plant site under contract to OCR's successor, the Energy Research Development Administration (ERDA) under contract E(49-18)-2226. The pilot plant construction and operations work were preformed by Ashland Synthetic Fuels Inc. (ASFI) and Bager Plants, Inc., under ERDA contract E(49-18)-2260 and later under DOE contract DE-AC05-76ET10143 with ASFI. Pilot Plant site preparation was started in September 1975 and completed by the end of 1976. Construction began early in 1977 and lasted 42 months. To facilitate completion of 
minor construction work remaining and plant commissioning, ASFI took over control of the Hydrogenation Unit on October 5, 1979, and the remainder of the plant in January 1980.

Pre-commissioning and startup activities began on October 29, 1979. Testing of the coal preparation equipment, reactor warmup and system pressure testing on nitrogen, a fractionator test run, oil operations, and the hydrotreating of anthracene oil were all completed by the end of May 1980. Between May 29, 1980, and November 18, 1982, eleven pilot plant runs were made with coal slurry feed. Four coal feedstocks were used; three bituminous coals (Kentucky 9, Kentucky 11, and Illinois 6) and one subbituminous coal (Wyodak). However, due to the failure of key systems and components, extended operations on coal were not achieved until Run 6 (1/31/81 to 4/03/81) when the pilot plant was operated in an integrated fashion with uninterrupted coal feed for 45.5 days. Run 6 allowed identification of long term operating problems, which were subsequently addressed, ultimately leading to Run 8 (8/02/81 to $12 / 11 / 81$ ), which lasted for 132 days of uninterrupted operation with 90 days of coal feed.

Considering the severity of operating conditions and a 73:1 throughput scale up from PDU to the $\mathrm{H}$-Coal pilot plant, the original pilot plant test program was ambitious. The operating program was to be 24 months, with 4 months dedicated to start up and oil operations and 20 months of coal operations. The actual operating program extended to 36 months, with 4 months for start up and oil operations, 30 months for coal operations and 2 months for final clean up and inspection. All four coal feedstocks to the $\mathrm{H}$-Coal pilot plant were tested under Syncrude Mode operating conditions. The Fuel Oil Mode operations were eliminated from the program due to funding and schedule constraints, the risk of an extended start up/debugging period for the anti-solvent deashing equipment, and changing environmental legislation (New Source Performance Standards) which made producing a $0.7 \mathrm{wt} \%$ sulfur boiler fuel unattractive. However, by the end to the test program the major objective of demonstrating integrated $\mathrm{H}$-Coal process operation in a large scale facility was achieved.

\section{Accomplishments}

Process Operation and Product Yields Demonstrated 
Except for the step of producing hydrogen from residuum materials, the $\mathrm{H}$-Coal process operation was fully demonstrated in an integrated fashion for the Syncrude Mode. Gasification of flaked residuum was later demonstrated in separate testing at Texaco's Montebello, California, Research Lab. ${ }^{1}$ For the $\mathrm{H}$-Coal pilot plant, material balance data were collected at steady state conditions for Illinois No. 6, and Kentucky No. 9 bituminous coals and for Wyodak subbituminous coal. The yield data closely matched PDU data taken under similar operating conditions (Table 4-1). ${ }^{2}$

Based on an assessment done by Mitre Corporation, the product quality produced during pilot plant runs with Illinois No. 6 coal was quite comparable to that produced during PDU runs. ${ }^{3}$ Table 2 summarizes the product quality results for Illinois No. 6 coal operations. In general, the API densities of the pilot plant naphtha, light distillate, and heavy distillate were all slightly lighter than that obtained for the PDU operations, and heating values were slightly higher. Carbon and hydrogen contents for these fractions were very similar while for the vacuum bottoms stream, the carbon content was higher and the hydrogen content lower than for the PDU vacuum bottoms.

Construction and operation to the $\mathrm{H}$-Coal pilot plant provided the opportunity to determine if process scale up would affect product yields and quality. It also afforded the opportunity to test large-scale equipment under the harsh operating conditions of the $\mathrm{H}$-Coal process. This testing proved to be time well spent, since the pilot plant was largely inoperable during the first year of operation, 1980, due to the failures of many components and systems. As problem areas were identified and addressed, new knowledge was gained and great improvements were made in equipment performance and on-stream operating factor for the pilot plant. By the end of the test program, all necessary data had been obtained to confidently design the reactor section and most other key sections of a commercial $\mathrm{H}-\mathrm{Coal}$ plant. Some areas of moderate commercial risk remained where equipment operation was not completely satisfactory. However, in these areas, cost-effective solutions were identified, although not completely tested. Brief summaries follow of some key equipment performance problems and solutions. For a complete accounting of the pilot plant process and equipment performance, problems, solutions and recommendations refer to the ASFI 
Final Report. ${ }^{4}$ Lessons and knowledge gained in these areas have application not only for commercial H-Coal plants, but generally for most other direct liquefaction processes.

\section{Letdown Valve Performance Improvement}

As currently configured, the $\mathrm{H}-\mathrm{Coal}$ reactor effluent slurry is let down in pressure in two stages from 3000 psi to 1200 psi and then from 1200 psi to about 50 psi. These hightemperature $\left(850^{\circ} \mathrm{F}-710^{\circ} \mathrm{F}\right)$, high-pressure streams contain coal ash solids and are very erosive. Process operability requires rugged letdown valves for this severe service. Each letdown stage consists of two parallel valve trains with upstream double block and bleed valves and, depending upon the service, either double block and bleed valves or a single block valve downstream of the letdown valve to allow for on-line replacement of letdown valves. The originally installed Willis multi-orifice M4HT letdown valves lasted less than ten hours in coal slurry service. ${ }^{5}$ Improvements in design increased the valve life to about 100 hours, but the basic design concept used in this valve (rotating disk throttling) made it unsuitable for the service. To improve valve performance with a goal of achieving at least a 30-day life, the H-Coal Pilot Plant undertook a valve testing and development program. In the program the following five additional valves were tested: Cameron (two versions), Hammel-Dahl, Kieley \& Mueller, Masoneilan Prototype, and Masoneilan Sasol. These valves were all angle-type plug and seat valves which used tungsten carbide trims with downstream restricting chokes to lessen the pressure drop across the valve trims (400 psi of the 1800 psi drop service and 500 psi of the 1150 psi drop service).

By the end of the test program, problems with trim breakage and vibration damage had largely been addressed to the point that erosive wear was the main cause of failure. Four of the five candidate commercial letdown valves demonstrated service life of 500 to 700 hours (21 to 29 days) in the 1400 psi drop service which was close to the test program target of 30 days life. Only the Masoneilan Prototype valve with its extendable-erodible plug showed potential for significantly exceeding the 500-700 hour service life in the $1400 \mathrm{psi}$ drop application. Much longer service times were indicated for valves in the $650 \mathrm{psi}$ drop service. Wear data based on valve pressure drops (total drop minus choke drop) indicated that erosion rate was very roughly a function of the pressure drop squared. This leads one to the conclusion that there should be a four-fold increase in letdown valve life when the 
pressure drop is reduced by one half. Therefore shifting more of the letdown pressure drop to the more wear resistant downstream chokes should significantly increase the letdown valve life. Other important lessons learned from the letdown valve test program included:

- The use of diffusion bonded coatings such as the Turbine Metal Technology, Inc., TMT-745 (Titanium diboride), can significantly increase the valve trim life.

- $\quad$ Commercial systems must incorporate into the design ways to permit controlled heat up of the letdown and block valve trains to prevent thermal shock damage of the tungsten carbide components.

- To minimize the chances of valve plug breakage due to trim misalignment, consideration should be given to not designing the commercial letdown valves for tight shutoff. It was recommended that valve designs provide a small plug seat clearance with adjustable stops to prevent plug/seat contact and to take up for trim wear.

\section{Block Valve Performance Improvements}

Good block valve performance will be critical to achieving high on-stream factors for coal liquefaction plants. Block valves used to isolate the high pressure letdown valves are of particular concern. These valves provide a means of switching between the operating and spare letdown valve trains without discontinuing coal processing. The block valves must provide reliable leak-free tight shutoff to allow isolation and replacement of letdown valves as the valve trim wears out (perhaps every 1000 to 2000 hours). The block valves operate under the severest conditions, including high operating temperature and pressure, high differential pressure, the presence of abrasive slurries with settling solids, and coking conditions. The originally installed Gulf \& Western EPG block valves used in the letdown area performed poorly, lasting less than two cycles (open-close-open). Modifications were made to the valves to eliminate many of the initial problems of stem leakage, scratched ball and seating surfaces, seat spring breakage, and cracked seat rings, but the problem of coke formation between the seat and valve body was not solved. The coking prevented 
retraction of the seats, which was required to allow the ball to be removed through the bonnet opening. This made it necessary to destroy the ball and seats during disassembly.

A block valve test program was developed to address the problems. Three other full-port, metal-seated ball valves were tested at the $\mathrm{H}$-Coal Pilot Plant with better success. The valves were: Mogas, Kamyr, and Cameron. By the end of the test program, valve cycles to failure ceased to be a major concern since several valves were eventually cycled for up to 30 times without loss of tight shutoff. The three alternate valves were considered to be viable candidates for commercial use. The test program allowed ASFI to develop commercial valve specification recommendations specifically for: stem packing, body and bonnet gaskets, body material and design, seat packing and seals, seat material and design, and ball materials and design. ${ }^{4}$

\section{Slurry Charge Pump Performance}

Efforts were made to achieve acceptable on-stream times for the reactor high-pressure slurry charge pumps. These pumps use inlet/outlet check valves around a reciprocating plunger arrangement to raise the feed slurry pressure from nominally 50-90 psi to $3200 \mathrm{psi}$. Problems associated with these pumps are mainly due to wearing of wetted parts (i.e., plunger, plunger packing, and inlet/outlet valves) caused by the presence of abrasive slurry particles in the pumped fluids. For the $\mathrm{H}$-Coal pilot plant the demonstration target for average on-stream time between pump failures (all causes) was 30 days. Actual practice fell far short of this with an average time to failure of about 3 days and an average packing life of about 12 days demonstrated during the last coal run. ${ }^{6}$ Progress was made in identifying suitable plunger materials and coatings which provide excellent plunger life and identifying a pump valve design which never failed during the pilot plant operations. Equipment modifications made at other liquefaction plants, but not tested at $\mathrm{H}$-Coal, on pumps in essentially identical service provided superior pump life performance. To improve plunger/packing life, recommendations include: the use of clean purge fluid with a throat bushing substantially longer than the pump stroke, and the use of surge legs which provide a substantial volume vertical between the plunger and check valves. ${ }^{7}$ The surge leg technique was used by Texaco at the Montebello facility to pump coal liquefaction residues 
to a test gasifier and at the German Bottrop liquefaction pilot plant operated by Ruhrkohle VAG and VEBA OEL AG. Reportedly, for the Bottrop plant, the slurry charge pumps presented no operating problems, including a run that lasted 2000 hours. $^{6}$

\section{$\underline{\text { Reactor Effluent High Pressure Vapor/Liquid Separator Operation }}$}

A generic feature of coal liquefaction processes is the reactor effluent vapor/liquid separator which is located immediately downstream of the reactor. This vessel provides a volume for disengagement of gas from the reactor liquids. Since this separation takes place at high pressure, purification of hydrogen for recycle can be done efficiently and at a low recompression cost. The separators are expected to operate without difficulty for long periods.

At the H-Coal Pilot Plant large masses of solids formed in the lower half of the separator during Runs 6 (46 days) and 8 (90 days), ultimately forcing the pilot plant to be shut down. The deposition was due to solids settling, followed by coking. The problem was solved by installing a gas sparge ring near the bottom of the separator and by filling in the bottom head with refractory to form a cone-shaped discharge. The sparge ring supplied hydrogen gas to agitate and cool the separated liquid, while the bottom conical section eliminated quiescent zones for solids to settle and allowed reduction of the liquid residence time from 5-7 minutes to 1.5 minutes. Operating the high pressure separator with sufficient hydrogen to cool the liquid to $750^{\circ} \mathrm{F}$ eliminated depositions during Runs 9 (25 days) and 10 (30 days) on Wyodak coal and during Run 11 (78 days) on Illinois 6 and Kentucky 9 coals.

Operating temperatures above $750^{\circ} \mathrm{F}$ may be possible without coke formation, but this was not confirmed in the pilot plant since the conical bottom discharge modification and the reduction in operating temperature to $750^{\circ} \mathrm{F}$ were made simultaneously. What is known is that during Run 8 , severe coking occurred in the separator which was operated at $800{ }^{\circ} \mathrm{F}$ with hydrogen sparging; albeit over twice the coal precessing time as for Run 6 . Following Run 8, the conical bottom modification was made to the separator and additional hydrogen was supplied to further reduce operating temperature to $750^{\circ} \mathrm{F}$. All remaining Runs were at the $750{ }^{\circ} \mathrm{F}$ separator temperature without coke formation. 


\section{Distillation Tower Corrosion}

The atmospheric pressure fractionators in the SRC-I, SRC-II, EDS, and $\mathrm{H}$-Coal liquefaction plants all suffered severe corrosion associated with the chloride level in the coal. The proposed mechanism for the $\mathrm{H}$-Coal fractionator corrosion was the presence of thermally unstable amine hydrochlorides in the fractionator feed stream which are decomposed in the fractionator feed heater. This generates hydrogen chloride and aromatic amines. In the cooler upper trays of the fractionator the compounds react to recombine into amine hydrochlorides which then flow back down the tower in the liquid phase. Ultimately the downward flowing organic chlorides reach high enough temperatures in the tower to again decompose. This traps (in effect, refluxes) the chlorides within the tower concentrating them to high levels. Eventually, the chlorides react with iron in the tower trays or in the metal shell forming iron chloride, $\mathrm{FeCl}_{2}$, which leaves with the side stream light oil product or in the fractionator bottoms product. ${ }^{8}$

Various methods of removing chlorides from the fractionator feed, such as operating upstream equipment at higher temperatures to volatilize chlorides or the use of reactants such as sodium bicarbonate to tie up the chlorides, have been proposed. None were definitively tested during the $\mathrm{H}$-Coal demonstration program. However, a considerable body of data was collected at $\mathrm{H}$-Coal using corrosion coupon racks installed in the fractionator, and some changes were made to the fractionator cladding and tray materials during the demonstration program. A number of alloys or metals, such as Inconel 625, Hastelloy C-4, titanium, etc., were highly resistant to chloride attack at conditions experienced. For commercial installations, alternate metallurgy alone, or a combination of process changes to control chloride levels along with metallurgy changes, will certainly correct the problem.

\section{Vacuum Tower Operation}

The H-Coal Pilot Plant, like many other direct liquefaction processes, uses vacuum distillation to recover distillate product (material boiling below $975{ }^{\circ} \mathrm{F}$ ) from the residual material (a mixture of $+975^{\circ} \mathrm{F}$ boiling material, unconverted coal, and coal mineral matter). Vacuum tower bottoms pumping was a problem throughout the pilot plant program. Problems were 
due mainly to high slurry viscosity and to inadequate net positive suction head (NPSH) for the centrifugal pumps. Loss of bottoms pumping capacity to the flaker often occurred due to increases in the bottoms viscosity, which could result from a small change in the bottoms slurry distillate content or a change in slurry temperature. In general, centrifugal pump performance is sensitive to viscosity; increasing viscosity decreases the pump discharge head for a given flow rate, while line pressure drop increases due to higher frictional forces. This often led to loss of vacuum tower level control as required piping pressure drop increases above pump head performance. The low NPSH caused by locating the bottom of the Pilot Plant vacuum tower only 11' 4" above grade, also lead to loss of pump capacity due to vapor locking. Additionally, the short liquid leg caused pump suctions to operate under vacuum conditions which resulted in air leakage through pump seals and inlet suction piping.

Improvements in vacuum system reliability was obtained at $\mathrm{H}$-Coal by removing trays from the stripping section of the vacuum tower so that higher liquid levels could be accommodated and by using reciprocating plunger pumps to transfer vacuum bottoms material to the flaker. For commercial operations, it was recommended that the vacuum tower be raised 30 to 40 $\mathrm{ft}$ above the bottoms pump suction flange and that reciprocating plunger positive displacement pumps be used to transfer the bottoms material to other processing units. Elevating the vacuum tower the recommended amount increases the NPSH at the pump suction and increases the suction pressure above atmospheric, which eliminates air leaks. Positive displacement pumps are well suited for transfer applications, since they are less susceptible than centrifugal pumps to increased head requirements due to viscosity changes. The use of centrifugal pumps to in a pump-around system to feed slurry to the reciprocating plunger pumps was recommended. Pump-around service centrifugal pumps worked well in the reactor coal slurry feed system where absolute viscosity of the slurry was similar to that of the vacuum bottoms.

\section{References for Chapter 4}

1. Wu, C. M.; Robin, A.M. "Gasification of residual materials from coal liquefaction: Type II preliminary pilot-plant evaluation of molten $\mathrm{H}$-Coal liquefaction residue", Contract No. DOE AC01-76ET10137, Report No. DOE/ET/10137-T6; Fe-2247.32, 1982. 
2. $\quad$ "H-Coal Pilot Plant", Final Report, Volume II. 3.0 Pilot Plant Operations, Report prepared by Ashland Synthetics Fuels, Inc., Ashland KY, DOE Contract No. DEAC05-76ET10143, April 1984.

3. Talib, A.: Gray D.; Neuworth, M. "Assessment of H-Coal process developments: impact on the performance and economics of a proposed commercial plant", Miter Corp., McLean, VA, Contract No. DOE AC01-80ET13800, Report No. DOE/ET/13800-5, 1984.

4. $\quad$ "H-Coal Pilot Plant", Final Report, Volumens I-X. Prepared by Ashland Synthetic Fuels, Inc., Ashland, KY, DOE Contract No. DE-AC05-76ET10143, April 1984.

5. $\quad$ "H-Coal Pilot Plant", Final Report, Volume V. 4.0 Equipment Performance, Report prepared by Ashland Synthetic Fuels, Inc., Ashland, KY, DOE Contract No. DEAC05-76ET10143, April 1984.

6. $\quad$ "H-Coal Pilot Plant", Final Report, Volume III.4.0 Equipment Performance, Report prepared by Ashland Synthetic Fuels, Inc., Ashland, KY, DOE Contract No. DEAC05-76ET10143.

7. Irvine, A. R.; Cochran, H. D.; Culberson, O. L.; Fisher, J. F.; Gambill, W. R.; Oswald, G. E.; Salmon, R., "Direct Liquefaction Technology Assessment", Task 1. Technical Readiness of the Developing Plant Functions, Oak Ridge National Laboratory, Report No. ORNL/TM-9181, DOE Contract No. DOE/AC05-84OR21400, September 1985.

8. "H-Coal Pilot Plant", Final Report, Volume VII. 5.0 Material Evaluation, Report prepared by Ashland Synthetic Fuels, Inc., Ashland, KY, DOE Contract No. DEAC05-76ET10143, April 1984. 
Table 4-1

Normalized Material Balance Data Comparison

For Pilot Plant and PDU -- wt \% Moisture Free Coal

\begin{tabular}{|c|c|c|c|c|c|c|c|}
\hline & \multicolumn{3}{|c|}{ Illinois No. 6} & \multirow{2}{*}{$\begin{array}{c}\text { Ky. No. } 9 \\
\text { Run No. } 11\end{array}$} & \multirow{2}{*}{$\frac{\text { Ky. No. } 11}{\text { PDU-9 }}$} & \multicolumn{2}{|c|}{ Wyodak } \\
\hline & Run No. 8 & Run No. 11 & PDU-5 & & & Run No. 10 & PDU-10 \\
\hline $\mathrm{H}_{2}$ & -5.47 & -4.74 & -4.91 & -4.51 & -4.19 & -6.28 & -5.57 \\
\hline Hetrogases & 9.99 & 10.86 & 10.87 & 12.55 & 12.86 & 18.20 & 18.58 \\
\hline$C_{1}, C_{2}, \& C_{3}$ & 11.77 & 9.89 & 10.68 & 10.36 & 9.80 & 9.29 & 9.98 \\
\hline $\mathrm{C}_{4}-400^{\circ} \mathrm{F}$ & 22.41 & 18.55 & 18.74 & 14.74 & 15.05 & 25.95 & 22.12 \\
\hline $400^{\circ} \mathrm{F}-650^{\circ} \mathrm{F}$ & 16.46 & 19.30 & 20.37 & 17.80 & 16.10 & 14.60 & 13.20 \\
\hline $650^{\circ} \mathrm{F}-975^{\circ} \mathrm{F}$ & 8.81 & 10.39 & 7.96 & 10.23 & 10.88 & 9.33 & 10.86 \\
\hline Residuum & 21.26 & 21.68 & 19.00 & 27.38 & 27.59 & 10.65 & 11.27 \\
\hline $\begin{array}{l}\text { Unconverted } \\
\text { Coal }\end{array}$ & 3.46 & 3.51 & 5.78 & 2.18 & 3.64 & 9.12 & 10.72 \\
\hline Ash & 11.31 & 10.58 & 11.51 & 9.27 & 8.27 & 9.13 & 8.84 \\
\hline
\end{tabular}




\section{Table 4-2}

\section{Product Properties Comparison}

\author{
Naphha (180-380 $\left.{ }^{\circ} \mathrm{F}\right)$ \\ Gravity, ${ }^{\circ} \mathrm{API}$ \\ Elemental Analysis, wt \% \\ Carbon \\ Hydrogen \\ Nitrogen \\ Sulfur \\ Oxygen \\ Refractive Index $\left(20^{\circ} \mathrm{C}\right)$ \\ Heating Value, Btu/lb
}

PDU

$\underline{\text { Run 5, Period } 29}$

36.5

85.14

12.00

0.31

$0.83(1)$

1.47

18,278

15.4

87.54

9.57

0.52

1.03

1.529

17,706

Pilot Plant

$\underline{\text { Run 8, 4-day Material Balance }}$

39.6

86.78

12.66

0.19

0.26

1.61

1.459

19,104

18.0

87.47

9.82

0.56

0.09

$2.84(2)$

1.530

17,947

$-5.9$

0.3

89.7

7.13

89.06

7.09

1.25

0.26

0.97 (1)

75

16,742

1.94 (4)

70

17,059

59.18

63.15

4.08

3.93

0.99

2.32

1.37

1.38

2.38

1.06

27.94

(1) Unteraucher.

(2) By neutron activation.

(3) For PDU-5, cut was 650-975 F.

(4) By difference. 


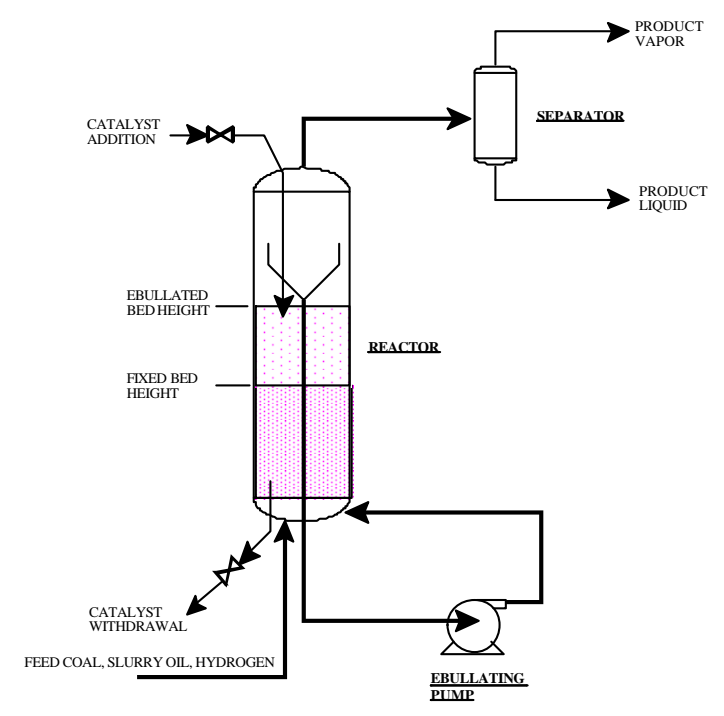

Figure 4-1. H-Coal Reactor

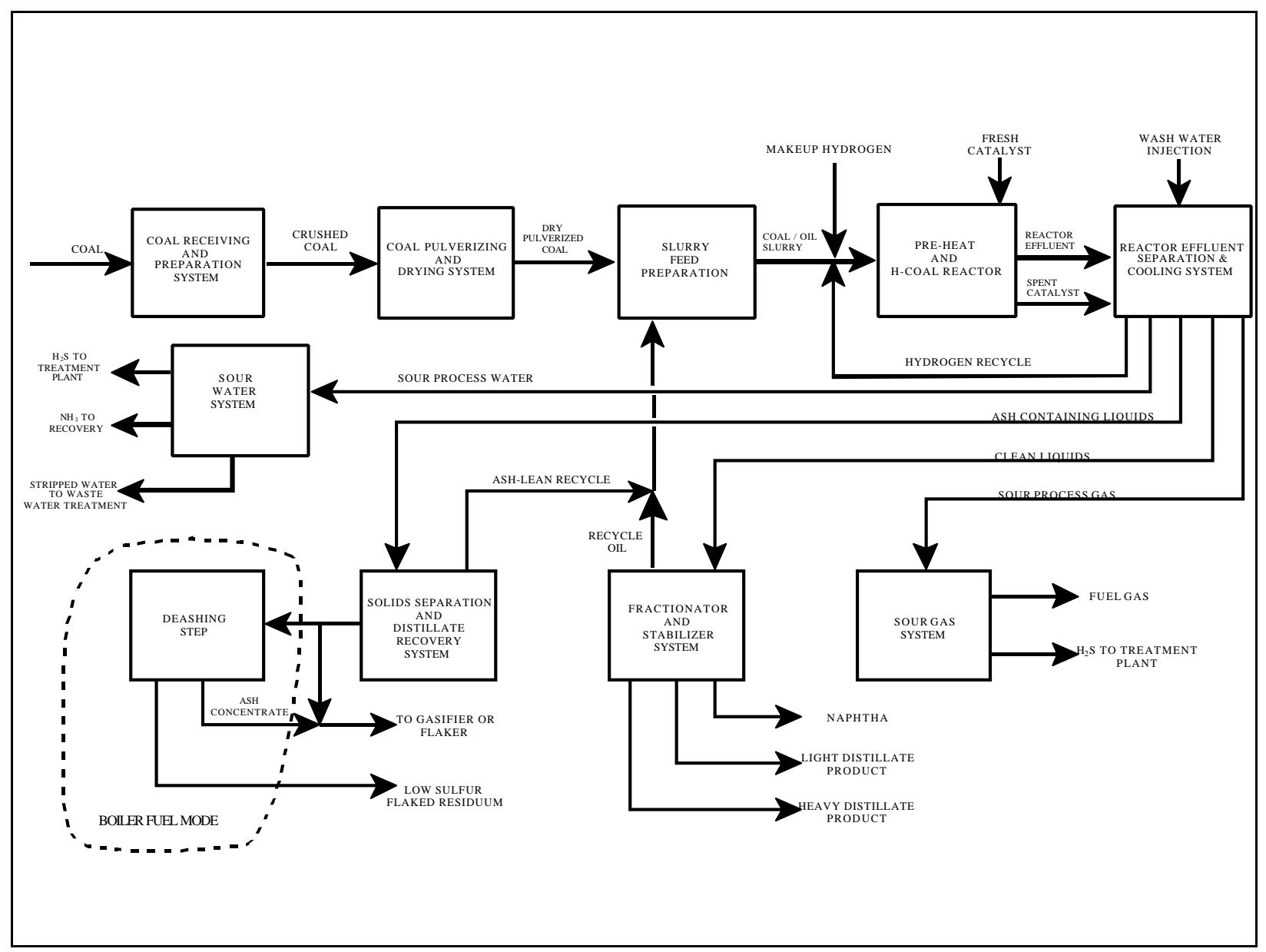

Figure 4-2. Block Flow Drawing -- H-Coal Process 


\section{Chapter 5}

\section{LUMMUS INTEGRATED TWO-STAGE LIQUEFACTION PROGRAM ${ }^{1}$}

\section{R. A. Winschel - CONSOL Energy Inc.}

The Lummus Co. began developing a process known as the Lummus Clean Fuels From Coal (LCFFC) Process in 1972. The LCFFC process used an expanded-bed catalytic hydrocracker and Lummus antisolvent deashing to generate either an all-distillate or boilerfuel product. ${ }^{2,3}$ Other work beginning in 1976 by Cities Service Co. and the Lummus Co. under DOE Contract EX-76-C-01-2038 (later renamed DE-AC22-76ET10135) had indicated that it was possible to process solvent refined coal (SRC) and short-contact-time (SCT) coal extract with Cities Service's expanded-bed hydroprocessing technology known as LCFining. ${ }^{4}$ These results suggested an integration of thermal liquefaction and catalytic hydroprocessing, in which the thermal liquefaction step would be operated to produce high yields of coal extract with little concern for desulfurization, distillate yield, or recycle solvent self-sufficiency, and the bulk of the hydrogenation, desulfurization, and distillate make would take place in the catalytic unit, which would be operated at a lower temperature, thus minimizing gas make and hydrogen consumption. To protect the catalyst in the hydroprocessing unit, the coal extract first would be deashed, via Lummus antisolvent deashing (ASDA). The highest boiling fraction of the catalytic reactor product would become the recycled pasting solvent, allowing the process to produce an all-distillate liquid product. The original idea was to produce a distillate fuel oil $\left(850 \mathrm{EF}^{-}\right)$that could be used without further refining. This conceptual two-stage liquefaction process had many similarities to other twostage liquefaction concepts, such as the earlier CONSOL Synthetic Fuels process and the Chevron process, which was pilot tested at the $5 \mathrm{t} / \mathrm{d} \mathrm{scale}^{5}$. This integrated SCT/ASDA/LCFining process was developed under DOE Contracts DE-AC22-79ET14804, from 1979 to $1983,{ }^{6-9}$ with Lummus as the prime contractor and Cities Service as a subcontractor and under DE-AC22-82PC50021, from 1982 to 1985, with Cities Service as the prime contractor and Lummus as the subcontractor. Associated research on the role of hydrogen donor solvents was conducted by Cities Service from 1983 to 1985 under DOE Contract No. DE- 
AC22-83PC60047. This chapter mainly concerns the work conducted on the integrated twostage liquefaction process development unit (PDU) in New Brunswick, NJ.

\section{Description of PDU}

A process development unit (PDU) was constructed at the New Brunswick, NJ, facilities of Lummus to develop the integrated process; the 20-30 lb/h unit was started-up in April 1980 (Figure 5-1). The PDU was really three separate units (SCT, ASDA, and LC-Finer), which were often operated in a blocked-out semi-batch mode, rather than in a fully integrated continuous manner (Figure 5-2). The following is a description of a typical operation prior to 1982 . Coal $(20-30 \mathrm{lb} / \mathrm{h})$ and recycle oil in a $2 / 1$ ratio were mixed with hydrogen and passed through the SCT reactor, a 3.6" x $177 \mathrm{ft}$ coil typically operated at 2000 to $2400 \mathrm{psig}$ and temperatures of $600 \mathrm{EF}$ (inlet) and 830 to $860 \mathrm{EF}$ (outlet). Residence times at temperatures greater than $800 \mathrm{EF}$ were about two minutes. The products were sent through a separation system to remove gases and light oil, and to generate an atmospheric flash bottoms stream for processing in the ASDA and LC-Fining units. The atmospheric flash bottoms were accumulated for deashing in the ASDA unit.

The ASDA feed was heated, mixed with antisolvent, then allowed to settle. The underflow was sent to a vacuum flash unit to remove antisolvent and coal-derived distillate and the resid was drummed out. (In a commercial unit, this stream would be gasified.) The overflow streams were stripped of antisolvent in an atmospheric flash unit, stripped of middle distillate in vacuum flash unit, and the bottoms were accumulated as feed for the LC-Finer; the vacuum overhead stream was recycled as SCT solvent. The flash overheads containing antisolvent were combined and distilled to recover antisolvent, and the coal-derived bottoms were recycled as SCT solvent (or sometimes blended with the feed to the LC-Finer).

In the Lummus PDU, the LC-Finer consisted of three expanded-bed catalytic reactors in series. Each reactor was equipped for liquid recycle. Deashed SCT product was mixed with hydrogen, preheated, then passed into the LC-Finer unit, which was typically operated at 700 to $760 \mathrm{EF}$. The product was separated into gases, water, light oil and heavy oil, which at various times having an initial boiling point of nominally 500,650 , and $750 \mathrm{EF}$. The 
heavy oil was combined with the material from the ASDA unit and recycled at pasting solvent to the first stage.

The PDU was operated as described above for Runs 3LCF1 through 3LCF7 with Indiana V coal, and 3LCF8 with Illinois 6 coal. Modifications to the operating mode were made for later runs, as described below.

\section{PDU Test Program}

The three sub-units of the PDU (first-stage reaction, deasher, second-stage reaction) were operated in blocked-out manner, rather than in a truly integrated manner. In fact, it was common to have only one or two of the sub-units operating at the same time, and rather uncommon for all three to be operating simultaneously. For the most part, a single catalyst charge defined a "run" in the LC-Finer, whereas a continuous (or nearly so) operating period defined a "run" in the first-stage reaction system. All LC-Finer PDU runs are named "3LCFX", where "X" represents the serial number of the run. The digit "3" defines the run as being made on the PDU LC-Finer, as opposed to other test units. Table 5-1 lists the operating conditions of various PDU tests, grouped by LC-Finer run number. The conditions of the first-stage reaction tests that were most closely associated with a particular LC-Finer run are shown on the same line of the table.

The blocked-out fashion in which the three units were operated mandated large surge capacity for recycle oils and intermediate products (see Figure 5-2) and large quantities of start-up oil. Koppers creosote oil, prehydrogenated in the LC-Finer, was typically used as a start-up and make-up oil. It appears likely that the Lummus PDU operations never generated an "equilibrium" solvent, i.e., a recycle stream that was truly process generated. An additional difficulty with process operations was the continuous aging of the catalyst; operationally, this was handled by slowly increasing the LC-Finer temperature as the run progressed.

Coals tested in the Lummus PDU included Indiana V seam (Old Ben No. 1 Mine) and Illinois 6 seam (Burning Star No. 2 Mine) bituminous coals, and Wyoming Powder River Basin subbituminous coal. Early tests used the same cobalt/molybdenum on alumina catalyst used 
in the $\mathrm{H}$-Coal program, American Cyanamid 1442A. However, most later tests used an extruded nickel/molybdenum on alumina catalyst, Shell 324M, in the Lummus PDU LC-Finer. Catalyst activity was found to decrease rapidly from the fresh state and leveled out after about 300-400 pounds of $850 \mathrm{EF}^{+}$resid per pound of catalyst had been processed. In the PDU, catalyst ages reached as great as 1800 pounds of $850 \mathrm{EF}^{+}$resid per pound of catalyst.

All LC-Finer tests prior to Run 3LCF6 where short tests, primarily to shake-down the unit and verify operability. As the Lummus PDU was originally operated (through Run 3LCF8), the coal extract fed to the second-stage LC-Finer reactor was deashed in order to protect the catalyst. Because of deasher operating inefficiencies, the LC-Finer was fed extract containing fairly high levels of coal ash and solids on occasion, with no apparent detriment. This led to the concept of moving the deasher unit downstream of the LC-Finer. This improved process efficiency considerably by reducing the complexity of the separation steps and by introducing a stream (LC-Finer product) to the ASDA unit that was much easier to deash. In this modified flow-scheme, the SCT product was flashed to $500 \mathrm{EF}$ and sent directly to LC-Fining. The $500 \mathrm{EF}^{+}$LC-Finer product was deashed and the deashed $650 \mathrm{EF}^{+}$ product was recycled the first stage. In this mode, all of the pasting solvent was hydrotreated by the LC-Finer. This modification was first tested in Run 3LCF9 with Illinois 6 coal, and resulted in a $4 \%$ absolute increase in overall distillate yield from the process. Catalyst analyses showed that metals and carbon deposition on the catalyst did not increase in this operating mode, relative to the original mode.

At the end of Run 3LCF9 (Illinois 6 coal), some changes were made in preparation for operations with subbituminous coal: the first-stage SCT coil reactor was supplemented by a downstream longer-residence-time "soaker" reactor and the first-stage pressure was reduced to $1000 \mathrm{psig}$. The added reactor volume increased residence time above $800 \mathrm{EF}$ by about 7 to $10 \mathrm{~min}$ from about $2 \mathrm{~min}$. The initial first-stage test with subbituminous coal, Run 2SCT1, gave low coal conversion and calcitic deposits that plugged the soaker reactor. In order to extend the residence time of the unconverted solids and reduce deposition, Lummus began to recycle some of the ash concentrate stream of the deasher; the ash concentrate was $20 \%$ of the recycle stream in Run 2 SCT2 and $30 \%$ in Run 2 SCT3. The 
recycle of solids to the first stage was helpful, but it still was not possible to consistently obtain $90 \%$ coal conversion with the system. Therefore, the "soaker" reactor was replaced by the "heater" reactor. The "heater" reactor had the same volume as the "soaker", but it was plug flow and had much greater gas hold-up. Residence times with the preheater coal and "heater" reactor combination were about 5 to $10 \mathrm{~min}$. The "heater" reactor was used for Run 2SCT5 and all subsequent first-stage testing on the PDU. Relative to operation of the preheater coil as the only first-stage reactor, the preheater/ soaker and preheater/heater combination had no significant effect on conversion, hydrogen consumption, or selectivity, but the first-stage product $\mathrm{H} / \mathrm{C}$ ratio decreased somewhat and it was less reactive in the LC-Finer. Subbituminous coal was tested in that configuration in Run 3LCF10. Also in Run 3LCF10, the recycle of ashy material to the first-stage reactor was tested for the first time. Run 3LCF10 demonstrated that subbituminous coal was an attractive feedstock; although it generated lower distillate yield, its low cost, higher reactivity in the second-stage reactor and ease of deashing were favorable.

The end of Run 3LCF10 (Runs 4SCT1 and 4SCT2) was operated with Illinois 6 coal with ash recycle and the first-stage was operated at only 1000 psi and 500 psi, with no effect of yields or hydrogen usage, relative to baseline operation.

Operation of the Lummus ITSL PDU ceased in 1984. By that time, the larger Wilsonville pilot plant was operating in the two-stage liquefaction mode, and DOE's two-stage liquefaction development program continued at that location.

Table 5-2 shows representative process yields from the ITSL PDU with the three feed coals tested. Table 5-3 shows the elemental analysis of certain net product fractions. Being aware of the blocked-out nature in which the PDU tests were conducted and the uncertainty concerning complete line-out of the start-up oils, the reader may choose to use caution when examining the yield and product quality data presented.

\section{Associated Testing}

Various support and development testing was conducted as part of the ITSL process development effort. This included liquefaction testing in microautoclaves, hydroprocessing 
in small continuous-flow catalytic reactors, such as the BLCF and 4LCF units, hydrocracking testing, and coking testing.

Testing on a small-scale fixed-bed hydrocracker showed that much of the LC-Finer reactor volume could be replaced with fixed-bed hydrocracking and produce a clean distillate, the $650 \mathrm{EF}^{-}$fraction of which contained less than $100 \mathrm{ppm}$ of sulfur and less than $500 \mathrm{ppm}$ of nitrogen. This distillate was claimed to be the cleanest product made by direct liquefaction up to that time. In this conceptual mode, the LC-Finer would be operated at high space velocity to hydrogenate the material, the resid would be sent to the deasher, and the vacuum distillate would be sent to the fixed-bed hydrocracker.

Chen and Schindler ${ }^{10}$ reported a lumped kinetic model for hydroprocessing coal-derived vacuum resid. The model was based on work conducted with Illinois 6 coal products and Shell 324 catalyst in the BLCF and 4LCF units.

Some testing was conducted to determine the potential for coking the deasher ash reject stream to generate additional distillate product. Coker distillate yields of about $20 \%$ of the feed were obtained.

\section{Major Accomplishments}

The Lummus ITSL program made several important process learnings that were later incorporated in DOE's two-stage liquefaction development program at the Wilsonville pilot plant:

- The initial rapid deactivation of the catalyst in an expanded-bed hydrotreater is caused primarily by carbon laydown. A slower deactivation is caused by deposition of soluble metals. The catalyst can tolerate coal mineral matter and undissolved coal organic matter. Thus, it is beneficial to place the deasher downstream of the hydrotreater. This operating tactic greatly eases deasher operation and improves product yield by reducing organic rejection and increasing conversion opportunities. 
- Recycling undissolved coal organic matter as a component of the recycle solvent improves yields of distillate products by allowing additional residence time for conversion and reducing organic rejection. This operating tactic also reduces the service requirements of the deasher.

- The vast reserve of U.S. subbituminous coal is an attractive feedstock for direct coal liquefaction. Liquid yields per ton of coal are less than for bituminous coal and the kinetics of primary dissolution are slower; however, the low cost of the coal and its ease of conversion to distillate liquids are favorable features.

\section{References for Chapter 5}

1. Technical Reports Under DOE Contracts DE-AC22-79ET14804, DE-AC2282PC50021, and DE-AC22-83PC60047.

2. Simone, A. A.; Long, R. H.; Peluso, M. "The C-E Lummus Clean Fuel From Coal Process", presented at Coal Technology '79, Houston, TX, November 1979, vol. 3, pp.263-287.

3. Schindler, H. D.; Sze, M. C.; Long, R. H.; Unger, H. "LCFFC Process Boosts Hydrogen Efficiency" Oil \& Gas J. 1980, 78 (24), 88-92.

4. Potts, J. D.; Chillingworth, R. S.; Hastings, K. E.; Schindler, H.; Burke, F. P. "LC-Fining Support Activities For Two-Stage Liquefaction", presented at the $74^{\text {th }}$ National Meeting of the Am. Inst. Chem. Eng., November 1981, New Orleans, LA.

5. $\quad$ Schindler, H. D. "Coal Liquefaction", Hydrocarbon Processing 1982, 61 (6), 88.

6. Peluso, M.; Schiffer, A. N.; Schindler, H. D. "The Integrated Two Stage Liquefaction Process (ITSL)", presented at Coal Technology '81, Houston, TS, November 1981, vo. 4, pp. 353-379.

7. Schiffer, A. N.; Peluso, M.; Chen, J.; Schindler, H. D.; Potts, J. D. "An Update of the Integrated Two-Stage Liquefaction Process (ITSL)" presented at the National Meeting of the Am. Inst. Chem. Eng., February-March 1982, Orlando, FL.

8. Schindler, H. D.; Chen, J. M.; Peluso, M.; Moroni, E. C.; Potts, J. D. "The Integrated Two Stage Liquefaction Process (ITSL)", Chemical Economy \& Engineering Review 1982, 14 (3), 15-20.

9. Schiffer, A. N.; Peluso, M.; Chen, J.; Schindler, H. D. "Integrated Two-Stage Coal Liquefaction" Energy Progress 1982, 2 (4), 220-3.

10. Chen, J. M.; Schindler, H. D. "A Lumped Kinetic Model for Hydroprocessing Coal Extract" Ind. Eng. Chem. Res. 1987, 26, pp. 921-7. 
TABLE 5-1

\section{LUMMUS ITSL PDU RUN OPERATING CONDITIONS}

\begin{tabular}{|c|c|c|c|c|c|c|c|c|c|c|c|c|c|c|c|c|c|}
\hline \multirow[b]{2}{*}{$\begin{array}{l}\text { LC- Finer } \\
\text { Run }\end{array}$} & \multirow[b]{2}{*}{ Date } & \multirow[b]{2}{*}{$\begin{array}{l}\text { Feed } \\
\text { Coal }\end{array}$} & \multicolumn{7}{|c|}{ LC-Finer Operating Conditions } & \multirow[b]{2}{*}{ Notes } & \multicolumn{7}{|c|}{ Conditions of Associated First-Stage Runs } \\
\hline & & & Catalyst & $\begin{array}{l}\text { Max } \\
\text { T, EF }\end{array}$ & $\begin{array}{l}\text { Avg. } \\
\text { T, EF }\end{array}$ & $\begin{array}{c}\mathrm{P}, \\
\text { psig }\end{array}$ & $\begin{array}{c}\text { Rel. } \\
\text { Feed, SV }\end{array}$ & $\begin{array}{c}\text { LHSV, } \\
\text { vol } \\
850 \mathrm{EF}^{+1} \\
\text { vol set. }\end{array}$ & $\begin{array}{c}\text { Cat. Age, } \\
\text { lb } \\
850 \mathrm{EF}^{+/} \\
\text {lb Cat. }\end{array}$ & & SCT Runs & $\begin{array}{c}\text { Coal } \\
\text { Space } \\
\text { Rate } \\
\mathrm{lb} / \mathrm{h} / \mathrm{ft}^{3}\end{array}$ & $\begin{array}{c}\text { Coal } \\
\text { Feed } \\
\text { Rate } \\
\text { MF lb/h }\end{array}$ & $\begin{array}{l}\text { Coal } \\
\text { Conc. } \\
\% \text { MF }\end{array}$ & $\begin{array}{l}\text { Gas } \\
\text { Rate, } \\
\text { SCFH }\end{array}$ & $\begin{array}{c}\text { Outlet } \\
\text { Temp., } \\
\text { EF }\end{array}$ & $\begin{array}{c}\mathrm{P} \\
\text { Outlet, } \\
\text { psig }\end{array}$ \\
\hline 3LCF1 & $5 / 80$ & Ind V & AC1442A & 750 & & 2500 & $1.0-1.7$ & 0.235 & & & SCT3 & $116-130$ & $15-16$ & 36 & & 860 & 2500 \\
\hline 3LCF2 & $6 / 80$ & Ind V & & $750-780$ & & 2700 & 1.7 & $0.3-0.42$ & & & SCT4 & 247 & 30 & 36 & & 860 & 2400 \\
\hline 3LCF3 & $6-7 / 80$ & Ind V & & 770-805 & & 2700 & 3.3 & 0.382 & & & SCT5 & 111 & 14 & 36 & & 860 & 2400 \\
\hline 3LCF7 & $12 / 80-10 / 81$ & Ind V & S324M & $750-780$ & $740-760$ & 2700 & $1-1.67$ & $0.2-0.6$ & $0-1025$ & & SCT14-24 & $100-200$ & 20 & 36 & $150-230$ & 860 & 2450 \\
\hline 3LCF8 & $10 / 81-2 / 82$ & III 6 & S324M & $750-780$ & $719-750$ & 2700 & 1.67 & $0.37-0.56$ & $0-596$ & & 2SCT1-10 & $100-185$ & & 36 & 165 & 828-865 & $2000-2450$ \\
\hline 3LCF9 & $3 / 82-2 / 83$ & III 6 & S324M & $750-780$ & $725-750$ & 2700 & $1-2.3$ & $0.2-0.6$ & $0-1802$ & a & 2SCT12-18 & $145-180$ & & $30-36$ & $95-165$ & 840 & $2000-2040$ \\
\hline 3LCF9 & $1-2 / 83$ & III 6 & S324M & & & & & & & $b$ & 2SCT17 & 85 & & 36 & 106 & $800-820$ & $1040-2060$ \\
\hline 3LCF10 & 4/83-2/84 & Wyo & S324M & $700-730$ & $675-700$ & 2700 & $1.7-2.4$ & $0.3-0.55$ & $0-735$ & c & $3 S C T 1-5$ & & 20 & 36 & $80-165$ & $840-850$ & 2000 \\
\hline 3LCF10 & $2-3 / 84$ & III 6 & S324M & $750-770$ & $720-736$ & 2700 & 2.4 & $0.47-0.71$ & 797-1101 & $d$ & 4SCT1-2 & $60-93$ & $20-30$ & 36 & 116-165 & $820-850$ & $500-1000$ \\
\hline
\end{tabular}

a. Operated with ashy LCF feed beginning in July 1982.

Soaker reactor added to first stage during Run 2SCT17, January and February 1983.

Soaker reactor added to first stage (heater reactor used in Run 3SCT5), ashy feed to LC-Finer, ash recycle to stage 1 during Runs $3 S C T 1$ to $3 S C T 3$.

d. Heater reactor used, ashy LCF feed, deashed recycle. 
TABLE 5-2

\section{LUMMUS ITSL PDU YIELD STRUCTURE WITH INDIANA V COAL IN ORIGINAL OPERATING MODE}

\begin{tabular}{|l|r|r|r|}
\hline \multicolumn{1}{|c|}{ Product } & $\begin{array}{c}\text { Indiana V Coal, } \\
\text { Original } \\
\text { Operating Mode, } \\
\text { Yield, } \\
\text { wt \% MF }\end{array}$ & $\begin{array}{c}\text { Illinois 6 Coal, } \\
\text { Modified } \\
\text { Operating Mode, } \\
\text { Yield, } \\
\text { wt \% MF (a) }\end{array}$ & $\begin{array}{c}\text { PRB } \\
\text { Subbituminous } \\
\text { Coal, Yield, } \\
\text { wt \% MF (c) }\end{array}$ \\
\hline Hydrogen Consumed & -4.17 & -4.80 & -3.41 \\
\hline $\mathrm{H}_{2} 0, \mathrm{H}_{2} \mathrm{~S}, \mathrm{NH}_{3}, \mathrm{CO}_{\mathrm{x}}$ & 13.26 & 13.32 & 20.00 \\
\hline $\mathrm{C}_{1}-\mathrm{C}_{3} \mathrm{Gas}$ & 3.76 & $6.61^{\mathrm{b}}$ & 4.56 \\
\hline Butane & 0.78 & & 0.94 \\
\hline $\mathrm{C}_{5}$-390 EF Naphtha & 6.65 & 10.35 & 7.69 \\
\hline $390-650 \mathrm{EF}$ Distillate & 34.63 & 31.62 & 16.57 \\
\hline $650-850 \mathrm{EF}$ Distillate & 8.01 & 6.44 & 14.77 \\
\hline Solids-Free 850 EF+ Resid & 19.28 & 18.96 & 18.67 \\
\hline Unconverted Coal & 7.15 & 7.27 & 10.03 \\
\hline Ash & 10.65 & 10.23 & 10.20 \\
\hline
\end{tabular}
a. The cut point for the Illinois 6 coal products is reported as $400 \mathrm{EF}$, rather than $390 \mathrm{EF}$.
b. Includes butane
c. The cut point for the PRB coal products is reported as $500 \mathrm{EF}$, rather than $390 \mathrm{EF}$. 
TABLE 5-3

ELEMENTAL COMPOSITION OF PRODUCT FRACTIONS

\begin{tabular}{|l|l|l|l|l|l|l|l|}
\hline \multicolumn{1}{|c|}{ Feed Coal } & \multicolumn{1}{|c|}{ Fraction } & $\begin{array}{c}\mathrm{C}, \\
\text { wt } \%\end{array}$ & $\begin{array}{c}\mathrm{H}, \\
\text { wt } \%\end{array}$ & $\begin{array}{c}\mathrm{O}, \\
\text { wt \% }\end{array}$ & $\begin{array}{c}\mathrm{N}, \\
\text { wt } \%\end{array}$ & $\begin{array}{c}\mathrm{S}, \\
\text { wt \% }\end{array}$ & $\begin{array}{c}\text { Gravity, } \\
{ }^{\circ} \mathrm{API}\end{array}$ \\
\hline Indiana V (a) & $\mathrm{C}_{5}-850 \mathrm{EF}$ & 88.56 & 10.57 & 0.65 & 0.14 & 0.08 & 17.1 \\
\hline Illinois 6 (b) & $\mathrm{C}_{5}-850 \mathrm{EF}$ & 88.64 & 10.55 & 0.56 & 0.19 & 0.06 & 16.5 \\
\hline PRB (c) & $\mathrm{C}_{5}-500 \mathrm{EF}$ & 85.88 & 11.25 & 2.58 & 0.16 & 0.12 & \\
\hline PRB (c) & $500-650 \mathrm{EF}$ & 89.35 & 10.03 & 0.40 & 0.20 & 0.02 & \\
\hline PRB (c) & $650-850 \mathrm{EF}$ & 90.63 & 8.62 & 0.45 & 0.27 & 0.03 & \\
\hline
\end{tabular}

a. Standard operating mode, Run 3LCF7.

b. Standard operating mode, Run 3LCF8.

c. Modified operating mode, Run 3LCF10.

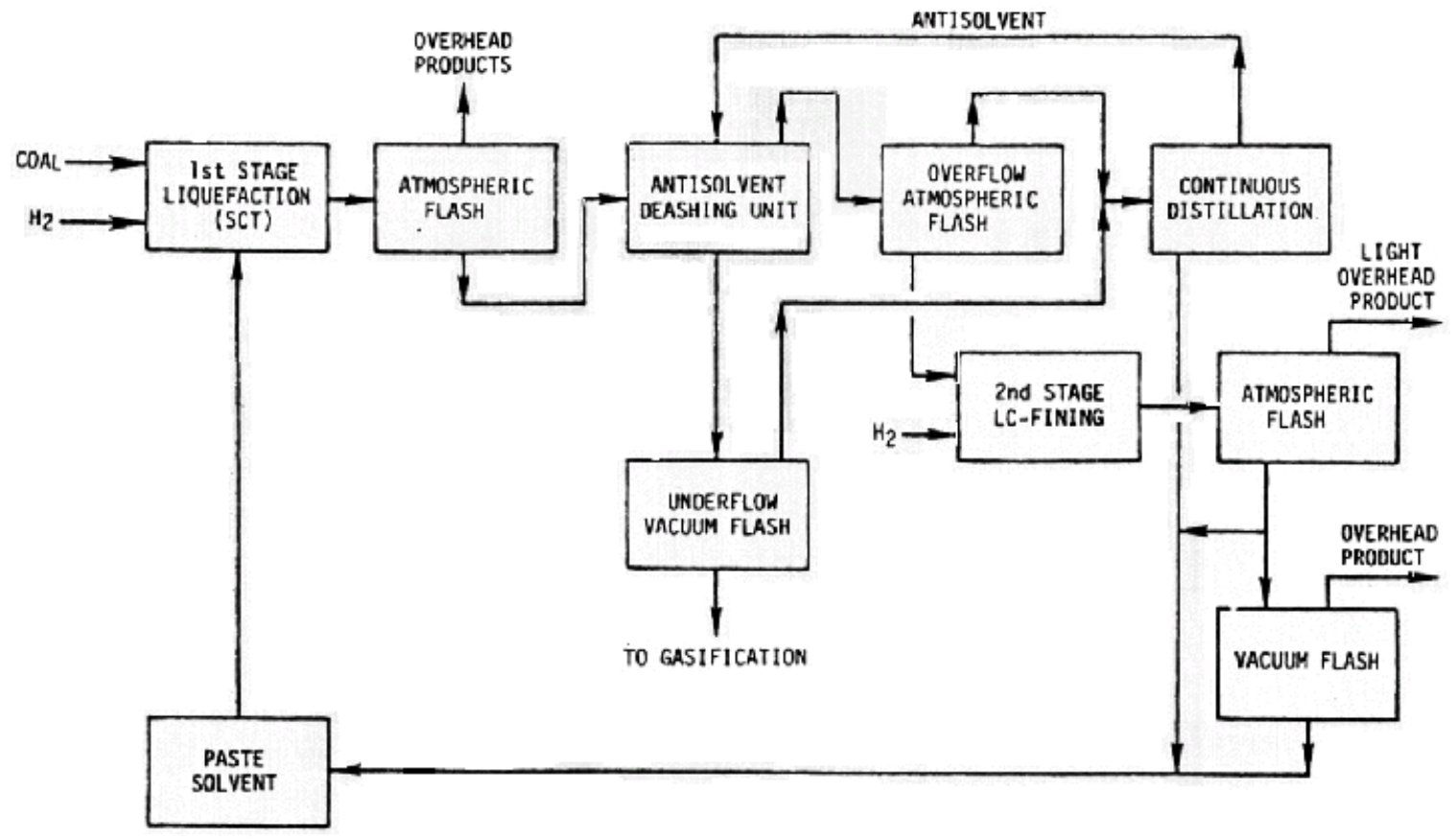

Figure 5-1. Lummus ITSL PDU, Original Operating Mode 


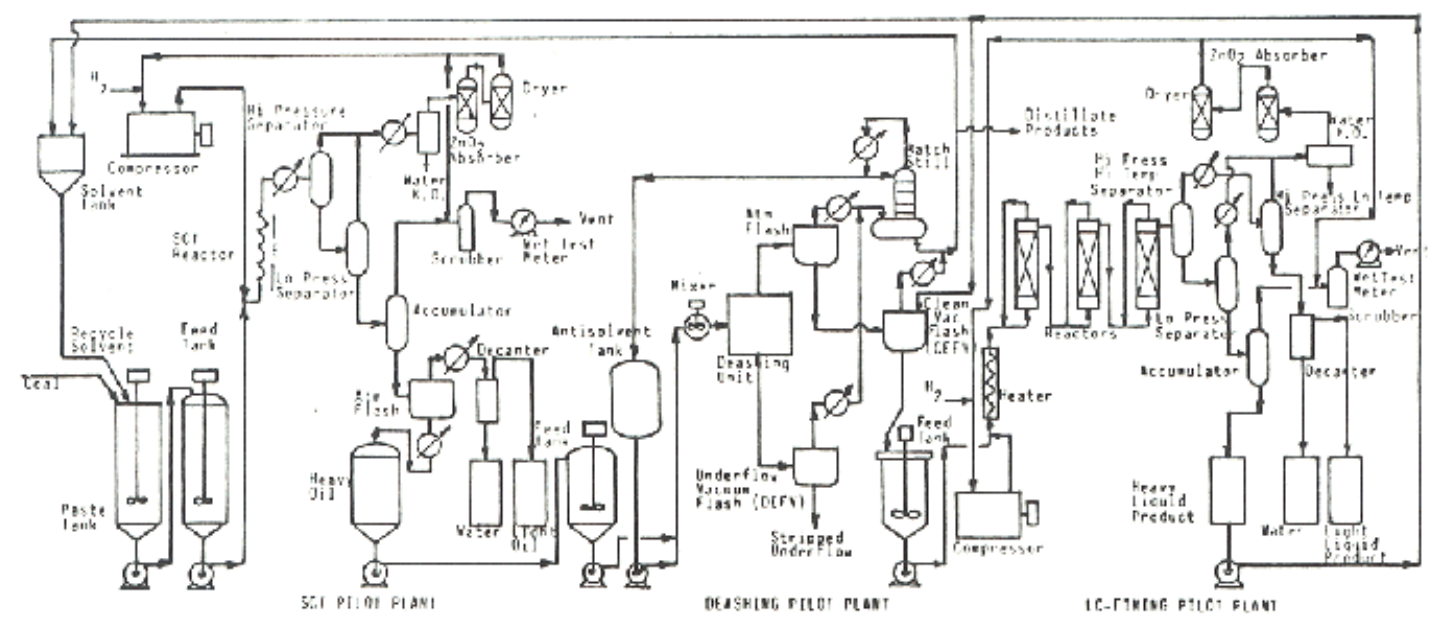

Figure 5-2. Lummus ITSL PDU - Process Flow Diagram. 


\section{Chapter 6}

\section{WILSONVILLE TWO-STAGE LIQUEFACTION PROGRAM ${ }^{1,2}$ \\ R. A. Winschel - CONSOL Energy Inc.}

\section{Background}

In 1972, Southern Company Services and Edison Electric Institute (EEI) began a coal liquefaction R\&D program to develop a process for producing clean boiler fuel from coal. The Electric Power Research Institute replaced the sponsorship of EEI in 1973. The centerpiece of the program, a $6 \mathrm{t} / \mathrm{d}$ pilot plant, was commissioned in 1974 to develop the solvent refined coal (SRC-1) process at Wilsonville, AL. The U.S. Department of Energy became a co-sponsor in 1976, and Amoco Oil became a co-sponsor in 1984 . The pilotplant facility was operated by Catalytic, Inc., and its successor, Stearns-Catalytic, until 1988, and thereafter by Southern Electric International.

The original Wilsonville SRC pilot plant, later to be known as the Advanced Coal Liquefaction Research and Development Facility, contained a single-stage thermal reactor and a filtration unit. In 1978, the filtration unit was replaced by a Kerr-McGee Corp. critical solvent deashing (CSD) unit, later dubbed a ROSE-SR unit, for solids rejection. The major product from SRC-1 operations, whether produced with the filtration or CSD unit, was an ash-free, reduced-sulfur-content, solid (but low-melting) boiler fuel called SRC. The SRC product typically contained 15,500 to $16,000 \mathrm{Btu} / \mathrm{lb}, 1 \%$ sulfur, less than $0.1 \%$ ash, and $2 \%$ nitrogen. The product was tested as a boiler fuel at Georgia Power's Plant Mitchell in 1976 and by Air Products. The Wilsonville plant was operated in the SRC mode until April 1981 (through Run 227), mostly on coals from the Illinois Basin, including coals from various mines operating in the West Kentucky 9 seam (Lafayette, Dotiki, Fies Mines), the West Kentucky 9 and 11 seams (Pyro Mine), the Illinois 6 seam (Burning Star 2 Mine), and the Indiana V seam (Old Ben No. 1 Mine). Beginning in 1979, the Wilsonville operations were conducted to support the design of the planned (but never built) 6000 ton/d SRC demonstration plant in Newman, KY. 
In May 1981, an H-Oil ebullated-bed hydrotreater, supplied by Hydrocarbon Research, Inc., was added, enabling the plant to evaluate two-stage liquefaction (TSL). Early TSL tests 
(Runs 228 through 241) were conducted in the non-integrated (NITSL) mode, in which deashed products of the thermal first stage were hydrotreated, but no hydrotreated products were recycled back to the thermal first stage. In this mode of operation, the major product was a fully liquid fuel oil of higher quality than SRC meant as a substitute for No. 6 petroleum fuel oil; this fuel oil contained components produced in both the thermal first stage and the catalytic second stage. The product, which typically contained 17,800 Btu/lb, $0.1 \%$ sulfur, less than $0.1 \%$ ash, and $0.8 \%$ nitrogen, was tested at Mississippi Power's Plant Sweatt in 1982 and by Amoco Oil. West Kentucky 9 coal from the Fies Mine and Illinois 6 coal from the Burning Star 2 Mine were tested in NITSL operations.

\section{Integrated Two-Stage Liquefaction}

Following NITSL testing, integrated-reactor operating modes were tested beginning in 1982 , in which at least the heaviest deashed hydrotreater products were recycled to the first stage. These operating modes included the integrated TSL, or ITSL (Figure 6-1), and doubly-integrated TSL, or DITSL (Figure 6-2) concepts, both of which feature recycle of heavy deashed hydrotreater products as the slurrying oil. The first ITSL test, Run 242 employed the preheater coil as the first-stage reactor, in many ways mimicking the Lummus TSL concept. All TSL tests after Run 242 utilized an actual first-stage reactor vessel, rather than just a preheater. The "dissolver" vessel was used as a first-stage reactor for Runs 243 through 249. ITSL testing was conducted with Burning Star 2 coal (Runs 242-5, part of Run 248), and Clovis Point Mine Wyoming coal (part of Run 246). DITSL testing was conducted with Clovis Point coal (part of Run 246) and Burning Star 2 coal (part of Run 248). Beginning with the first test of subbituminous coal (Run 246), iron oxide and dimethyl disulfide were added as a slurry catalyst at a rate of 1 to $2 \%$ with the coal feed to overcome the slower dissolution kinetics of that coal. This practice was continued for all later tests with subbituminous coals and lignite, even many those that employed supported catalysts in both reactors; in fact, it was also practiced in Run 248 with bituminous coal.

A common feature of both ITSL and DITSL operations was that the first-stage products were deashed before being fed to the second-stage reactor; one purpose of this was to prevent catalyst deactivation by contact with coal mineral matter. After it was shown by Lummus that expanded-bed catalytic hydrotreaters were not adversely affected by coal 
mineral matter, this constraint was lifted, allowing testing of the reconfigured ITSL, or RITSL (Figure 6-3) mode, in which non-deashed first-stage residual product is hydrotreated in the second-stage reactor. Both Burning Star 2 coal (Run 247) and Wyoming coal (Run 249) were tested in the RITSL mode. RITSL allowed improved yields because of reduced organic matter rejection in the deasher (hydrotreated products were more efficiently deashed) and improved conversion of insolubles (from the additional residence time provided by recycle).

The recycle of the heavy products in all ITSL variations (ITSL, DITSL, and RITSL) resulted, at least in concept, in an all-distillate product slate. The major product of these operating modes was envisioned to be a turbine fuel. Although these configurations resulted in greatly improved product yields and qualities, relative to earlier operations, in each of these configurations, at least a part of the net product was unhydrotreated material generated in the thermal first stage. The product, which typically contained $19,600 \mathrm{Btu} / \mathrm{lb}, 10 \%$ hydrogen, $0.03 \%$ sulfur, less than $0.01 \%$ ash, and $0.13 \%$ nitrogen, was tested at Westinghouse Electric Corp. for performance and emissions.

\section{Close-Coupled Two-Stage Liquefaction}

Prior to Run 250, the thermal first-stage reactor (dissolver) was replaced by a new vessel that was essentially a twin of the second-stage hydrotreater, and various other plant configuration changes were made, to more-closely integrate the two reactors and allow more-flexible plant operations. In all cases, the ROSE-SR deasher was downstream of the reactor pair. This new configuration was dubbed close-coupled ITSL, ${ }^{3,4}$ or CC-ITSL (Figure 6-4). This configuration and its variants, which would last until the end of the Wilsonville program, allowed operations with either, both, or neither reactors containing supported catalysts and acting as ebullated-bed vessels; allowed the use of dispersed catalysts; allowed for operations with (Figures 6-5 and 6-6) or without (Figure 6-7) a high-pressure inter-reactor separator to take off light oils and gases from the first-stage and to increase hydrogen partial pressure in the second stage; allowed for temperature sequenced operation (high/low, low/high) in the two reactors; allowed for catalyst withdrawal and addition in both reactors to maintain constant catalyst activity; allowed for solids recycle as a component of the slurry oil (either as atmospheric, Figures 6-5 and 6-7, or vacuum, Figure 
6-6, bottoms), and allowed for product take-off at various positions in each reactor to reduce reactor volume (increase space velocity) as desired. This configuration permitted the production of an all-distillate hydrotreated product slate that was envisioned to be a feedstock for transportation fuels. Solids recycle was first attempted near the ends of Runs 249 and 250, and it was generally adopted thereafter. Solids recycle conceptually allows a smaller-sized deasher because of the reduced volume of material, albeit with a higher concentration of solids, that must be deashed. The product separation system was upgraded prior to Run 259 to allow a more efficient separation between net product and recycle oil. The interstage separator typically used with low-rank coals was replace by a smaller vessel prior to Run 260.

Most of the tests from Runs 250 through the end of the program (Run 263 in 1992) were designed to evaluate the impacts of configurational changes, operating conditions, catalyst types, and coal types on product yield and quality. Selected operating conditions for all runs from the first ITSL test (Run 242) through the end of the program (Run 263) are shown in Table 6-1. In a general sense, the CC-ITSL program goal was to maximize distillate product yield and quality because it was believed that this would improve the economics of the process as operated commercially, and the program was successful in this regard. Distillate yield was improved by reducing the yields of hydrocarbon gases and organic matter rejected with the mineral matter and distillate quality was improved by limiting the final boiling point of the product. Numerous factors contributed to these improvements, including: solids recycle, which reduced organic matter rejection and aided the effectiveness of dispersed catalysts; high recycle on non-distillable resid; selective use of catalysts and on-line catalyst replacement; selective control of reactor time/temperature; the use of low-ash feedstock coal; tight control of the ROSE-SR deasher and product separation system; and, for subbituminous coals, the use of the "hybrid" catalyst system (dispersed catalyst in first stage, supported catalyst in second stage) and interstage removal of carbon oxides (to prevent methanation). 


\section{CC-ITSL Coals and Catalysts}

From Run 250 onward, the coals tested included bituminous coals (Illinois 6 coal from the Burning Star 2 and Crown II Mines, Ohio 6 coal from the Crooksville Mine (low-ash and highash) and Holmes Mine), Pittsburgh seam coal from the Ireland Mine (low-ash and high-ash)), Powder River Basin subbitminous coal (Clovis Point, Spring Creek, and Black Thunder Mines), and Texas lignite (Martin Lake Mine). Coal analyses are shown in Table 6-2. Supported catalysts tested included Shell 317, Shell 324 (later Criterion 324), Amocat 1A, Amocat $1 \mathrm{C}$, and EXP-AO-60. Amocat $1 \mathrm{~A}$ is a cobalt/molybdenum on alumina catalyst, whereas the others are all based on nickel/molybdenum on alumina. Amocat $1 \mathrm{~B}$, molybdenum on alumina, was also briefly tested in Run 255. The Shell catalysts both have a unimodal pore-size distribution, whereas the others have bimodal pore-size distributions. Shell 317 is trilobed, whereas the others are all cylindrical extrudates. Dispersed catalysts included iron oxide and dimethyl disulfide combination, Molyvan $L$ and Molyvan 822. When used, the iron oxide was typically added at a rate of 1 to $2 \mathrm{lb} /$ ton MF coal and the molybdenum was typically added at a rate of 100 ppm MF coal.

\section{CC-ITSL Process Performance}

The Wilsonville CC-ITSL operations generated high yields of distillate product $(\mathrm{C} 4+$ with an end point of about $850 \mathrm{EF}$, as shown below.

\begin{tabular}{|l|l|c|c|c|c|}
\hline \multicolumn{1}{|c|}{ Coal } & \multicolumn{1}{|c|}{$\begin{array}{c}\text { Run } \\
\text { No. }\end{array}$} & $\begin{array}{c}\text { Measured } \\
\text { Dist. Yield, \%MAF }\end{array}$ & $\begin{array}{c}\text { Measured Organic } \\
\text { Rejection, \%MAF }\end{array}$ & $\begin{array}{c}\text { Potential Dist. } \\
\text { Yield, \%MAF }\end{array}$ & $\begin{array}{c}\text { Assumed Organic } \\
\text { Rejection, \%MAF }\end{array}$ \\
\hline Illinois 6 & $251-I$ & 70.1 & 15.1 & 70 & 15 \\
\hline Illinois 6 & 252 & 69.4 & 17.4 & 70 & 15 \\
\hline Illinois 6 & 253 & 71.6 & 18.4 & 71 & 15 \\
\hline Illinois 6 & 257 & 68.1 & 17.9 & 70 & 18 \\
\hline Ohio 6 & 254,256 & 78.4 & 8.2 & 78 & 8 \\
\hline Pitt. Seam & 259 & 74 & 8.9 & 78 & Not Stated \\
\hline Wyoming & $251-$ II & 61.0 & 3.9 & 63 & 10 \\
\hline Wyoming & $251-$ III & 60.2 & 10.9 & 62 & 10 \\
\hline TX Lignite & 255 & 50.1 & 21.4 & 50 & 23 \\
\hline
\end{tabular}

In the table above, organic rejection is the amount of organic matter rejected with the ash concentrate stream from the deasher. The table compares actual measured yields and organic rejections with projected yields at a specific level of organic rejection. Distillate 
yields of about $70 \%$ MAF coal were obtained with Illinois 6 coal, a yield of $78 \%$ MAF was obtained with Ohio $6 \mathrm{coal}$, and yields of over $60 \% \mathrm{MAF}$ were obtained with subbituminous coal. ${ }^{5}$ Complete process yields for representative steady-state periods of various runs are shown in Table 6-3.

For the most part, the best performance with bituminous coal was obtained with supported catalyst in both reactors and the best performance with subbituminous coal was obtained with supported catalyst in the second-stage reactor only, but with dispersed catalyst addition to the first stage. An active catalyst, usually a supported catalyst, was essentially required in the second stage in all operating variations in order to maintain product quality; otherwise, lower-quality "thermal" products were generated as net products. With subbituminous coal, the dispersed molybdenum catalyst improved the kinetics for both coal and resid conversion in the first stage, allowing operation at lower reactor temperatures and resulting in reduced gas make and improved selectivity for distillate production. ${ }^{6}$ In fact, the hybrid system with subbituminous coal gave higher distillate productivity, in terms of $\mathrm{lb} / \mathrm{h} / \mathrm{ft}^{3}$ of reactor volume, than that obtained with bituminous coals, even though distillate yield as a percent of feed coal was much lower for the subbituminous coals. The dispersed molybdenum catalyst also resulted in less solids build-up in process lines, ${ }^{6}$ a frequent operating problem with subbituminous coal; it is not clear whether the improvement is a direct effect of the catalyst or resulted from the reduced operating temperature that the catalyst permitted. A portion of Run 263 was operated with supported molybdenum and iron oxide catalyst, but no supported catalyst in either reactor; operations were acceptable in this mode, but the product hydrogen content was reduced and product heteroatom content was increased in the total absence of supported catalyst. ${ }^{7}$ However, adding dispersed molybdenum catalyst did not further improve product quality relative to that obtained with supported catalyst in the second stage ${ }^{6}$ in other words, product quality was the same for the hybrid and the thermal/catalytic operating modes.

The impact of coal cleaning on process yields was shown in Runs 254 and 256 with Ohio $6 \mathrm{coal}^{8}$ and in Run 259 with Pittsburgh Seam coal. Lower ash coal substantially improved distillate yield, primarily by reducing organic matter rejection (both on an MAF coal basis) 
from the deasher. Clearly, low-ash coal is the preferred feedstock, in terms of process yields, for liquefaction.

\section{Product Quality}

The qualities of distillate oils from representative tests with different feed coals are shown in Table 6-4. All the oils shown are free of vacuum resid (therefore, essentially free of metals and ash), and contain only very low levels of sulfur and substantially reduced levels of nitrogen. The crude product contains 11 to $13 \%$ hydrogen and the naphtha fraction contains about $14 \%$ hydrogen. It is noteworthy that the various feed coals shown produce distillates of reasonably similar quality. Nevertheless, the distillates from subbituminous coal contain distinctly greater concentrations of paraffins than those produced from bituminous coals. Detailed inspection of net products from Wilsonville CC-ITSL Runs 259 (Pittsburgh Seam coal) and 260 (Wyoming subbituminous coal) were reported elsewhere ${ }^{9,10}$. Those

inspections lead to the conclusion that CC-ITSL oils, although not finished transportation fuels, would make suitable blendstocks for producing transportation fuels in conventional petroleum refineries. Southwest Research Institute studied options for refining the crude product to finished fuels.

\section{Process Operability}

Throughout the CC-ITSL program, the operability of the pilot plant was good with bituminous coal. Operations with subbituminous coal and lignite tended to be more problematic. Solids tended to deposit in the interstage separator and interstage piping during subbituminous coal tests. The solids were often composed of semi-coke, calcite, pyrrhotite. The severity of the deposition problems, particularly of those in the piping, was reduced in Runs 262 and 263 , both of which used dispersed molybdenum catalyst. The overall on-stream factor for the reaction section of the pilot plant during the CC-ITSL program was $85.8 \%$.

\section{Process Economics}

As described by Lumpkin, ${ }^{11}$ the advances made during the Wilsonville (and concurrent) programs resulted in a substantially improved economic outlook for direct liquefaction technology, as compared to earlier programs, such as $\mathrm{H}$-Coal. 


\section{Process Strategy Findings From the ITSL and CC-ITSL Programs}

The ITSL and CC-ITSL programs built on successful strategies learned in the earlier Lummus two-stage liquefaction program and the concurrent two-stage liquefaction program conducted at Hydrocarbon Research Inc. (later Hydrocarbon Technologies, Inc.). The goals of the program were to maximize the yield of reasonably high quality distillate product, because it was believed this would improve the economics of a commercial operation. In order to meet these goals, the successful strategy included:

- Distillate products should be taken only from a catalytic reactor; products from thermal reactors are of poor quality. Thus, the second-stage reactor must contain catalyst, and, for the sake of product quality, it should be a supported catalyst.

- A sharp separation must be made between the net product and the heavier recycle stream so that product is not contaminated with heavy products and so that desirable light oils are not recycled and allowed to crack to gases.

- By definition, the yield of distillate is limited by the yields of gas and resid (which mostly reports as ash concentrate at the Wilsonville system). Therefore, the strategy to maximize distillate yield is to minimize gas and resid make. The recycle oil should be composed, to the extent allowed by viscosity, of soluble resid and recycled solids; the distillate component of the recycle oil should be minimized. This maximizes distillate yield by maximizing resid conversion and by limiting the cracking of distillate to gas and simultaneously minimizes gas make. If there is insufficient resid generated to act as the recycle oil, this indicates that process severity (and thus gas make) is excessive and that reaction temperature or time should be reduced.

- Low-ash feed coal is desirable. Distillate yield is substantially reduced as feed coal ash increases because of resid product that must be removed with the ash.

- The CC-ITSL process is flexible enough to convert a wide range of U.S. coals to distillate products in high yield and those distillate products are suitable to act as blendstocks for conventional petroleum refineries. 
- Low-rank coals yield less distillate per ton, even on an MAF basis, than bituminous coals because of their high oxygen contents. However, low-rank Powder River Basin coals can generate very high distillate productivity rates, $\mathrm{lb} / \mathrm{h} / \mathrm{ft}^{3}$ of reactor volume.

- The rate of conversion of bituminous coal into distillates is limited by the slow conversion of soluble resid. The soluble resid of subbituminous coals converts more easily than that of bituminous coals, but subbituminous coals are more difficult to convert to solubles in the first place. These relative differences mandate somewhat different processing schemes for the two groups of coals. For example, it is desirable to use supported catalysts in both reactors for bituminous coals. Subbituminous coals can suitably be processed with supported catalyst in only the second stage and with dispersed catalyst.

- For subbituminous coals, interstage separation of gases may be desirable to avoid wasteful methanation of carbon oxides in the second stage.

- The CC-ITSL process appears to be relatively insensitive to the ability of the recycle solvent to act as a hydrogen donor. Thus, the CC-ITSL process is relatively free of the requirement of good "solvent quality" that is inherent in donor-solvent processes.

- Differences in the activities among the various supported catalysts tested in the CCITSL program had only a minor impact of process performance; therefore, it can be concluded that, given acceptable hydrodynamic and physical properites, a range of supported catalyst formulations provides suitable activity.

- The dispersed molybdenum catalysts that were tested were actually produced to be lubricant additives, not catalysts. Nevertheless, they were effective for processing subbituminous coal.

- The activity of the supported catalysts tested is not substantially degraded by recycling solids. Solids recycle is beneficial because it maximizes the conversion of the solids, 
it allows for recycle of dispersed catalysts, and it reduces the amount of material needed to be processed by the deashing section.

- The CC-ITSL process, as tested at the 6 ton/d scale, is an operable and controllable process.

\section{References for Chapter 6}

1. Southern Electric International, Inc., Technical Reports Issued Under DOE Contract No. DE-AC22-90PC90033, in particular "Advanced Coal Liquefaction Research and Development Facility, Wilsonville Alabama, Final Report, Volume 1, Close-Coupled Integrated Two-Stage Liquefaction Process" draft report released 1993.

2. Southern Electric International, Inc., and Catalytic, Inc., Technical Reports Issued Under DOE Contract Nos. DE-AC22-82PC50041.

3. Nalitham, R.V.; Lee, J.M.; Lamb, C.W. "Two-Stage Coal Liquefaction Process Performance with Close-Coupled Reactors" Fuel Proc. Technol. 1987, 17, 13-27.

4. Nalitham, R.V.; Lee, J.M.; Davies, O.L.; Pinkston, T.E.; Jeffers, M.L.; Prasad, A. "Catalytic Close-Coupled Two-Stage Liquefaction Process Development with a Bituminous Coal" Fuel Proc. Technol. 1988, 18, 161-183.

5. Lee, J.M.; Cantrell, C.E. "Effect of Coal Rank and Quality on Two-Stage Liquefation" Fuel Proc. Technol. 1991, 29, 171-197.

6. Lee, J.M.; Vimalchand, P.; Davies; O.L.; Cantrell, C.E. "Performance of Hybrid Catalyst System in Two-Stage Coal Liquefaction" Am. Chem. Soc. Div. Fuel Chem. Prepr. 1992; vol. 37, No. 4; 1886-94.

7. Vimalchand, P.; Lee, J.M.; Davies; O.L.; Cantrell, C.E. "Dispersed Molybdenum Catalyst Tests with Black Thunder Mine Subbituminous Coal", Proceedings of the DOE Direct Liquefaction Contractors' Review Conference, Pittsburgh, PA, September 22-4, 1992.

8. Gollakota, A. V.; Lee, J. M.; Davies, O. L. "Process Optimization of Close-Coupled Integrated Two-Stage Liquefaction by the Use of Cleaned Coals", Fuel Proc. Technol. 1989, 22, 205-216.

9. Kramer, R. L. "Modified Crude Oil Assay of Wilsonville Run 259G Net Products" in Report DOE/PC89883-24, June 1991.

10. Kramer, R. L. "Modified Crude Oil Assay of Wilsonville Run 260D Net Products" in Report DOE/PC89883-34, November 1991. 
11. Lumpkin, R. E. "Recent Progress in Direct Liquefaction of Coal" Science 1988, 239, 837-952. 
TABLE 6-1. WILSONVILLE OPERATING CONDITIONS

2nd o. Cat Stace

1st or Thermal Stage

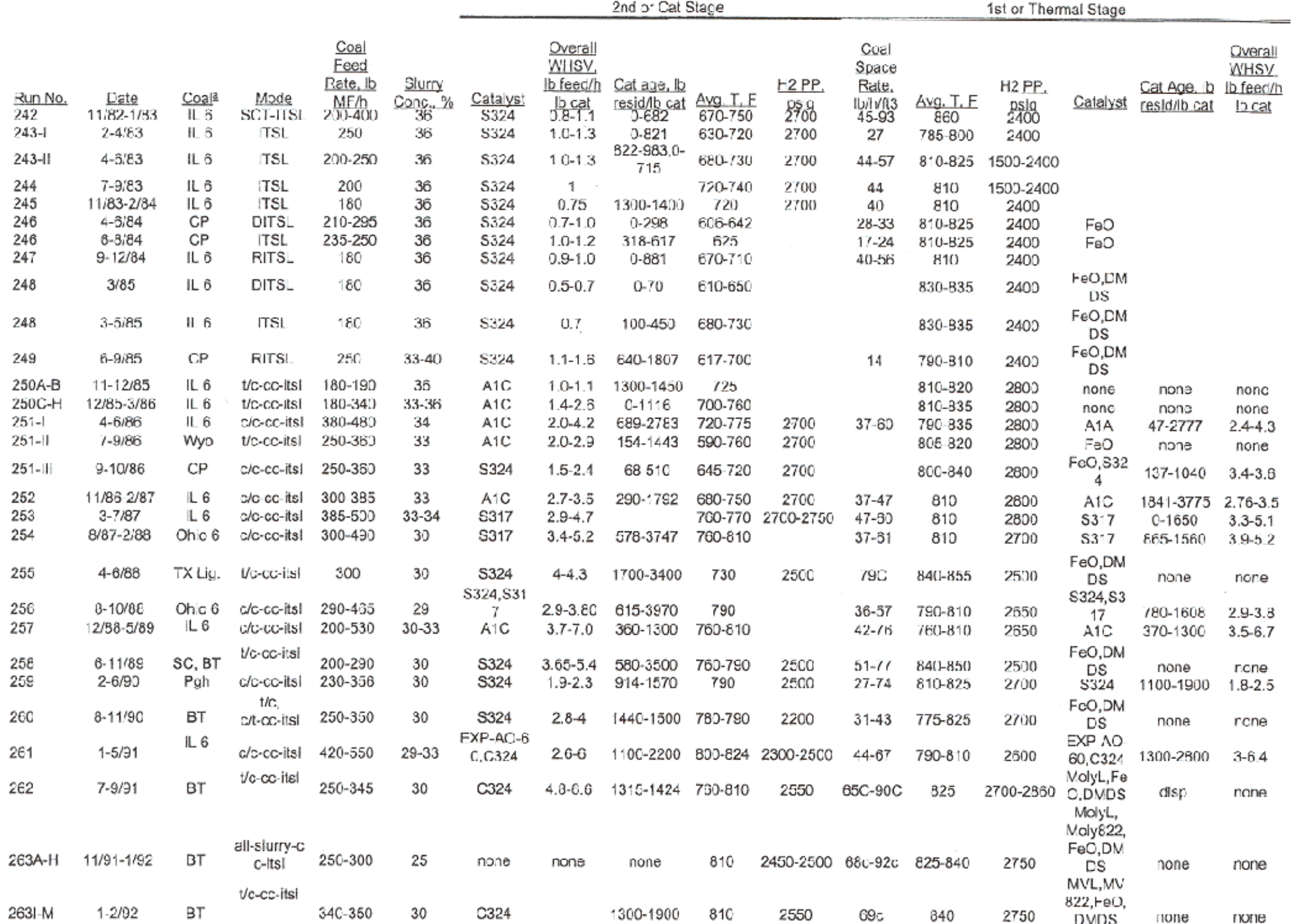

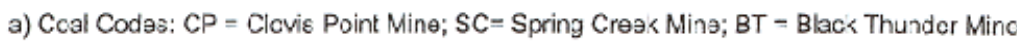


Table 6-2. Feed Coal Analyses

\begin{tabular}{|c|c|c|c|c|c|c|c|c|c|}
\hline & $\begin{array}{c}\text { Illinois } 6, \\
\text { Burning Star } 2 \\
\text { Mine }\end{array}$ & $\begin{array}{l}\text { Ohio 6, } \\
\text { Crooksville } \\
\text { Mine }\end{array}$ & $\begin{array}{l}\text { Ohio 6, } \\
\text { Holmes Mine }\end{array}$ & $\begin{array}{l}\text { Pgh Seam, } \\
\text { Ireland Mine, } \\
\text { mine-washed }\end{array}$ & $\begin{array}{l}\text { Pgh Seam, } \\
\text { Ireland Mine, } \\
\text { deep-cleaned }\end{array}$ & $\begin{array}{l}\text { Wyoming PRB, } \\
\text { Clovis Point } \\
\text { Mine }\end{array}$ & $\begin{array}{c}\text { Montana PRB, } \\
\text { Spring Creek } \\
\text { Mine }\end{array}$ & $\begin{array}{c}\text { Wyoming PRB, } \\
\text { Black Thunder } \\
\text { Mine }\end{array}$ & $\begin{array}{l}\text { TX lignite, } \\
\text { Martin Lake } \\
\text { Mine }\end{array}$ \\
\hline moisture, \% & 4.69 & 3.42 & 4.73 & 2 & 1 & 21.90 & 21 & 24 & 32.32 \\
\hline ash, \%MF & 11.54 & 6.59 & 6.24 & 14.7 & 4.7 & 8.08 & 5.7 & 7.3 & 11.39 \\
\hline $\begin{array}{l}\text { Vol. Matter, } \\
\text { \%MF }\end{array}$ & 37.78 & 40.14 & 40.16 & 39 & 43 & 46.73 & 42 & 44 & 44.11 \\
\hline $\begin{array}{l}\text { Fixed Carbon, } \\
\% \mathrm{MF}\end{array}$ & 50.68 & 53.27 & 53.60 & 46 & 52 & 45.19 & 52 & 49 & 44.50 \\
\hline $\mathrm{C}, \% \mathrm{MF}$ & 70.62 & 75.34 & 75.25 & 69.8 & 77.4 & 66.87 & 71.3 & 69.5 & 65.93 \\
\hline $\mathrm{H}, \% \mathrm{MF}$ & 4.83 & 5.32 & 4.93 & 4.8 & 5.7 & 4.92 & 5.1 & 5.1 & 4.39 \\
\hline $\mathrm{N}, \% \mathrm{MF}$ & 1.45 & 1.40 & 4.52 & 1.1 & 1.3 & 0.91 & 1.0 & 1.0 & 1.03 \\
\hline $\mathrm{S}, \% \mathrm{MF}$ & 3.35 & 2.63 & 3.19 & 4.5 & 3.1 & 0.93 & 0.5 & 0.6 & 1.22 \\
\hline Pyritic S, \%MF & 1.06 & 1.54 & 1.15 & 2.3 & 0.6 & 0.11 & 0.1 & 0.1 & 0.14 \\
\hline Sulfate S, \%MF & 0.12 & 0.02 & 0.03 & & & 0.12 & & & 0.03 \\
\hline O, \%MF (diff) & 8.03 & 8.70 & 8.74 & 5.0 & 7.8 & 18.26 & 16.4 & 16.5 & 16.03 \\
\hline $\begin{array}{l}\text { Heating Value, } \\
\text { Btu/lb MF }\end{array}$ & 12600 & 13300 & 13700 & 12600 & 14100 & 11200 & 12200 & 11800 & 11900 \\
\hline $\begin{array}{l}\text { Vitrinite } \\
\text { Refelct., \% }\end{array}$ & 0.53 & 0.59 & 0.64 & & & 0.40 & & & 0.28 \\
\hline Vitrinite, vol\% & 89.0 & 90.2 & 82.5 & & & 65.0 & & & 86.3 \\
\hline Liptinite, vol\% & 5.1 & 6.5 & 5.9 & & & 26.0 & & & 2.5 \\
\hline Inertinite, vol\% & 5.9 & 3.3 & 11.6 & & & 9.0 & & & 11.2 \\
\hline Reactives,vol\% & 94.1 & 96.7 & 88.4 & 92 & 93 & 91.0 & 96 & 92 & 88.8 \\
\hline
\end{tabular}


Table 6-3. Process Yields for Selected Steady-State Run Periods

\begin{tabular}{|c|c|c|c|c|c|c|}
\hline Yield, wt $\%$ MAF & $\begin{array}{l}\text { Illinois } 6 \text { coal, Run } \\
257 \mathrm{H}\end{array}$ & Ohio 6 coal, Run 256E & $\begin{array}{l}\text { Pitt. Seam coal, Run } \\
\text { 259G }\end{array}$ & $\begin{array}{l}\text { Wyoming coal, } \\
\text { supported catalyst, } \\
\text { Run } 258 \mathrm{I}\end{array}$ & $\begin{array}{l}\text { Wyoming coal, all- } \\
\text { slurry catalyst, Run } \\
263 \mathrm{H}\end{array}$ & $\begin{array}{l}\text { Wyoming coal, hybrid } \\
\text { catalyst, } 263 \mathrm{~J}\end{array}$ \\
\hline hydrogen consumption & $-6.4 / 0.1$ & $-6.5 / 0.1$ & $-6.8 / 0.1$ & $-5.9 / 0.2$ & $-5.6 / 0.3$ & $-5.8 / 0.2$ \\
\hline water & $7.4 / 0.8$ & $10.9 / 0.3$ & $6.5 / 0.6$ & $12.7 / 1.0$ & $14.4 / 0.9$ & $14.9 / 0.8$ \\
\hline $\mathrm{H}_{2} \mathrm{~S}, \mathrm{CO}, \mathrm{CO}_{2}, \mathrm{NH}_{3}$ & $5.0 / 0.2$ & $3.0 / 0.0$ & $4.5 / 0.1$ & $8.0 / 0.6$ & 4.7 & 7.0 \\
\hline $\mathrm{C}_{1}-\mathrm{C}_{3}$ Gas & $5.9 / 0.4$ & $7.3 / 0.2$ & $8.6 / 0.3$ & $10.3 / 0.7$ & $9.4 / 1.0$ & $7.9 / 0.8$ \\
\hline Total Distillate & $68.1 / 1.0$ & $68.4 / 1.5$ & $63.0 / 3.4$ & $58.1 / 1.7$ & $60.9 / 2.7$ & $58.4 / 1.3$ \\
\hline $\mathrm{C}_{4}-350^{\circ} \mathrm{F}$ & $19.2 / 2.0$ & $17.6 / 0.6$ & $23.8 / 2.1$ & $18.0 / 1.0$ & 11.7 & 15.2 \\
\hline $350-450^{\circ} \mathrm{F}$ & $7.8 / 0.8$ & $7.9 / 0.1$ & $9.4 / 0.2$ & $11.1 / 0.3$ & $10.3 / 0.8$ & $8.3 / 0.5$ \\
\hline $450^{\circ} \mathrm{F}$ - end point & $41.1 / 2.8$ & $42.9 / 1.0$ & $29.9 / 1.5$ & $29.0 / 2.8$ & $38.9 / 3.1$ & $35.0 / 1.5$ \\
\hline Resid & $2.2 / 1.3$ & $7.9 / 1.8$ & $13.4 / 2.6$ & $2.6 / 0.9$ & $2.4 / 1.8$ & 4.2 \\
\hline Ash-Free Ash Concentrate & $17.9 / 0.8$ & $9.0 / 0.5$ & $9.7 / 1.6$ & $14.2 / 0.7$ & $13.8 / 0.6$ & $13.4 / 0.3$ \\
\hline
\end{tabular}

Format shows the determined yield/uncertainty. 
Table 6-4. Distillate Properties From Wilsonville CC-ITSL Operations

\begin{tabular}{|c|c|c|c|c|c|}
\hline & $\begin{array}{l}\text { Illinois } 6 \text { Coal, } \\
\text { Run 261D }\end{array}$ & $\begin{array}{l}\text { Ohio } 6 \text { Coal, } \\
\text { Run } 254 \mathrm{G}\end{array}$ & $\begin{array}{l}\text { Pittsburgh Seam Coal, } \\
\text { Run 259D }\end{array}$ & $\begin{array}{l}\text { Wyodak Coal, } \\
\text { Run 260D }\end{array}$ & $\begin{array}{l}\text { Wyodak Coal, } \\
\text { Run 263J }\end{array}$ \\
\hline \multicolumn{6}{|c|}{ Total Distillate } \\
\hline $\mathrm{C}$ & 87.5 & 88.3 & 86.7 & 87.1 & 86.3 \\
\hline $\mathrm{H}$ & 11.3 & 11.3 & 12.0 & 11.1 & $\overline{11.0}$ \\
\hline $\mathrm{N}$ & 0.3 & 0.3 & 0.2 & 0.5 & 0.6 \\
\hline $\mathrm{s}$ & $<0.1$ & $<0.1$ & $<0.1$ & $<0.1$ & $<0.1$ \\
\hline $\mathrm{O}$ & 0.9 & 0.7 & 1.1 & 1.2 & 2.1 \\
\hline API & 22 & 19 & 26 & 22 & 22 \\
\hline \multicolumn{6}{|c|}{ Distillation yield, wt\% } \\
\hline $\mathrm{IBP}-350^{\circ} \mathrm{F}$ & 14 & 25 & 20 & 15 & 16 \\
\hline $350-450^{\circ} \mathrm{F}$ & 16 & 9 & 18 & 8 & 14 \\
\hline $450-650^{\circ} \mathrm{F}$ & 40 & 35 & 43 & 44 & 40 \\
\hline $650^{\circ} \mathrm{F}+$ & 30 & 32 & 19 & 33 & 30 \\
\hline end point, ${ }^{\circ} \mathrm{F}$ & 780 & 905 & 715 & 723 & 717 \\
\hline \multicolumn{6}{|l|}{ IBP - $350^{\circ} \mathrm{F}$} \\
\hline $\mathrm{C}$ & 84.5 & 86.0 & 83.4 & 85.1 & 84.5 \\
\hline $\mathrm{H}$ & 14.4 & 13.9 & 14.5 & 14.3 & 13.9 \\
\hline $\mathrm{N}$ & 0 & 0.1 & 0.2 & 0.1 & 0.2 \\
\hline $\mathrm{s}$ & 0 & 0.0 & 0.0 & 0.1 & 0.1 \\
\hline 0 & 0.1 & 0.0 & 1.9 & 0.4 & 1.3 \\
\hline API & 51 & 47 & 52 & 54 & 49 \\
\hline \multicolumn{6}{|l|}{$350-450^{\circ} \mathrm{F}$} \\
\hline $\mathrm{C}$ & 86.8 & 87.6 & 85.9 & 86.3 & 86.0 \\
\hline $\mathrm{H}$ & 12.3 & 12.0 & 12.4 & 12.0 & 11.7 \\
\hline $\mathrm{N}$ & 0.1 & 0.2 & 0.1 & 0.2 & 0.3 \\
\hline $\mathrm{s}$ & 0 & 0.0 & 0.0 & 0.1 & 0.0 \\
\hline $\mathrm{O}$ & 0.8 & 0.2 & 1.6 & 1.4 & 1.9 \\
\hline API & 29 & 24 & 30 & 29 & 25 \\
\hline \multicolumn{6}{|l|}{$450-650^{\circ} \mathrm{F}$} \\
\hline$C$ & 87.4 & 88.8 & 88.4 & 87.2 & 87.4 \\
\hline $\mathrm{H}$ & 11.3 & 10.9 & 11.5 & 10.9 & 10.6 \\
\hline $\mathrm{N}$ & 0.3 & 0.3 & 0.2 & 0.5 & 0.7 \\
\hline$S$ & 0 & 0.0 & 0.0 & 0.0 & 0.0 \\
\hline 0 & 1 & 0.0 & 1.9 & 1.4 & 1.3 \\
\hline API & 19 & 14 & 20 & 18 & 16 \\
\hline \multicolumn{6}{|l|}{$650^{\circ} \mathrm{F}+$} \\
\hline $\mathrm{C}$ & 88.9 & 90.0 & 89.0 & 88.3 & 88.5 \\
\hline $\mathrm{H}$ & 10 & 9.5 & 10.1 & 10.3 & 9.9 \\
\hline $\mathrm{N}$ & 0.4 & 0.5 & 0.2 & 0.6 & 0.9 \\
\hline$S$ & 0 & 0.0 & 0.0 & 0.0 & 0.0 \\
\hline 0 & 0.7 & 0.0 & 0.7 & 0.8 & 0.7 \\
\hline API & 9 & 7 & 10 & 11 & $\overline{9}$ \\
\hline
\end{tabular}




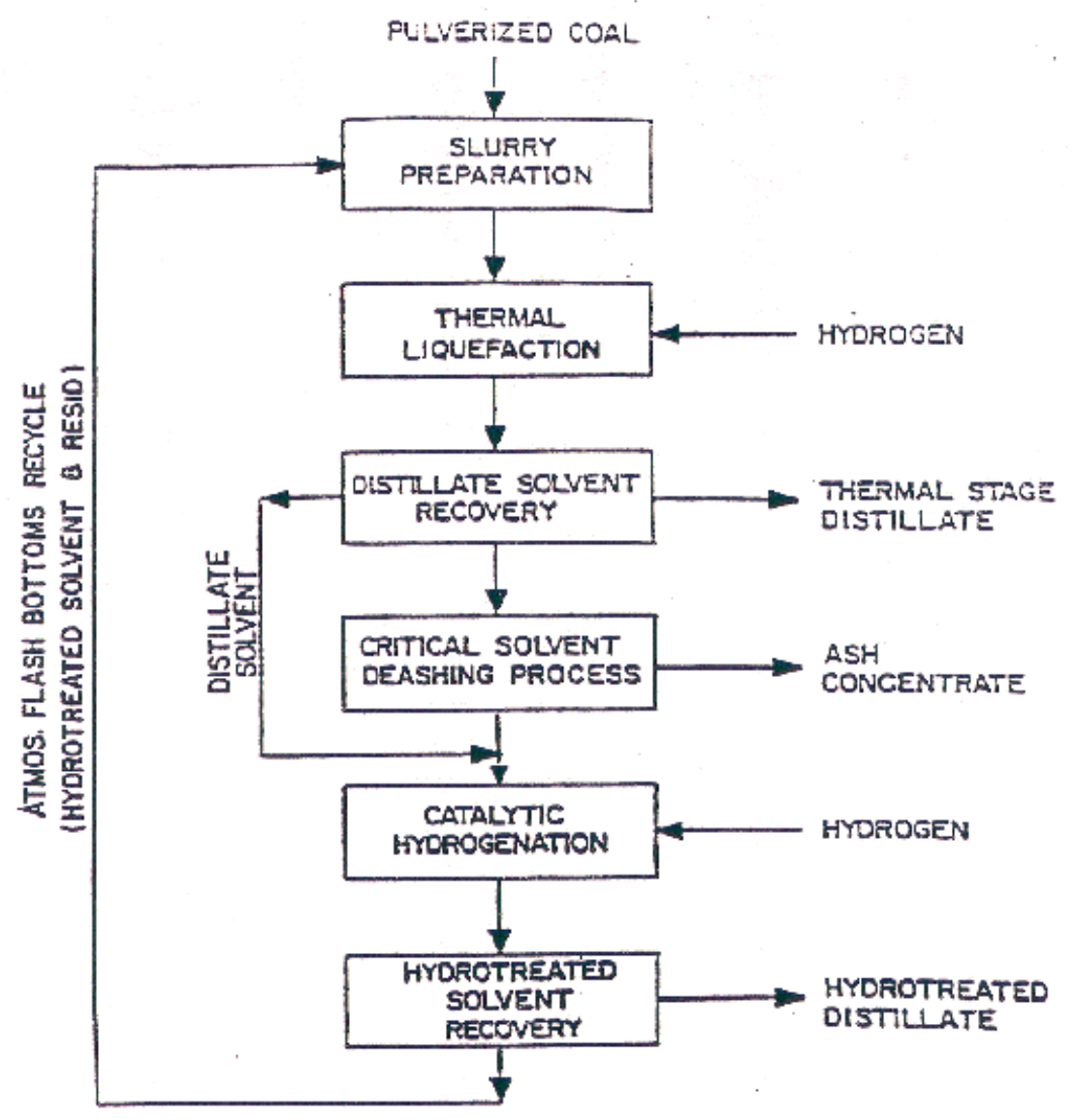

Figure 6-1. Block Flow Diagram of ITSL Operation. 


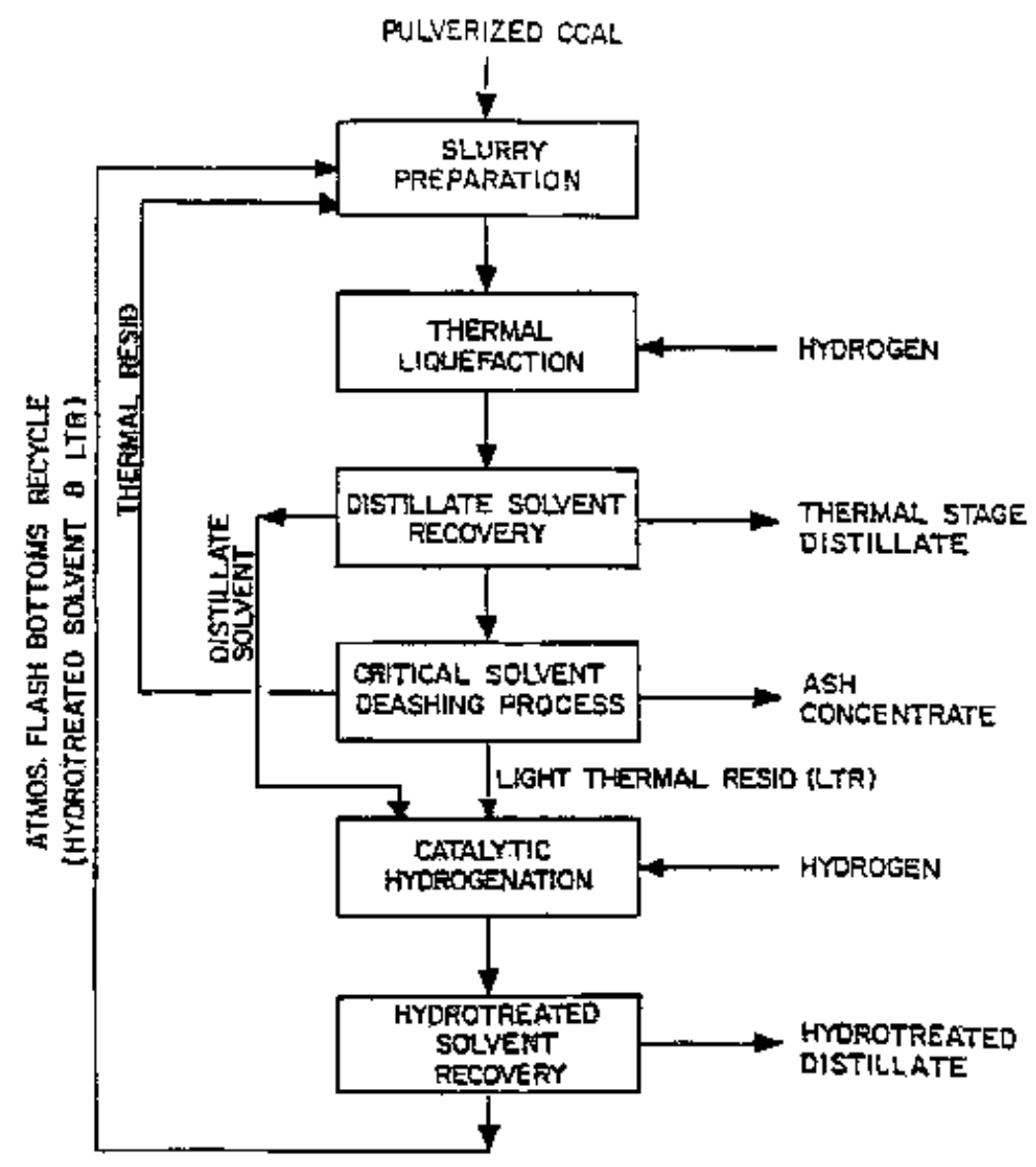

Figure 6-2. Block Flow Diagram of DITSL Operation. 


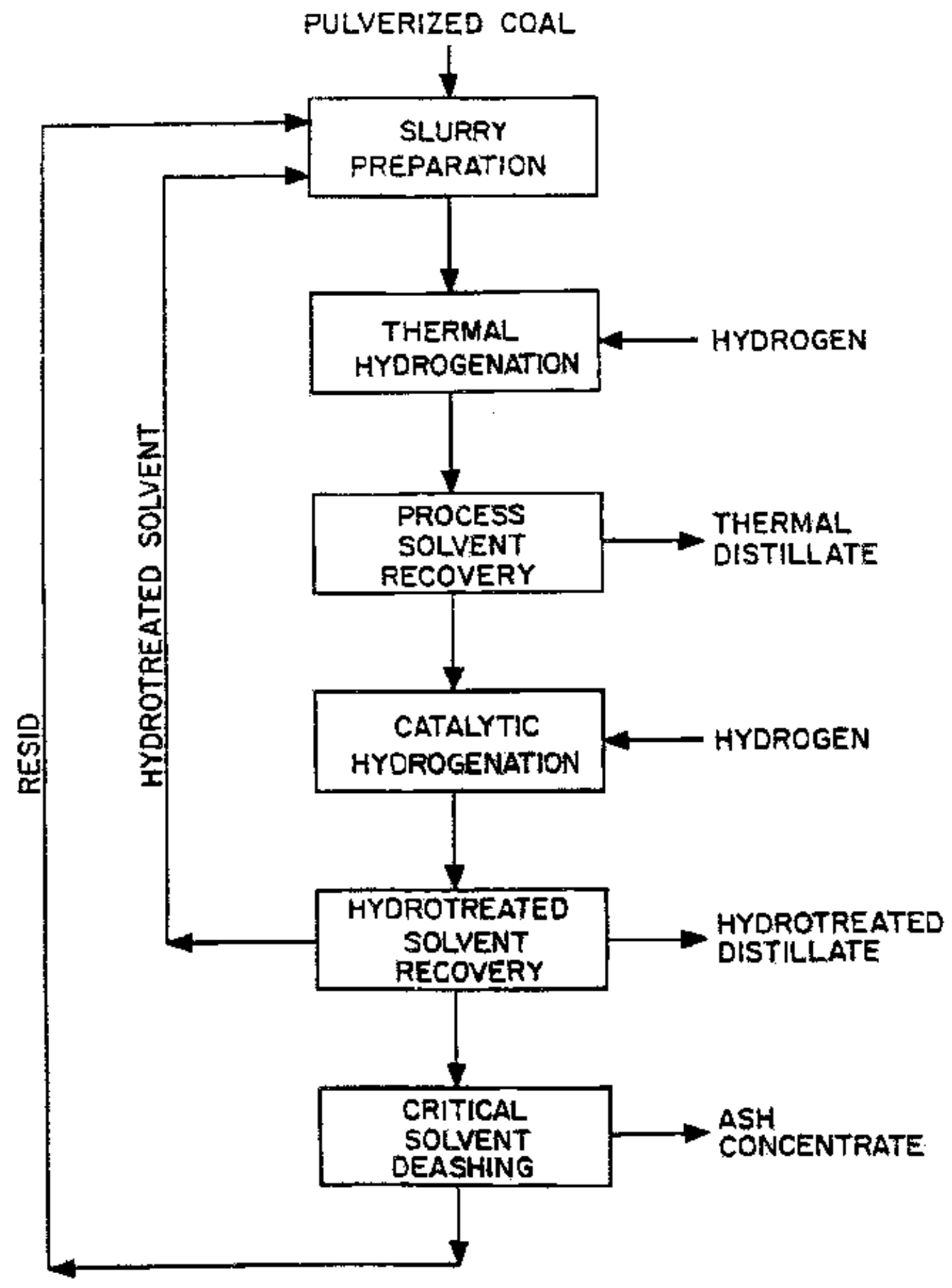

Figure 6-3. Block Flow Diagram of RITSL Operation. 


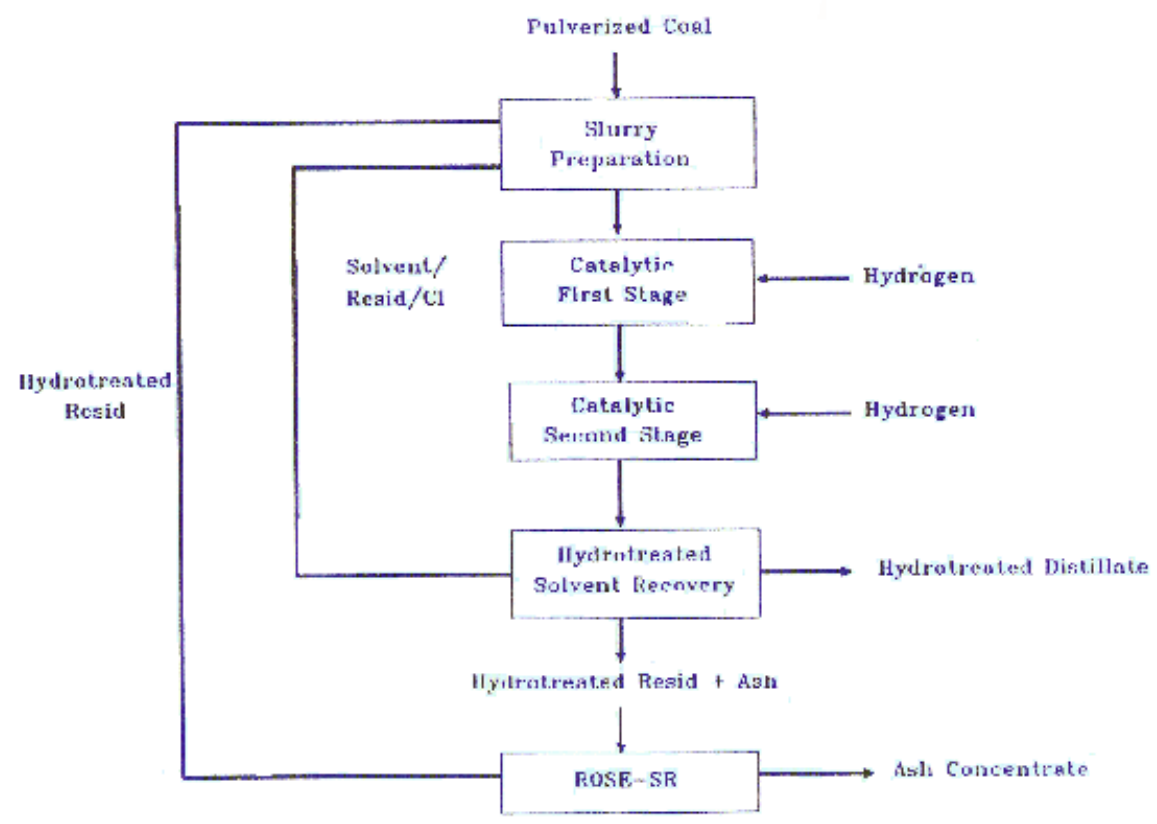

Figure 6-4. Block Diagram of CC-ITSL Process. 


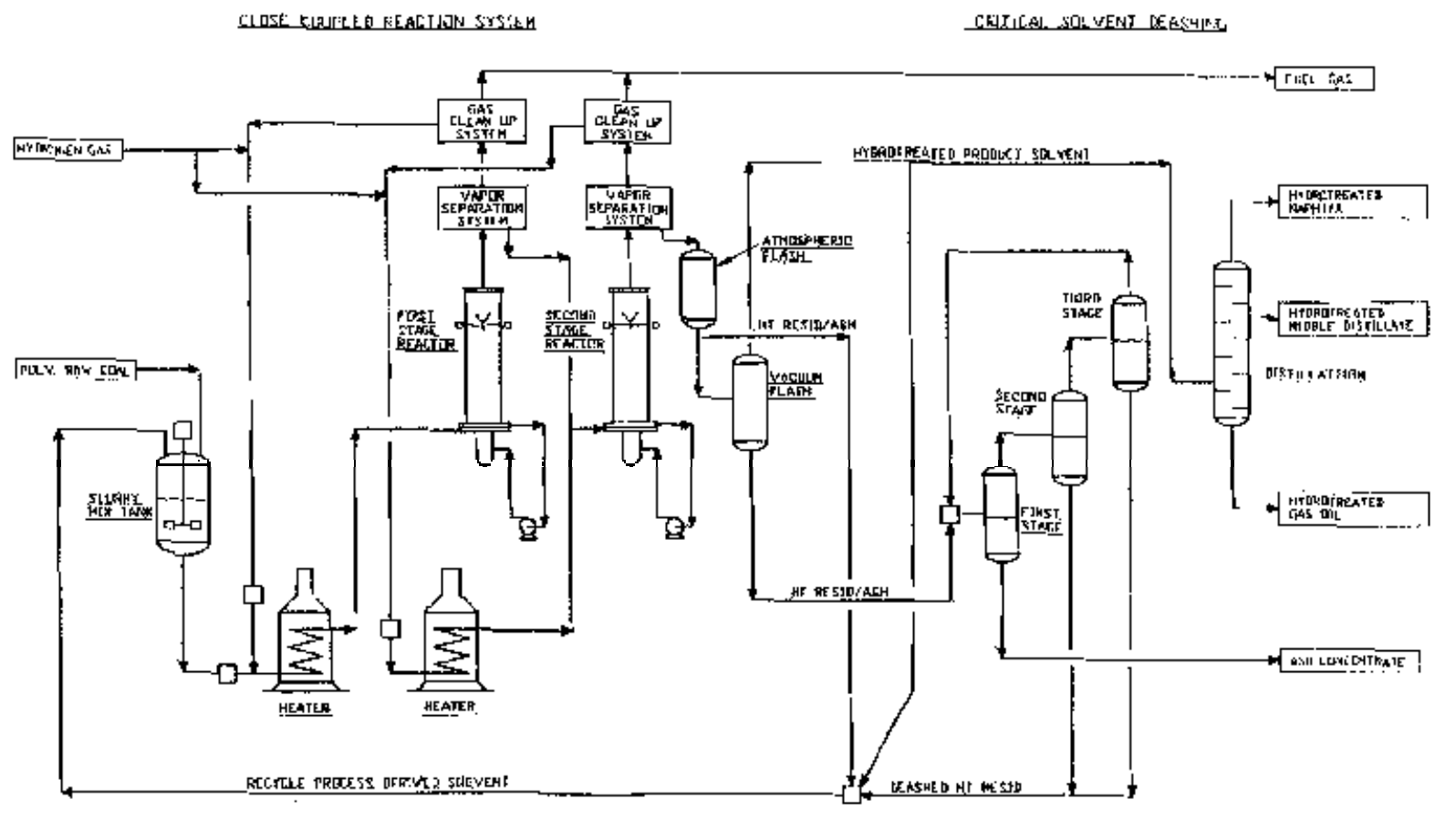

Figure 6-5. Schematic Flow Diagram of CCR Unit with Interstage Separation and Atmospheric Flash Bottoms Recycle. 


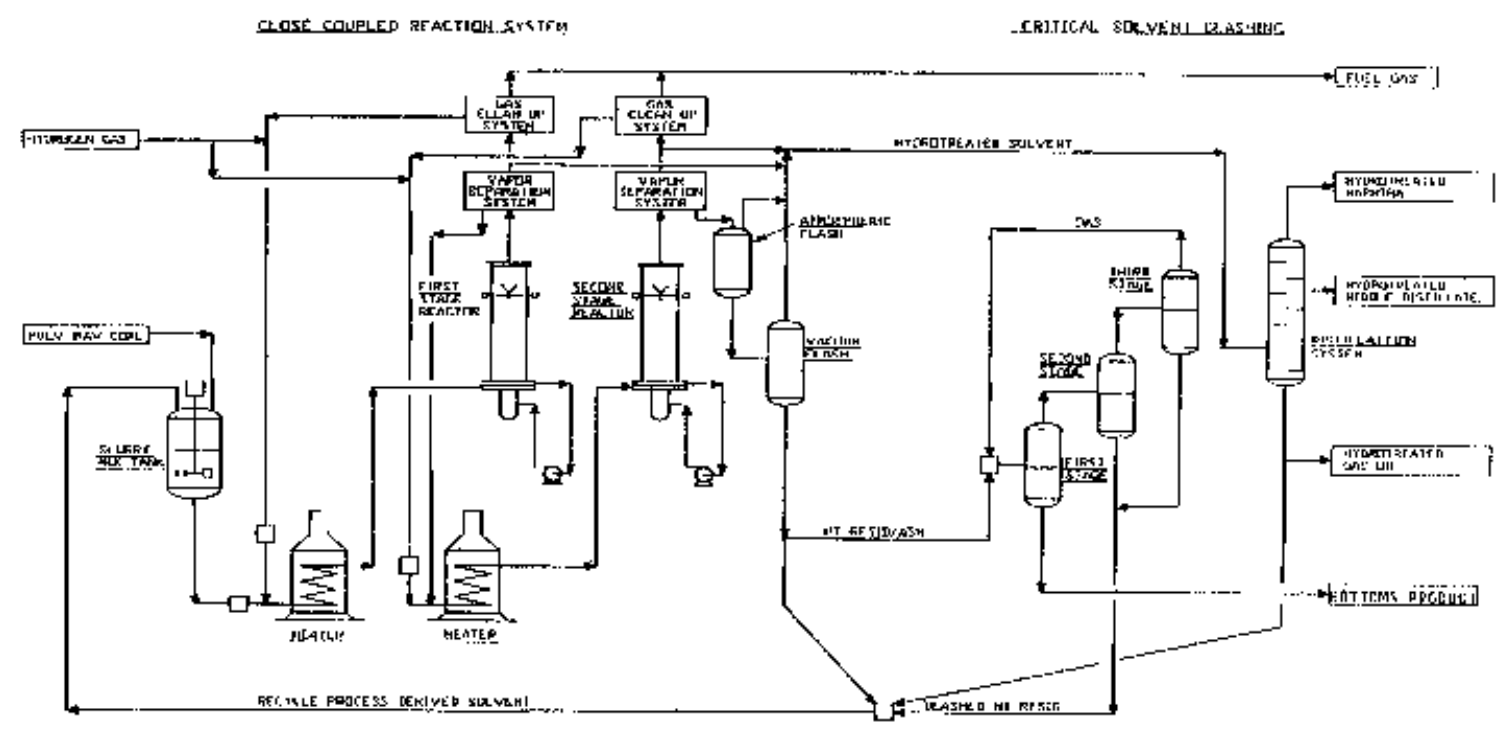

Figure 6-6. Simplified Flow Diagram of the Close-Coupled ITSL Coal Liquefaction System with Interstage Separation and With Vacuum Flash Bottom Recycle. 


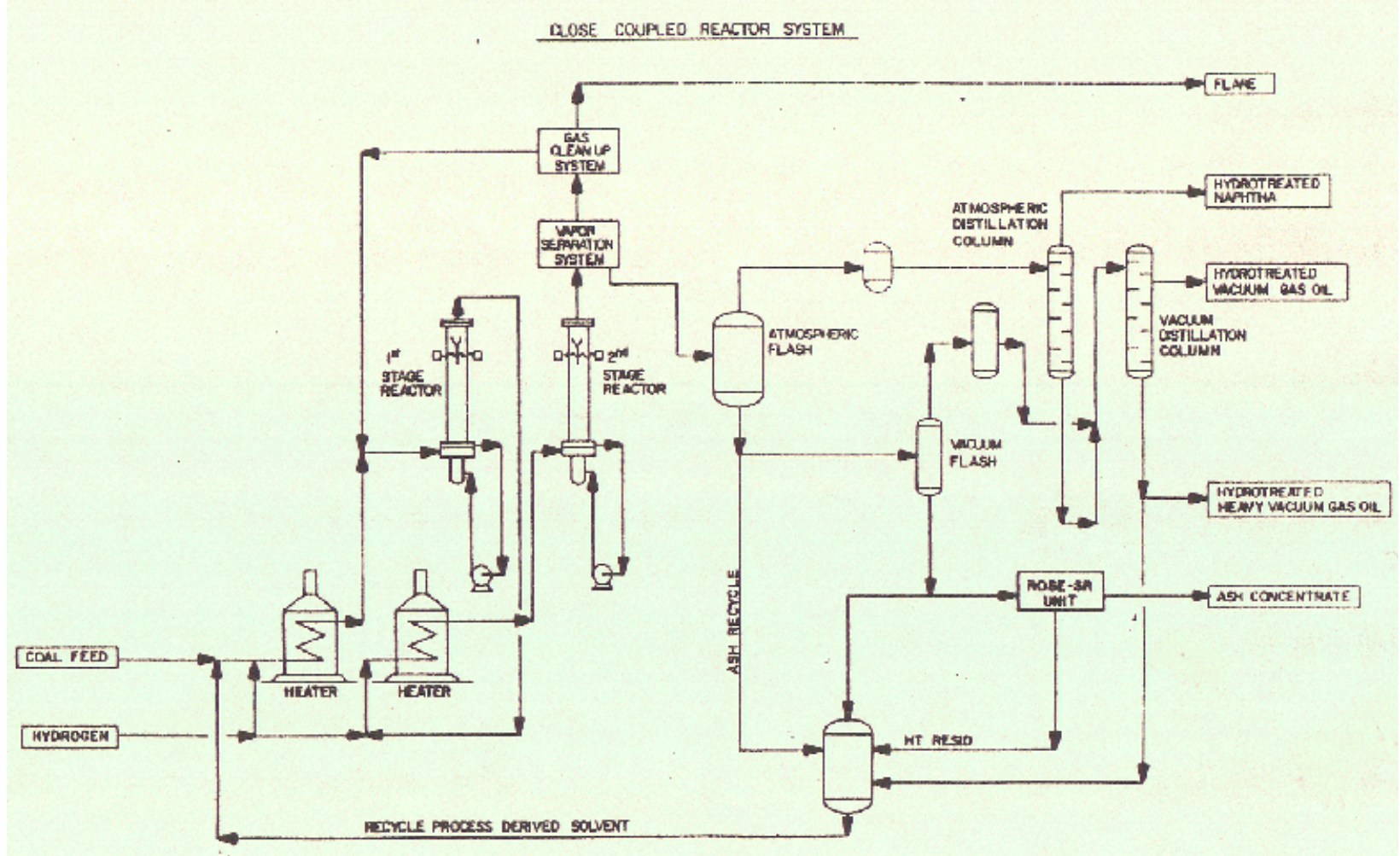

Figure 6-7. Simplified Flow Diagram of the Close-Coupled ITSL Coal Liquefaction System Without Interstage Separation and With Atmospheric Flash Bottoms Recycle. 


\section{Chapter 7}

\section{HYDROCARBON RESEARCH, INC./HYDROCARBON TECHNOLOGIES, INC. TWO-STAGE LIQUEFACTION PROGRAM}

\section{S. D. Brandes - CONSOL Energy Inc.}

\section{DESCRIPTION $^{1-4}$}

A catalytic two-stage (CTSL) process was developed by HRI, Lawrenceville, NJ, in 1982. The process evolved later into a multi-stage liquefaction technology under the development of Hydrocarbon Technologies, Inc. (HTI), Lawrenceville NJ. The two-stage process configuration is diagramed in Figure 7-1. The unit depicted is a nominal $50 \mathrm{lb} / \mathrm{day}$ bench unit (unit No. 227) consisting of two $2 \mathrm{~L}$ ebullated-bed reactors in series. A special highpressure, on-line sampling system was integrated with the first reactor. A continuous atmospheric still is integral to the process. The still provides accurate control of recycle solvent cut points. The atmospheric still bottoms are subjected to further batch filtration and/or vacuum distillation operations to study various recycle oil preparation techniques. System inventories are minimized to provide a rapid line-out response to condition changes. The two reactors were operated in several configurations with supported catalyst (thermal/catalytic, catalytic/thermal, and catalytic/ catalytic).

In 1993, the two-stage liquefaction system evolved into the catalytic multi-stage liquefaction (CMSL) system. The reactor configuration consisted of an initial pretreater stage, a backmixed slurry reactor, and an ebullated bed reactor. Dispersed catalyst precursors were activated in the pretreater. The first stage was operated as a slurry reactor with no supported catalyst. The second stage contained supported catalyst. Downstream of the second reactor, product separation was accomplished by a hot separator and a cold separator. The bottoms from the hot separator were further processed off line by batch pressure filtration. The pressure filter liquid (PFL) was used to slurry the feed coal. A diagram of the CMSL system is provided in Figure 7-2.

In addition to the bench unit described above, a $3 \mathrm{t} / \mathrm{d}$ process development unit (PDU) has also been employed at HTI. The PDU is shown in Figure 7-3. 


\section{CTSL}

\section{How CTSL Differs from H-Coal and DC-TSL}

In the two-stage catalytic process, coal is slurried with recycle oil, pressurized, mixed with hydrogen, and fed to the first stage ebullated-bed reactor. The first-stage temperature originally was maintained at $399 \mathrm{EC}$. This was a departure from $\mathrm{H}$-Coal where the reactor temperature was 443-452 EC. The lower temperature allows the coal to convert by dissolution in the recycle solvent at a slow rate. This allows the catalytic hydrogenation reactions, important for solvent regeneration and liquefaction product stabilization to keep pace with the rate of coal conversion. 3,5 This led to the recycle solvent being hydrogenated in situ and helped in maintaining its hydrogen donor potential. The lower first-stage temperature provides better overall hydrogen consumption management and reduced hydrocarbon gas yields as compared to the $\mathrm{H}$-Coal process.

The still-reactive asphaltenes and preasphaltenes formed in the first stage originally were passed directly to the higher-temperature (435-441 EC) second stage ebullated-bed reactor without any separation. The severity of the second stage can be regulated to control distillate and product selectivity.

The second-stage product streams from the CTSL process are much lighter than those produced in SCR-I, SRC-II, and H-Coal, allowing the use of pressure filtration to deash the products.

An overview of the process features that distinguished HRI's CTSL process from $\mathrm{H}$-Coal and direct-coupled two-stage liquefaction (DC-TSL) are provided in Table 7-1.

Improvements in process performance in the two-stage liquefaction process over singlestage $\mathrm{H}$-Coal performance were evident in the early tests. ${ }^{2}$ Higher distillate yields were obtained; $\mathrm{C}_{4}-524$ EC distillate yield was 65 wt \% MAF Illinois No.6, Burning Star Mine, bituminous coal. A $50 \%$ reduction in by-product gas make and a $50 \%$ reduction in residuum yield relative to $\mathrm{H}$-Coal was achieved. There was a $20 \%$ improvement in hydrogen efficiency, defined as the weight ratio of the distillate to the hydrogen consumed. An improved selectivity to mid-distillate boiling range products was achieved. There were some 
indications of improved heteroatom removal from the distillates. The distillates were more aliphatic than those produced previously in other liquefaction processes. In addition, the bottoms products were lower in viscosity. ${ }^{4}$

Additional early studies included liquefaction of Clovis Point Mine subbituminous coal, and Illinois No. 6, Burning Star Mine bituminous coal. ${ }^{3,4}$ The prime objectives of these studies were to improve distillation yields, improve hydrogen efficiency, and reduce catalyst deactivation rates.

The results from Run 227-27 made with subbituminous coal with catalyst aged 21 days are compared in Table 7-2 with results of a single-stage $\mathrm{H}$-Coal run and a test made with directcoupled, thermal-catalytic two-stage liquefaction made with a similar coal. Residuum conversion, distillate yield, and hydrogen efficiency are all greater for the CTSL process. Analysis of the distillates revealed that those produced in the CTSL process are more substantially hydrogenated.

\section{Catalysts}

The role of catalyst in the first stage of the CTSL process is to promote hydrogenation of the solvent, stabilization of the primary liquefaction products, and hydrogenation of the primary and recycle resid. In the second stage, the catalyst promotes heteroatom removal and thus product quality improvement, conversion of resid to distillate, secondary conversion to lighter products, and aids in avoiding dehydrogenation. ${ }^{7}$

In the almost twenty-year history of the CTSL and CMSL processes, a number of different catalysts were used to achieve these functions. In addition, catalysts were tested for activity and deactivation rate, and physical properties in the ebullated beds. Dispersed catalysts were tested in an effort to reduce operating costs and improve coal conversion to distillate.

Initial studies performed at HRI in the CTSL process used 1/16" extrudate CoMo catalyst Amocat $1 \mathrm{~A}$, which allowed fluidized catalyst operation over a wide range of viscosity and density. This was one catalyst developed for the $\mathrm{H}$-Coal process. However, because the 
reactor temperatures in CTSL were lower than those used for $\mathrm{H}$-Coal and because NiMo catalysts were known to have higher hydrogenation activity in the CTSL temperature range, Amocat $1 \mathrm{C}$ NiMo 1/16" catalyst was preferred for use in the first stage. Amocat $1 \mathrm{~A}$ continued to be used in the second stage for several demonstration runs. It was recognized that, in commercial operations, it could be desirable to use a single catalyst in both stages. Subsequently, Amocat $1 \mathrm{C}$ was tested for use in the second stage. It was concluded that the higher hydrogenation activity of the NiMo catalyst allowed the second stage to be operated at lower temperatures to produce the same distillate yields. In addition, the product quality was improved. Additional early tests employed a 1/32" extrudate of Amocat 1C, a spherical (12-14 mesh) NiMo catalyst (UOP RM-4), and 1/3" extrudate NiMo Shell S317. Comparison runs were made with the four different catalysts; yields are presented in Table $7-3 .^{7}$

Catalyst cascading was explored as a way to reduce overall catalyst use and cost. The spent catalyst from the first-stage was used in the second stage to take advantage of its remaining activity. The cascaded catalyst system achieved similar results to the use of fresh catalyst in both stages at a significantly higher overall catalyst age. ${ }^{7}$

Iron-molybdenum catalysts were investigated for use to liquefy subbituminous coal. Initially, an iron-molybdenum bead catalyst was tested and compared to the NiMo catalysts. ${ }^{16}$ Later, dispersed iron catalysts were used in combination with low-activity supported catalyst. ${ }^{17}$ An oxide (magnetite) and a pyrrhotite were used. $\mathrm{H}_{2} \mathrm{~S}$ gas was fed continuously to sulfide the catalyst. The magnetite additive (5 wt \%, coal basis) had little apparent effect on the total yield of distillate liquid product. The pyrrhotite additive ( $6 \mathrm{wt} \%$, coal basis) resulted in poorer performance than the magnetite additive. Higher gas yields and lower distillate yields were obtained.

A patented process to acid-wash supported catalyst was employed to "rejuvenate" a NiMo catalyst which was subsequently used in a test (CC-12) with Wyoming Black Thunder Mine subbituminous coal. ${ }^{19}$ The rejuvenation process lowered the catalyst crush strength by $30 \%$. However, $87 \%$ of the pore volume and $75 \%$ of the surface area were recovered. Compared 
to the fresh catalyst there was a minimal decline in residual oil conversion and an improvement in hydrogenation.

In 1991, HTI tested dispersed iron-oxide and molybdenum catalysts. ${ }^{19}$ A comparison was made with an Illinois No.6 coal impregnated with iron-oxide via an incipient wetness technique and an untreated coal with molybdenum dispersed as ammonium tetrathio molybdate (ATTM). Under the same conditions, $2800 \mathrm{ppm}$ of the iron oxide catalyst and $1500 \mathrm{ppm}$ of the ATTM produced similar process performance (coal conversion $94.6 \mathrm{wt} \%$ MAF coal and 94.5 wt \% MAF coal; hydrogen consumption 8.2 wt \% MAF coal and 8.1 wt \% MAF coal; $524 \mathrm{EC}^{+}$conversion 90.4 wt \% MAF coal and 89.5 wt \% MAF coal for the iron-oxide and the ATTM, respectively). Compared to a supported NiMo catalyst, the iron-oxide process operability was similar; however, the supported catalyst resulted in 1-2 wt \% MAF coal (abs) higher conversions.

Additional comparative tests were made with iron oxides using Black Thunder Mine subbituminous coal. ${ }^{23}$ In one case, the iron oxide was introduced in the form of a dry powder. In the second case, the iron oxide was impregnated on the coal by the incipient wetness technique developed by the U.S. DOE Pittsburgh Energy Technology Center (PETC) ${ }^{24}$ The impregnation raised the iron content of the coal from $0.2 \mathrm{wt} \%$ (dry basis) to $0.57-0.65$ wt \% (dry basis). The performance of the iron impregnated coal (about $5000 \mathrm{ppm} \mathrm{Fe}$ ) was measured in a thermal/catalytic mode of operation. The second stage contained presulfided Criterion $317 \mathrm{Ni} / \mathrm{Mo}$ catalyst. Tests were made with the iron oxide powder additive under the same mode of operation. Distillate yields were similar (59.0 and $60.2 \mathrm{wt} \%$ MAF coal basis) regardless of how the iron was introduced into the system.

In 1993, the impact of finely dispersed bi-metal catalysts, molybdenum and iron, on the liquefaction of Black Thunder Mine subbituminous coal was evaluated in thermal/catalytic mode of operations..$^{21,25}$ The iron catalyst was impregnated on the coal, resulting in an iron content of $6100 \mathrm{ppm}$. Molybdenum was added in the form of a pre-dissolved aqueous ammonium heptamolybdate solution to the feed slurry tank. The addition rate was the equivalent of $300 \mathrm{ppm}$ Mo. The highest coal conversions achieved to that date with Black Thunder Mine coal resulted from this catalyst combination (93.4-94.0 wt \%). The distillate 
yield was an acceptable 63.5-64.5 wt \% MAF coal. Significantly higher coal throughput ( $50 \%$ over a similar catalytic/catalytic test) resulted in only a $4.4 \mathrm{wt} \%$ reduction in distillate yield. In addition, the light distillates (IBP-650F) from the dispersed bi-metal operations utilizing on-line hydrotreating contained $10 \%$ as much nitrogen and $17 \mathrm{wt} \%$ more hydrogen than those of the catalytic/catalytic operations.

\section{Proprietary Catalysts}

$\mathrm{HTI}$ developed several proprietary dispersed iron catalysts. ${ }^{28}$ In microautoclave tests with these sulfate-modified iron-based catalysts, coal conversion based on THF solubility of a Back Thunder Mine subbituminous Wyoming coal were greater than that obtained at the same loadings (5000 ppm iron) with a commercially available dispersed iron catalyst (ca.8386 wt \% vs $76-81$ wt \%). The addition of a small amount of Mo (100 ppm) improved the conversion further (ca. 87-90 wt \%). In tests made in the CTSL system with the proprietary catalyst in both reactors (all-dispersed mode of operation) and Mo loadings of 50-100 ppm, coal conversion in the range of 93-96 wt \%, resid conversion of 83-92 wt $\%$ and $\mathrm{C}_{4}-524 \mathrm{EC}$ distillate liquid yields of 60-66 wt \% were obtained. ${ }^{28}$ The level of performance achieved was better than that obtained with any other catalyst system.

\section{Coal}

Two coals initially were used as feedstocks for CTSL runs: Illinois No. 6 Burning Star Mine bituminous coal and Powder River Basin (PRB) Clovis Point Mine subbituminous coal. The two coals behaved differently in the CTSL process and, thus, 'optimum' conversion conditions for each were different. ${ }^{5,9}$ A maximum conversion of $95-96$ wt $\%$ was typically achieved with Illinois No. 6 coal at first-stage temperatures of 399-413 EC. The PRB coal was much slower to undergo conversion and required the thermal severity of the second stage to achieve 90-93 wt \% conversion. ${ }^{5}$ The Illinois coal however, produced a much higher residuum yield than the PRB coal.

Deep-cleaned and mine-washed coal feeds were compared in the CTSL process. ${ }^{12}$ Illinois No. 6 Burning Star Mine bituminous coal with approximately $10 \mathrm{wt} \%$ ash was reduced in ash content by heavy media cleaning and conventional washing techniques (analyses are provided in Table 7-4). The cleaned coal samples were then subjected to the same 
liquefaction conditions. There was a small improvement $(2 \%$, abs) in coal conversion from deeper cleaning. However, the primary advantage of using a cleaned coal was projected to come in the capital and operating cost reductions associated with the solids separation operations of a commercial plant.

Other coal cleaning methods were investigated later in the program. ${ }^{17}$ Illinois No. 6 Burning Star Mine coal, ground to 50 mesh was cleaned using a heptane/asphalt agglomeration technique. As before, deeper cleaning of the coal resulted in an approximate $2 \%$ higher coal conversion than with the run-of-mine coal. A micronized coal (median particle diameter of $5 \mu \mathrm{m}$ ) containing $3.5 \mathrm{wt} \%$ ash (dry basis) was produced by OTISCA and was supplied as a $35 \%$ slurry in water. The water was removed to low levels prior to liquefaction. The recycle solvent/coal ratio had to be maintained above $1.7 / 1$ for successful pumping of the micronized coal in the CTSL bench unit. Coal conversion with the micronized coal was about $2 \%$ greater than that obtained with the uncleaned coal at similar operating conditions. Coal cleaned by electrostatic precipitation was prepared by Advanced Energy Dynamics (AED) using a proprietary process. The coal produced had an ash content of $4.9 \%$. With the electrostatically cleaned coal, coal conversions improved by about 3\% over the minewashed coal. An acid-leached coal prepared by Ash Lite Resource Engineering, Inc. also was tested. Few data were acquired using the Ash Lite prepared coal because it produced a high pressure drop in the bench unit after 13 continuous hours of operation. ${ }^{18}$

Extinction recycle tests (see below) were completed using heavy-media cleaned Illinois No. 6 Burning Star Mine coal and Ohio No. 5/6, Cravat Coal Co. bituminous coal.

Black Thunder Mine, Wyodak and Anderson Seam, Wyoming subbituminous coal was used later in the program. This coal was "referenced to" the extensive tests run previously in the program with the Clovis Point Mine sample of PRB subbituminous coal. ${ }^{16}$

To investigate the possible benefits of deoxygenation of coal as carbon oxides, tests were made in which slurries of the Black Thunder Mine coal and recycle solvent were preheated to $260-316$ EC for approximately six hours in a batch operation. ${ }^{17}$ The thermal pretreatment 
did deoxygenate the coal by the generation of carbon oxides. However, the treatment apparently depressed the liquid range products and not the light gas product.

\section{Extinction Recycle}

The feasibility of complete $343 \mathrm{EC}^{+}$oil extinction and conversion was demonstrated early in the program for both PRB and Illinois No. 6 coals. ${ }^{6}$ Corresponding $\mathrm{C}_{4}-343 \mathrm{EC}$ yields of $>70$ wt \% MAF coal were achieved. A simplified schematic of the heavy oil extinction recycle process is shown in Figure 7-2. In the bottoms extinction mode, all high boiling constituents of the product mix are recycled the reactors. A portion of the high-boiling materials become mixed with the solids in the filter cakes. An extraction process for separation of the product oils from the product solids was used. Oils and residua were extracted from filter cake using a toluene wash followed by distillation. Later, it was demonstrated that to reduce the commercial cost of the solvent-solids separation, the scale of the operation had to be reduced. To do this, the ash content of the feed was reduced by heavy-media cleaning. Extinction conversion of the $399 \mathrm{EC}^{+}$heavy oil products was demonstrated through integration of coal cleaning, product solids separation, and selective recycle with Illinois No. 6 and Ohio 5/6 bituminous coals. High temperature atmospheric distillation of recycle solvents at the maximum feasible temperature was used. A higher atmospheric cut point

was attained using a nitrogen stripping on the continuous atmospheric still. Yields of distillate oils of up to five barrels per MAF ton of coal were achieved. ${ }^{13}$

The Ohio coal operations also tested extinction of the vacuum gas oil (VGO) There was produced in this mode of operation a higher proportion of light distillate (Table 7-5).

\section{$\underline{\text { Temperatures }}$}

Process variable studies resulted in the following improvements and observed trends. Operating temperature ranges for both first- and second-stage reactors were established. It was found that first-stage temperatures below $371 \mathrm{EC}$ resulted in poor coal conversions. At 413 EC conversion improved, but product quality (hydrogenation efficiency) declined. Second-stage temperatures below 441 EC resulted in lower conversions without substantially improving hydrogen efficiency. Temperatures above $441 \mathrm{EC}$ reduced hydrogen efficiency and increased gas yields. 
Using the Black Thunder Mine subbituminous coal, a wide range of first- and second-stage temperature patterns was studied. In this work, the second-stage was operated at temperatures higher, lower, and equal to the first-stage temperature. A summary of the test is provided in Table 7-6. A detailed characterization of the products from the first and second stage indicated more aromaticity of products from the higher temperature first stage and an increase in preasphaltene concentration.

\section{Recycle Ratios}

Recycle solvent plays a transport role, as well as a role in coal solubilization and hydrogen transfer. The ratio of solvent-to-feed coal is an important parameter in the liquefaction process in that it has a direct impact on process unit size. Reduction of the solvent-to-feed coal ratio can result in improvements in the utilization of reactor volume and in reaction kinetics through increasing concentration of the reactants derived from the fresh feed.

The preferred recycle was solids-free at the minimum operable oil/solids ratio. Ratios as low as $1: 1$ were shown to be achievable in bench-scale operations. ${ }^{12}$ These low ratios were possible because of the low viscosity of the hydrogenated recycle oil and direct in-situ production of hydrogenated products in the first-stage catalytic reactor. Low solvent ratios, in addition to being more economic, gave improved performance for conversion and hydrogenation by increasing reactor residence time in both stages.

In 1993, Run CSML-02 explored lowering the solvent-to-coal ratio below 1.0. The feed coal for this run was Illinois No. 6 coal. At a ratio of 0.9 coal conversion was maintained at the level achieved in previous runs made at solvent-to-coal ratios of 1.1 and 1.59. In addition, distillate yields were higher and distillate content of lower boiling components was higher.

\section{Solids Separation}

Delayed coking was studied as a means to effect solids separation of the product slurry. ${ }^{17}$ The atmospheric still bottoms from a test (Run CC-9) made with micronized Illinois No. 6 coal were processed in a Foster Wheeler Development Corporation 4" diameter minicoker. Temperature and steam/feed ratio were selected as variables to maximize liquid yields. 
$85 \%$ of the liquid content of the feed was recovered and $30 \%$ of the $524 \mathrm{EC}^{+}$liquid was converted into $\mathrm{C}_{4}-524 \mathrm{EC}^{\mathrm{G}}$ net product.

British Coal examined slurries produced in the CTSL bench unit for filtration properties. ${ }^{20}$ Tests were conducted on a $0.11 \mathrm{~m}^{2}$ filter. Variables, such as filtration temperature, pressure, heat treatment, filter body aid, and others, were examined and optimized. It was determined that filter screens with apertures larger than the solids particle size can be successfully used (indicative of bridging behavior). A wash cycle with a distillate was necessary to recover the heavy oils trapped in the filter cake.

\section{$\mathrm{CO}_{2}$}

In one test, $\mathrm{CO}_{2}$ was used to transport the coal slurry to the reactor system. ${ }^{19}$ This resulted in a high conversion of Black Thunder Mine subbituminous coal (94 wt \% MAF coal). There was a concomitant shift to high gas make, shift to lighter distillates, and high hydrogen consumption. It was believed that the $\mathrm{CO}_{2}$ shifts to methane and water at the CTSL conditions.

\section{Synthesis Gas}

The production of hydrogen in the CTSL/CMSL system is one of the major cost constituents of the process. In an effort to minimize this cost factor, alternative sources of hydrogen, such as synthesis gas ( $\mathrm{CO}$ and $\mathrm{H}_{2}$ ), were tested. The synthesis gas could be obtained directly from a gasifier or steam reformer and would require a minimum of processing. The effects of substituting hydrogen with syngas in the CTSL system were determined. ${ }^{21}$ Distillate yield, coal conversion, and residuum conversion were higher. The first-stage separator overhead stream was of lower gravity and higher hydrogen content than when hydrogen was used as a reducing gas.

The mixture of $\mathrm{CO}$ and water was known to be effective in solubilizing low rank, high oxygencontent coal under mild conditions. It also was well known that alkali salts promote the formation of hydrogen from $\mathrm{CO} / \mathrm{H}_{2} \mathrm{O}$ by the water gas shift (WGS) reaction. However, for the CTSL system, because alkali salts can severely reduce the activity of the supported second-stage catalyst, non-alkali promoters were investigated. ${ }^{26,27}$ Five non-alkali pro- 
moters were screened in a $20 \mathrm{cc}$ microautoclave and ranked according to the degree of $\mathrm{CO}$ conversion. The relative activity ranking was: Amocat $1 \mathrm{~A}$, Shell $317>$ ammonium heptamolybdate $(\mathrm{AHM}) /$ dimethyl disulfide $>\mathrm{K}_{2} \mathrm{CO}_{3}, \mathrm{NaAlO}_{3}>>\mathrm{Fe}_{2} \mathrm{O}_{3}$. Two bench-scale tests were subsequently conducted. One test used AHM (CMSL-03) and the other (CMSL04) used Shell 317 supported catalyst as a WGS promoter. ${ }^{26,27}$ Conditions and process performance for the two runs are given in Table $7-7 .{ }^{26}$

\section{In-line Hydrotreating}

To improve product quality, in-line hydrotreating was demonstrated in the CTSL bench unit. ${ }^{19}$ The hydrotreater used a Shell 424 trilobe NiMo catalyst and the excess hydrogen exiting the reactor system. In tests with New Mexico McKinley Mine subbituminous coal, products were reduced in nitrogen contents from $1300-1600 \mathrm{ppm}$ to $9-89 \mathrm{ppm}$ and in sulfur concentrations from 230-240 ppm to 2-14 ppm. In addition, the product characterization showed that substantial aromatics saturation had occurred.

Later, the use of an in-line hydrotreater in Run CMSL- $05^{27}$ was demonstrated with Illinois No. 6 Crown II Mine bituminous coal with both hydrogen and syngas $\left(\mathrm{CO} / \mathrm{H}_{2} \mathrm{O}: 75 / 25\right)$ as a reducing gas. The products had $17-50 \mathrm{ppm}$ sulfur and $10 \mathrm{ppm}$ or less nitrogen.

\section{Scale-Up}

In 1992 the CTSL process was successfully scaled up from the $50 \mathrm{lb} / \mathrm{h}$ bench-scale unit to a 3 t/d process development unit (PDU). The PDU (Unit 260) is depicted in Figure 7-3. It uses the ebullated-bed reactor system. It is capable of operating at temperatures up to 865 EF and pressures up to 3000 psig. The PDU is a totally integrated coal and oil hydrogenation process development unit. It includes coal and residuum feed handling systems, coal preparation (screening and feeding), slurry mixing and pumping, preheating, reaction, product separations, atmospheric and vacuum fractionation, naphtha stabilization, bottoms handling, solid separation, product storage and data acquisition/storage and reporting capabilities. The successful filtration of the CTSL bench unit products ${ }^{20}$ led to the decision to install a $75 \mathrm{sq} f t$ vertical leaf U.S. Filter (along with the support equipment). This allowed the PDU to operate in the extinction recycle mode of operation. 
In 1993, the Department of Energy awarded to HRI a contract to conduct demonstrations of direct coal liquefaction in the $3 \mathrm{t} / \mathrm{d}$ PDU. This program was known as the Proof of Concept (POC) Program. ${ }^{22,29}$ The PDU was modified to incorporate an in-line hydrotreater, a new second-stage reactor and reactor structure, a ROSE-SR ${ }^{\mathrm{TM}}$ solid separation unit, a new pulverized coal storage and handling system, new preheaters, new flare system, and a computerized automated data collection and control system. A schematic of the modified PDU is given in Figures 7-3 and 7-4.

The POC program tests were based on prior bench scale or larger scale tests, such as those conducted at Wilsonville. The program was meant to emphasize longer term demonstrations rather than short term process variable studies. POC-1 was made with Crown II Mine Illinois No. 6 bituminous coal in slurry oil/coal ratios of $0.9-1.0$. Conclusions derived from Run POC-1 were the following. Extinction recycle can be achieved. A clean 57-352 EC distillate can be produced with hydrotreating space velocities up to $29 \mathrm{lb}$ MF coal $/ \mathrm{h} / \mathrm{ft}^{3}$. Coal conversion up to $96 \%$ and resid conversion over $85 \%$ was achieved. The Rose-SR unit efficiency is unaffected by the ash content of the recycle stream. Run POC-2 demonstrated the scale-up of the CTSL process with subbituminous coal. An important element of Run POC-2 was the co-processing of petroleum resid in the last run condition (see below).

\section{COPROCESSING}

\section{Coal/Oil}

Coal/oil co-processing was investigated with the CTSL reactor system at HRI beginning in 1985. It was believed that the potential benefits were the use of low-cost feedstocks (lowcost coal and poor-quality petroleum resid); lower capital investment in a commercial facility than one for direct coal liquefaction; use of existing petroleum refinery infrastructure; minimal commercialization time; production of environmentally and regulatory acceptable fuels; and the ability to provide operators with feedstock flexibility. ${ }^{32}$

Microautoclave screening tests were made with Ohio No.5 bituminous coal and Cold Lake petroleum residuum (399 EC+) obtained from Esso's Strathcona refinery. Conditions were $427 \mathrm{EC}, 30 \mathrm{~min}, 13.6 \mathrm{MPa} \mathrm{H}_{2}$, with a cobalt-molybdenum hydrotreating catalyst. These tests 
showed a synergistic effect at 33 and 50 wt \% coal and poorer than anticipated performance at 67 wt \% coal. Co-processing tests were made in the bench unit in both one-stage and two-stage modes of operation with the same feedstocks and with coal/oil ratios of $2 / 1,1 / 2$, and $1 / 1$. The synergy observed in the microautoclave tests was observed in the bench unit. Coal conversions of 91-96 wt \% MAF coal and $524 \mathrm{EC}^{+}$conversions of 70-92 wt \% MAF coal were obtained. ${ }^{32,33}$ Demetalation of the oil feed (99\% MAF coal) also was observed. The product quality (of the vacuum gas oil) was superior for the twostage operation. Denitrogenation ( $60 \mathrm{wt} \%$ ) and desulfurization ( $80 \mathrm{wt} \%$ ) of the coal was demonstrated.

Two additional oils and another coal were tested in co-processing mode. ${ }^{34}$ Texas Lignite was substituted for Ohio No. 5 coal and Orinoco resid and Maya resid were used instead of Cold Lake resid. In summary, there was no significant effect observed on the overall process performance at selected operating conditions as a function of oil feedstock. An impact on product quality was observed, however. With both the Orinoco resid and the Maya resid, the product quality was poorer than when Cold Lake resid was used. There may have been some effect on catalyst deactivation rate for specific catalyst functionalities (such as denitrogenation and desulfurization). Coal conversion with the lignite was lower than with the bituminous coal; however, it was still in excess of $90 \mathrm{wt} \%$. There was no impact on $524 \mathrm{EC}^{+}$conversion by changing to the lignite from the bituminous coal. However, the low rank coal yielded a more aliphatic product with a lower sulfur content. ${ }^{34}$

Th effect of coal concentration was tested with the Texas lignite/Maya resid pair. It was shown that process performance improved with increasing coal concentration between 10 and 40 wt \% coal in the feed. ${ }^{38} 524 \mathrm{EC}^{+}$conversion increased from 80.5 wt \% with $10 \%$ coal to 90 wt \% with 40 wt \% coal in the feed. Other performance indicators (HDN, distillate yield, coal conversion) also showed improvement.

A significant difference in feedstock reactivity was noted when a test was made with Westerholt German bituminous coal and Cold Lake residuum. ${ }^{35}$ Coal conversion was $2 \mathrm{wt} \%$ lower and $524 \mathrm{EC}^{+}$conversion was $7 \mathrm{wt} \%$ lower than with Texas lignite/Maya resid. 
However, hydrogen efficiency and distillate selectivity were better with the Westerholt/Cold Lake pair.

Changes in processing conditions were examined with the Texas lignite/Maya system. A significant improvement in product quality was obtained when the two-stage system was operated with the first-stage reactor at a lower temperature than the second reactor. ${ }^{35}$ Alternative feedstock combinations were evaluated. Taiheiyo coal (a Japanese subbituminous coal) and Maya resid, Forrestburg (a Canadian subbituminous coal) and Cold Lake resid, Black Thunder (Wyoming, U.S. subbituminous coal) and Cold Lake resid, and New Mexico subbituminous coal and Hondo (California) vacuum still bottoms resid. ${ }^{37}$

Forrestburg coal was agglomerated with Cold Lake resid in order to reduce the ash content of the coal from $17.5 \mathrm{wt} \%$ to $11.7 \mathrm{wt} \%$, dry basis. The agglomerates contained $18.6 \mathrm{wt} \%$ oil. Coal conversion of the agglomerated coal was significantly lower than for the nonagglomerated case (91.3 vs. $93.9 \mathrm{wt} \%$ ). $524 \mathrm{EC}^{+}$conversion also was lower (83.1 vs $86.0 \mathrm{wt} \%$ ). A coal-drying step, preliminary to the agglomerating procedure, was postulated to be the reason for the lower conversions. ${ }^{37}$

Scale-up of the co-processing tests was initiated in 1989 when a test was made in the HRI $3 \mathrm{t} / \mathrm{d}$ PDU. Feedstocks for the test were Ohio No.5/6 coal and Cold Lake resid. The test was performed in three main segments: accelerated catalyst aging, demonstration, and alternative operating conditions. ${ }^{36}$ The accelerated catalyst aging in the firstsegment of the test provided a close approach (90\%) to equilibrium catalyst age for the second segment of the test. The performance for the demonstration segment is presented in Table 7-8 and compared with the bench-scale operation results and the design basis. Agreement between the results obtained in the PDU and bench unit agree well, and both agree well with the design basis. Two alternative operating conditions were evaluated in the last segment of the test to demonstrate the increased throughput of a prototype commercial plant. Both conditions were based on once-through operations, in which the recycle was replaced with fresh feed. The relative space velocity was increased to 1.5 , and the coal content of the feed was reduced from $50 \%$ to $40 \%$. The temperature was increased. Process performance decreased as a result of these changes. $524 \mathrm{EC}^{+}$conversion fell from $88 \mathrm{wt} \%$ 
to $80 \mathrm{wt} \% \mathrm{MAF}$ coal, and the sulfur content of the VGO increased from $0.26 \mathrm{wt} \%$ to $0.58 \mathrm{wt} \%$. Hydrogen consumption (4.4 to $3.3 \mathrm{wt} \%$ ) and gas yield (77 to $74 \mathrm{wt} \%$, gross) were reduced.

\section{Coal/Waste Plastics}

Coal and waste plastics were co-liquefied in a series of bench-scale tests ${ }^{39}$ and in the $3 \mathrm{t} / \mathrm{d}$ PDU. ${ }^{40}$ Both mixed plastics (combinations of high density and low-density polyethylenes, polypropylene, polyethylene terpthalate, and polystyrene) and high-density polyethylene (HDPE) alone were tested. The plastics were varied from 25 to $50 \mathrm{wt} \%$ of the feed. Illinois No. 6 coal and Black Thunder Mine coal were evaluated in these tests. The bench unit reactors were configured in the catalytic/thermal mode. Novel dispersed iron and molybdenum catalysts were evaluated.

Coal/plastics feeds were prepared in two ways. For the initial tests in the PDU, the plastics were slurried with recycle oil and fed to the slurry mix tank to which coal and more oil were added. A solvent to solids feed ratio of 2.25 was satisfactory for pumping the mixture. Some problems (foaming and bubbles) were encountered because of the high moisture content of the Wyoming subbituminous coal. A second method of feeding the plastics to the liquefaction unit was to make a slurry of coal and solvent at room temperature, heat it to 200-250 EC, then add the co-mingled plastics to the slurry at the elevated temperature. The mixture, after 30-60 min, was fluid and lump-free. The hot slurry was pumpable at 33 and $50 \mathrm{wt} \%$ plastics.

Performance with the coal/plastics feeds was very similar to direct liquefaction of coal alone in terms of coal conversion and product yields. ${ }^{40}$ However, the co-liquefaction resulted in reduced hydrogen consumption, higher distillate yields (as much as 15\% more), and less gas $\left(\mathrm{C}_{1}-\mathrm{C}_{3}\right)$. The quality of the distillates obtained was good; products had low nitrogen and sulfur contents. HDPE was found to be the most difficult feedstock to convert to liquid products at all scales (microautoclave, bench scale, and PDU). ${ }^{40}$

HTI developed the CoPro Plus ${ }^{T M}$ process (Figure 7-5) to co-liquefy organic wastes with coal and/or oil. ${ }^{41,42}$ As tested at the $3 \mathrm{lb} / \mathrm{h}$ scale, the process configuration is made up of a 
two-stage hydroconversion reactor, an interstage high pressure separator, and an in-line fixed-bed hydrotreater. Processing conditions were $425 \mathrm{EC}$ at $15 \mathrm{MPa}$; HTI's proprietary dispersed catalyst (GelCat ${ }^{\mathrm{TM}}$ ) was used. Table 7-9 presents the yields and performance comparison for tests made with oil, coal/oil, coal/oil/plastics, and oil/plastics.

\section{ECONOMIC IMPACTS/DRIVERS}

An economic evaluation and conceptual commercial plant design were formulated for the CTSL process early in the program based on Illinois No. 6 bituminous coal. ${ }^{3,10}$ The objective of the study was to calculate the economic incentive for CTSL relative to the single-stage $\mathrm{H}$-Coal Process. An engineering design of CTSL was produced on a consistent and directly comparable basis with the $\mathrm{H}$-Coal Process. Yields from coal liquefaction were elementally balanced based on a common coal feed analysis. The conceptual design included four parallel reactor trains for both the $\mathrm{H}-\mathrm{Coal}$ and CTSL evaluations. Partial oxidation of plant bottoms, supplemented with coal/water slurry when needed, was used as a consistent source of plant hydrogen. The distillate liquid product from liquefaction was hydrotreated and the hydrotreated heavy naphtha was catalytically reformed. The prime products from the plant are gasoline and diesel fuel.

Results of the conceptual commercial plant design and economic study are provided in Table 7-10. Because of the increased coal conversion to distillate in the CTSL process (36\% higher than $\mathrm{H}$-coal), CTSL requires supplemental coal to produce sufficient hydrogen. No gas by-product is produced in CTSL, whereas $\mathrm{H}$-Coal produces a significant amount. The total plant investment for CTSL is $10 \%$ higher than for the $\mathrm{H}$-Coal process. However, the costs are $12 \%$ lower on a per-barrel-of-product basis.

Economic screening studies continued throughout the program. Economic improvements resulted as the quantity and quality of the product distillates improved. The impact of bottoms recycle on the process economics is evident in Table 7-10.

The conceptual plant design and economic study was expanded to include PRB subbituminous coal. ${ }^{15}$ The low cost of the subbituminous coal makes it attractive as a feed to liquefaction. However, the higher moisture and oxygen contents of the PRB coal, 
compared to the Illinois No. 6 coal, are detrimental for liquefaction. The coal must be dried prior to liquefaction, and the oxygen is removed primarily as water. This consumes hydrogen and reduces potential liquefaction yields. The design basis and assumptions that were used are the following. The yields from liquefaction are elementally balanced based on demonstrated performance in the bench unit (Run 227-27 (W-5)). The CTSL product yield is $61.5 \mathrm{wt} \%$ on MAF coal basis. Five parallel reactor trains and an oil-to-solids ratio in the coal feed slurry of 1.5:1 were used. Deashing is used to provide a solids-free recycle. Reactor effluent from the second stage is quenched with recycle hydrogen to reduce the potential for coking in the reactor effluent separator and in downstream equipment. The slurry mix tank is operated at $177 \mathrm{EC}$ (lower than in the Illinois No. 6 case by about $40 \mathrm{EC}$ ). A summary of the economic analysis based on PRB coal is presented in Table 7-11. It was generally concluded that the cost of catalytic two-stage liquefaction of Wyoming coal is roughly equivalent to cost with Illinois coal.

The economics also were calculated for a single-stage co-processing add-on to an existing refinery. It was assumed that resid was available from the refinery and that utilities and offsites also were available. In 1986 dollars, it was shown that the cost of the finished product would be about $\$ 23-24 / \mathrm{bbl} .{ }^{33}$ Table 7-10 summarizes the results of the economic screening using the results of the bench-scale tests and compares them with the $\mathrm{H}$-Coal and direct coal liquefaction economics. Some of the key points which make the co-processing economics attractive are a reduction in capital cost of the facilities, reduced capital cost for infrastructure modifications, high-quality, high-value product, reduced sensitivity to feedstock cost fluctuations through the ability to modify coal/oil ratios, and the ability to operate at high (>90\%) $524 \mathrm{EC}^{+}$conversions without the need for expensive solids separation technology due to low ash content of blended coal/oil feedstock.

A techno-economic analysis of the CoPro Plus process for a site-specific plant producing $10,000 \mathrm{bbl} / \mathrm{d}$ are provided in Table 7-12.

\section{References for Chapter 7}

1. Shindler, H.D. "Coal Liquefaction: A Research Needs Assessment Technical Background Final Report, Volume II", DOE/ER-0400, February 1989. 
2. Comolli, A. G.; MacArthur, J. B.; McLean, J. B. "HRI's Two Stage Catalytic Coal Liquefaction Program-A Status Report", Proceedings of the 1984 DOE/FE Direct Liquefaction Contractors' Conference, Sandia National Laboratories, Albuquerque, New Mexico, October 17-18, 1984.

3. McLean, J. B.; Comolli, A . G.; Duddy, J. E.; Smith, T. O. "The Catalytic Two- Stage Liquefaction Process", Proceedings of the Direct Liquefaction Contractors' Conference, U.S. DOE Pittsburgh Energy Technology Center, Pittsburgh, PA, November 19-21, 1985.

4. Comolli, A. G.; McLean, J. B. "The Low-Severity Catalytic Liquefaction of Illinois No. 6 and Wyodak Coal", Proceedings of the Second Annual Pittsburgh Coal Conference, Pittsburgh, PA, September 16-20, 1985.

5. McLean, J. B.; Comolli, Smith, T. O. "Performance of the Low Temperature First Stage of HRI's Catalytic Two- Stage Liquefaction Process", Preprints American Chemical Society, Division of Fuel Chemistry, 31 (4), Anaheim, CA, September 1986, 268.

6. Comolli, A. G.; Johanson, J. B.;McLean, J. B.; Smith, T. O. "Process Variable Studies and Residual Oil-Extinction Recycle in Catalytic Two-Stage Liquefaction", Proceedings of the Direct Liquefaction Contractors' Conference, U.S. DOE Pittsburgh Energy Technology Center, Monroeville, PA, October 21-22, 1986.

7. McLean, J. B.; Comolli, A. G.; Johanson, J. B.; Smith, T. O. "Catalyst Comparisons in Catalytic Two- Stage Liquefaction", Proceedings of the Direct Liquefaction Contractors' Conference, U.S. DOE Pittsburgh Energy Technology Center, Monroeville, PA, October 21-22, 1986.

8. Comolli, A. G.; Ganguli, P.; Harris, E.; MacArthur, J. B.; McLean, J. B.; Smith, T. O. "New Technology Concept for Two-Stage Liquefaction of Coal", DOE/PC/60017-T1, August 1985.

9. McLean, J. B.; Comolli, A. G.; MacArthur, J. B. "HRI's Catalytic Two- Stage Liquefaction Process Performance Comparison for Illinois No.6 and Wyodak Coals", Preprints American Chemical Society, Division of Petroleum Chemistry, 30 (3), Chicago, September 1985, 530.

10. Abrams, L. M.; Caruso, R.; Duddy, J. E.; MacArthur, J. B. "New Technology Concept for Two-Stage Liquefaction of Coal: Conceptual Commercial Plant Design and Economics", DOE/PC/60017-T2, December 1985.

11. Comolli, A. G.; Duddy, J. E.; Koziel, M. L.; MacArthur, J. B.; McLean, J. B.; Smith, T. O. "New Technology Concept for Two-Stage Liquefaction of Coal Final Summary Report for July 1, 1983-September 30, 1985", DOE/PC/60017-10, February 1986. 
12. McLean, J. B.; Comolli, A. G.; Johanson, J. B.; Smith, T. O. "Catalytic Two- Stage Liquefaction Process Demonstration Results for Illinois No. 6 Coal", Proceedings of the Direct Liquefaction Contractors' Conference, U.S. DOE Pittsburgh Energy Technology Center, Pittsburgh, PA, October 1987.

13. McLean, J. B.; Comolli, A. G.; Johanson, J. B.; Smith, T. O. "Process Options for Extinction Recycle Conversion of Heavy Oils in Catalytic Two Stage Liquefaction", Preprints American Chemical Society, Division of Fuel Chemistry, 33 (1), Toronto, Canada, June 1988, 364.

14. Comolli, A. G.; Johanson, J. B. "Evolution of the Catalytic Two-Stage Liquefaction (CTSL) Process", Proceedings of the Direct Liquefaction Contractors' Review Meeting, U.S. DOE Pittsburgh Energy Technology Center, Pittsburgh, PA, October 46, 1988, 266.

15. Comolli, A. G.; Duddy, J. E.; Johanson, J. B.; Smith, T. O."Low-Severity Ctalytic TwoStage Liquefaction Process Final Summary Report September 1, 1985-February 28, 1988", DOE-80002-9, September 1988.

16. Comolli, A. G.; Johanson, J. B.; Panvelker, S. "Catalytic Two- Stage Liquefaction (CTSL) Process Studies on Subbituminous Coal", Proceedings of the Direct Liquefaction Contractors' Conference, U.S. DOE Pittsburgh Energy Technology Center, Pittsburgh, PA, October 3, 1989.

17. Comolli, A. G.; Johanson, J. B.; Panvelker, S. "CTSL ${ }^{\mathrm{TM}}$ Process Studies", Proceedings of the Direct Liquefaction Contractors' Conference, U.S. DOE Pittsburgh Energy Technology Center, Pittsburgh, PA, September 24-26, 1990.

18. Comolli, A. G.; Johanson, J. B.; Panvelker, S.; Popper, G. A. "CTSL ${ }^{\mathrm{TM}}$ Catalytic TwoStage Liquefaction Coupled with Coal Cleaning" Preprints American Chemical Society, Division of Fuel Chemistry, 36 (1), Atlanta, GA, April 1991, 75.

19. Comolli, A. G.; Johanson, J. B.; Panvelker, S.; Stalzer, R. H. "Close-Coupled TwoStage Catalytic Liquefaction Continuous Bench-Scale and Support Studies", Proceedings of the Direct Liquefaction Contractors' Review Meeting, U.S. DOE Pittsburgh Energy Technology Center, Pittsburgh, PA, September 3-5, 1991.

20. Comolli, A. G.; Johanson, J. B.; Lee, L. K..; Karolkiewicz, W. F.; Stalzer, R. H. "PDU Scale-Up of the CTSL Processing of Subbituminous Coal", Proceedings of the Liquefaction Contractors' Review Conference, U.S. DOE Pittsburgh Energy Technology Center, Pittsburgh, PA, September 22-24, 1992.

21. Lee, L. K.; Comolli, A. G.; Pradhan, V. R.; Stalzer, R. H. "Catalytic Multistage Liquefaction of Coal", Proceedings of the Coal and Gas Conversion Contractors' Review Conference, U.S. DOE Pittsburgh Energy Technology Center, Pittsburgh, PA, September 29, 1993. 
22. Comolli, A. G.; Lee, L. K..; Pradhan, V. R.; Stalzer, R. H. "Proof of Concept Facility for Direct Liquefaction", Proceedings of the coal and gas Conversion Contractors' Review Conference, U.S. DOE Pittsburgh Energy Technology Center, Pittsburgh, PA, October 7, 1993.

23. Lee, L. K.; Comolli, A. G.; Pradhan, V. R.; Stalzer, R. H. "A Study of Dispersed IronBased Additives in Coal Liquefaction", Preprints American Chemical Society, Division of Fuel Chemistry, 38 (1), Denver, CO, March 1993, 107.

24. Cugini, A. V.; et al."A Highly Active Disposable Iron Catalyst for Coal Liquefaction", Proceedings of the 7th US-Korea Joint Workshop on Coal Utilization Technology, Pgh, Pa, August 26-29, 1990, P. 240-250.

25. Stalzer, R. H.; Comolli, A. G.; Lee, L. K.; Pradhan, V. R. "Catalytic Multistage Liquefaction of Black Thunder Mine Coal Using Both Supported and Slurry Catalysts", Preprints American Chemical Society, Division of Fuel Chemistry, 38 (3), Chicago, IL, August 1993, 1073.

26. Lee, L. K.; Pradhan, V. R.; Stalzer, R. H.; Comolli, A. G. "Two-Stage Liquefaction of Wyoming Subbituminous Coal-Effect of Syngas as Reducing Gas", Preprints American Chemical Society, Division of Fuel Chemistry, 39 (4), ????? 1994, 1196.

27. Lee, L. K.; Pradhan, V. R.; Stalzer, R. H.; Johanson, E. S.; Comolli, A. G. "Catalytic Multi-Stage Liquefaction of Coal", Proceedings of the Coal and Gas Conversion Contractors' Review Conference, U.S. DOE Pittsburgh Energy Technology Center, Pittsburgh, PA, September 7, 1994.

28. Lee, L. K.; Pradhan, V. R.; Popper, G.; Comolli, A. G. " Dispersed Slurry Catalyts for Hydroconversion of Carbonaceous Materials", Preprints American Chemical Society, Division of Fuel Chemistry, 41 (3), August 25-29, 1996, 946.

29. Comolli, A. G.; Lee, L. K.; Pradhan, V. R.; Stalzer, R. H. "The Direct Liquefaction Proof of Concept Program", Preprints American Chemical Society, Division of Fuel Chemistry, 39 (4), August 20-25, 1994, 1187.

30. Comolli, A. G.; Lee, L. K.; Pradhan, V. R.; Stalzer, R. H. "The Direct Liquefaction Proof of Concept Programs POC-1 and POC-2", Proceedings of the Coal Liquefaction and Gas Conversion Contractors' Review Conference, U.S. DOE Pittsburgh Energy Technology Center, Pittsburgh, PA, September 7, 1994, 19.

31. Comolli, A. G.; Lee, L. K.; Pradhan, V. R.; Stalzer, R. H. "The Direct Liquefaction Proof of Concept Program", Proceedings of the Coal Liquefaction and Gas Conversion Contractors' Review Conference, U.S. DOE Pittsburgh Energy Technology Center, Pittsburgh, PA, August 29-31, 1995, 25. 
32. MacArthur, J. B. "HRI Coal/Oil Co-Processing Program-A Status Report", Proceedings of the Direct Coal Liquefaction Contractors' Conference, U.S. DOE Pittsburgh Energy Technology Center, Pittsburgh, PA, November 19-21, 1985, V-83.

33. Duddy, J. E.; MacArthur, J. B.; McLean, J. B. "HRI Coal/Oil Co-Processing Program", Proceedings of the Direct Coal Liquefaction Contractors' Conference, U.S. DOE Pittsburgh Energy Technology Center, Pittsburgh, PA, October 21-22, 1986, 304.

34. Duddy, J. E.; Harris, E.C.; Smith, T. O. " Coal/Oil Co-Processing Program-Status Report", Proceedings of the Direct Liquefaction Contractors' Review Conference, U.S. DOE Pittsburgh Energy Technology Center, Pittsburgh, PA, October 1987, 448.

35. Duddy, J. E. "HRI's DOE/Multi-Client Co-Processing Research Program", Proceedings of the Direct Liquefaction Contractors' Review Conference, U.S. DOE Pittsburgh Energy Technology Center, Pittsburgh, PA, October 1988, 60.

36. Duddy, J. E.; MacArthur, J. B.; Gustas, S.; Lawrence, J. "Coal/Oil Co-Processing Commercialization Reaches New Milestone", Proceedings Sixth Annual International Pittsburgh Coal Conference, Pittsburgh, PA September 1989.

37. Duddy, J. E.; Panvelker, S. V. "Bench-Scale Development of Coal/Oil Co-Processing Technology", Proceedings of the Direct Liquefaction Contractors' Review Conference, U.S. DOE Pittsburgh Energy Technology Center, Pittsburgh, PA, October, 1989, 75.

38. Duddy, J. E.; Panvelker, S.V. "Bench-Scale Development of Coal/Oil Co-Processing Technology: Effect of Coal Concentration on Reactivity", Proceedings of the Direct Liquefaction Contractors' Review Conference, U.S. DOE Pittsburgh Energy Technology Center, Pittsburgh, PA, September, 1991, 627.

39. Pradhan, V. R .; Lee, L. K.; Stalzer, R. H.; Johanson, E. S.; Comolli, A. G. "Catalytic Multi-Stage Liquefaction of Col at HTI; Bench-Scale Studies in Coal/Waste Plastics Coprocessing", Proceedings of the Coal Liquefaction and Gas Conversion Contractors' Review Conference, U.S. DOE Pittsburgh Energy Technology Center, Pittsburgh, PA, August 29-31, 1995, 75.

40. Pradhan, V. R.; Comolli, A. G.; Lee, L. K.; Stalzer, R. H. "Studies in Coal/Waste Coprocessing at Hydrocarbon Research, Inc.", Preprints American Chemical Society, Division of Fuel Chemistry, 40 (1), April 2-7, 1995, 82.

41. Comolli, A. G.; Lee, L. K.; Pradhan, V. "Alternate Fuels from the Co-Liquefaction of Coal, Oil, and Waste Plastics", Preprints American Chemical Society, Division of Fuel Chemistry, 40 (1), April 13-17, 1997, 736.

42. Comolli, A. G.; Ganguli, P.; Stalzer, R. H.; Lee, L. K.; Zhou, P.-Z.. "The Direct Liquefaction of Co-Processing Coal, Oil, Plastics, MSW, and Biomass", Preprints 
American Chemical Society, Division of Fuel Chemistry, 44 (2), March 21-25, 1999, 300. 
TABLE 7-1

COMPARISON OF H-COAL, DIRECT-COUPLED TWO-STAGE LIQUEFACTION, AND CATALYTIC TWO-STAGE LIQUEFACTION PROCESS FEATURES ${ }^{4}$

\begin{tabular}{|c|c|c|c|}
\hline Process & $\mathrm{H}$-Coal & DC-TSL (a) & CTSL (b) \\
\hline Reactor Stages & one & two & two \\
\hline First Stage Type & - & thermal & catalytic \\
\hline First Stage Temperature & - & high & low \\
\hline Second Stage Type & catalytic & catalytic & catalytic \\
\hline Second Stage Temperature & high & low & high \\
\hline Relative Overall Reactor Volume & 1.0 & 2.0 & 2.0 \\
\hline Severity, STTU (c) & 38 & 46 & 22 \\
\hline \multicolumn{4}{|l|}{ Thermal Coal Conversion } \\
\hline Stage 1 & - & fast & slow \\
\hline Stage 2 & fast & none & fast \\
\hline \multicolumn{4}{|l|}{ Catalytic Solvent Regeneration } \\
\hline Stage 1 & - & poor & excellent \\
\hline Stage 2 & fair & excellent & good \\
\hline \multicolumn{4}{|l|}{ Solvent Quality } \\
\hline Initial & fair & excellent & excellent \\
\hline Final & fair & poor & excellent \\
\hline $\begin{array}{l}\text { Catalytic Liquefaction Product } \\
\text { Stabilization }\end{array}$ & good & poor & excellent \\
\hline \multicolumn{4}{|l|}{ Overall } \\
\hline Distillate yield & fair & good & \\
\hline Residuum Conversion & fair & good & \\
\hline Liquid Selectivity & fair & good-excellent & good-excellen \\
\hline Product Quality & fair & good & good-excellen \\
\hline Catalyst Deactivation & high & low & moderate \\
\hline
\end{tabular}

a) DC-TSL = direct coupled two-stage liquefaction

b) $\mathrm{CTSL}=$ catalytic two-stage liquefaction

c) Standard Temperature Time Units $(\mathrm{STTU})=\mathrm{t}(\mathrm{min}) 10^{-6} \$ \mathrm{e}^{(-45045 / \mathrm{T} \mathrm{ER}+48.7)}$ 
TABLE 7-2

\section{COMPARISON OF HRI COAL LIQUEFACTION PROCESS RESULTS WITH SUBBITUMINOUS COAL ${ }^{3}$}

\begin{tabular}{|l|r|r|r|}
\hline Process & H-Coal & DC-TSL $^{\mathrm{a}}$ & CTSL $^{\mathrm{b}}$ \\
\hline Run No. & PDU-10-35 & $227-6-9$ & $227-27-21$ \\
\hline Yields,\% MAF Coal & & & \\
\hline $\mathrm{C}_{1}-\mathrm{C}_{4}$ & 11.0 & 9.6 & 8.3 \\
\hline $\mathrm{C}_{4}-199^{\circ} \mathrm{C}$ & 17.3 & 19.8 & 18.9 \\
\hline $199-343^{\circ} \mathrm{C}$ & 20.0 & 24.3 & 33.1 \\
\hline $343-524^{\circ} \mathrm{C}$ & 10.4 & 13.2 & 11.7 \\
\hline $524^{\circ} \mathrm{C}+$ residuum & 14.1 & 12.1 & 4.8 \\
\hline Hydrogen Consumption & 6.1 & 6.4 & 6.9 \\
\hline & & & \\
\hline Coal Conversion, wt \% MAF & 90.8 & 90.0 & 90.1 \\
\hline 524 EC ${ }^{+}$Conversion, wt \% MAF & 75.5 & 80.0 & 85.4 \\
\hline $\mathrm{C}_{4}-524$ EC, wt \% MAF & 47.7 & 57.3 & 63.7 \\
\hline Hydrogen Efficiency & & & \\
\hline
\end{tabular}

a) DC-TSL = direct coupled-two-stage liquefaction

b) $C T S L=$ catalytic two-stage liquefaction

c) Hydrogen Efficiency = t\% C4-975 EF Distillate wt \% Hydrogen Consumed 


\section{TABLE 7-3}

\section{COMPARISON OF YIELD DATA FROM RUNS MADE WITH FOUR DIFFERENT CATALYSTS ${ }^{7}$}

Run Conditions: First Stage Temperature $399^{\circ} \mathrm{C}$; Second Stage Temperature $427^{\circ} \mathrm{C}$; Hydrogen Pressure 2500 psig; Solvent/Coal $1.6 \mathrm{wt} / \mathrm{wt}$

\begin{tabular}{|l|l|l|l|l|}
\hline Run & I-13 & I-16 & I-17 & I-18 \\
\hline Catalyst & $\begin{array}{l}\text { American } \\
\text { Cyanamid } \\
\text { Amocat 1C }\end{array}$ & $\begin{array}{l}\text { Davison } \\
\text { Amocat 1C }\end{array}$ & $\begin{array}{l}\text { UOP } \\
\text { RCM -4 }\end{array}$ & $\begin{array}{l}\text { Shell } \\
\text { S-317 }\end{array}$ \\
\hline Diameter, in & $1 / 16$ & $1 / 32$ & $\sim 1 / 20$ & $1 / 32$ \\
\hline Yields, wt \% MAF & & & & \\
\hline $\mathrm{C}_{1}-\mathrm{C}_{3}$ & 6.1 & 5.6 & 5.9 & 5.8 \\
\hline $\mathrm{C}_{4}-199 \mathrm{EC}$ & 19.2 & 16.8 & 17.3 & 17.0 \\
\hline $199-343$ EC & 33.7 & 33.6 & 32.1 & 31.4 \\
\hline 343-524 EC & 16.7 & 20.0 & 20.5 & 20.4 \\
\hline 524 EC+ resid & 9.0 & 8.4 & 8.8 & 9.4 \\
\hline & & & & 68.8 \\
\hline $\mathrm{C}_{4}-524$ EC & 69.5 & 70.4 & 70.0 & 84.4 \\
\hline 524 EC Conversion & 85.4 & 85.0 & 84.9 & 93.7 \\
\hline Coal Conversion & 94.4 & 93.4 & 93.7 & 7.0 \\
\hline $\mathrm{H}_{2}$ Conversion & 6.9 & 7.2 & 7.0 & \\
\hline
\end{tabular}


TABLE 7-4

COMPARISON OF CLEANED ILLINOIS NO. 6 COAL FEED SAMPLES ${ }^{12}$

\begin{tabular}{|l|r|r|}
\hline Sample & Mine-Washed & Heavy Media Cleaned \\
\hline Proximate Analysis, wt \% dry & & \\
\hline Fixed Carbon & 51.5 & 54.1 \\
\hline Volatile Matter & 40.4 & 40.4 \\
\hline Ash & 10.3 & 5.5 \\
\hline Ultimate Analysis, wt \% dry & & 73.9 \\
\hline Carbon & 70.4 & 4.9 \\
\hline Hydrogen & 4.5 & 1.5 \\
\hline Nitrogen & 1.4 & 2.8 \\
\hline Sulfur & 3.6 & 5.8 \\
\hline Ash & 10.6 & 12.1 \\
\hline Oxygen (by difference) & 9.5 & \\
\hline Petrographic Analysis, v\% & & 91.5 \\
\hline Total Reactives & 88.2 & 8.5 \\
\hline Total Inerts & 11.8 & 0.3 \\
\hline Fusinite & 1.9 & \\
\hline
\end{tabular}


TABLE 7-5

EXPERIMENTAL RESULTS OF BOTTOMS AND VACUUM GAS OIL EXTINCTION CTSL BENCH UNIT OPERATIONS WITH OHIO COAL ${ }^{14}$

\begin{tabular}{|c|c|c|}
\hline Mode & Bottoms Extinction & Vacuum Gas Oil Extinction \\
\hline Run & $0-2$ & $0-2$ \\
\hline Days on Stream, avg. & 7 & 18 \\
\hline First-stage temperature, EC & 400 & 407 \\
\hline Second-stage temperature, $\mathrm{EC}$ & 430 & 437 \\
\hline $\begin{array}{l}\text { End Point, Atmospheric } \\
\text { Overhead Product, EC }\end{array}$ & 372 & 369 \\
\hline End point, Vacuum Gas Oil, EC & & 524 \\
\hline \multicolumn{3}{|l|}{$\begin{array}{l}\text { Product Distribution, wt \% MAF } \\
\text { Coal }\end{array}$} \\
\hline $\mathrm{C}_{1}-\mathrm{C}_{3}$ & 7.9 & 10.1 \\
\hline $\mathrm{C}_{4}-199$ EC Naphtha & 19.1 & 18.8 \\
\hline 199-343 EC Distillate & 36.8 & 38.1 \\
\hline 343-524 EC Distillate & 14.6 & 8.1 \\
\hline $\mathrm{C}_{4}$-399 EC Distillate & 70.5 & 65.1 \\
\hline 399-524 EC Gas Oil & 8.5 & 0.3 \\
\hline $524 \mathrm{EC}^{+}$Residual Oil & 1.8 & 14.1 \\
\hline Unconverted Coal & 5.2 & 4.8 \\
\hline Water & 10.0 & 9.0 \\
\hline $\mathrm{H}_{2} \mathrm{~S}, \mathrm{NH}_{3}, \mathrm{COx}$ & 3.5 & 3.4 \\
\hline Total $\left(100=\mathrm{H}_{2}\right.$ Reacted $)$ & 107.4 & 106.7 \\
\hline $\mathrm{C}_{4}-399$ EC Distillate Yield, bbl/t & 4.3 & 4.0 \\
\hline
\end{tabular}


TABLE 7-6

OPERATING CONDITIONS AND PERFORMANCE SUMMARY FOR TEMPERATURE SEQUENCE TEST (RUN 227-55) WITH BLACK THUNDER MINE SUBBITUMINOUS COAL ${ }^{16}$

\begin{tabular}{|l|r|r|r|r|r|r|}
\hline Condition & 1 & 2 & 3 & 4 & 5 & 6 \\
\hline Days & 6 & 3 & 3 & 3 & 3 & 3 \\
\hline Nominal Conditions & & & & & & \\
\hline Coal Feed, Ib/h,ft ${ }^{3}$ (catalyst) & 44 & 44 & 44 & 44 & 44 & 67 \\
\hline Solvent Recycle, Ib/lb Coal & & & & & & \\
\hline Filtered Liquid & 1.01 & 0.71 & 0.71 & 0.71 & 0.71 & 0.71 \\
\hline Topped Separator Bottoms & 0.00 & 0.38 & 0.38 & 0.38 & 0.38 & 0.38 \\
\hline Reactor Temperature, EC & & & & & & \\
\hline First Stage & 399 & 399 & 424 & 436 & 399 & 399 \\
\hline Second Stage & 427 & 441 & 424 & 408 & 441 & 441 \\
\hline & & & & & & \\
\hline Performance Summary, & & & & & & \\
wt \% MAF Coal & & & & & & \\
\hline C $_{4}-524$ & 63.8 & 67.9 & 64.8 & 62.3 & 63.6 & 59.8 \\
\hline 524 EC+ & 84.6 & 88.6 & 87.5 & 89.1 & 87.4 & 82.7 \\
\hline Coal Conversion & 87.2 & 91.4 & 91.4 & 92.3 & 91.8 & 87.3 \\
\hline Hydrodesulfurization & 70.0 & 71.0 & 71.0 & 72.0 & 71.0 & 69.0 \\
\hline Hydrodenitrogenation & 72.0 & 75.0 & 75.0 & 80.0 & 76.0 & 65.0 \\
\hline Hydrogen Consumption & 8.0 & 8.2 & 8.2 & 8.5 & 8.0 & 7.1 \\
\hline
\end{tabular}


TABLE 7-7

TESTS OF WATER-GAS-SHIFT CATALYSIS

\begin{tabular}{|c|c|c|c|c|}
\hline Run & CMSL-03 & CMSL-03 & CMSL-04 & CMSL-04 \\
\hline Process Conditions & 1 & 2 & 1 & 2 \\
\hline \multicolumn{5}{|l|}{ First Stage } \\
\hline $\mathrm{CO} / \mathrm{H}_{2}$ & $0 / 100$ & $75 / 25$ & $0 / 100$ & $0 / 100$ \\
\hline Temperature, EC & 388 & 388 & 388 & 427 \\
\hline Catalyst & AHM & $\mathrm{AHM}$ & Shell 317 & Shell 317 \\
\hline \multicolumn{5}{|l|}{ Second Stage } \\
\hline $\mathrm{CO} / \mathrm{H}_{2}$ & $0 / 100$ & $0 / 100$ & $0 / 100$ & $0 / 100$ \\
\hline Temperature, EC & 427 & 427 & 427 & 427 \\
\hline Catalyst & Shell 317 & Shell 317 & Shell 317 & Shell 317 \\
\hline \multicolumn{5}{|c|}{ Process Performance, wt \% MAF Coal } \\
\hline Coal Conversion & 89.5 & 92.0 & 86.8 & 87.6 \\
\hline $514 \mathrm{EC}+$ Conversion & 87.5 & 89.9 & 84.6 & 84.5 \\
\hline $\mathrm{C}_{1}-\mathrm{C}_{3}$ & 6.50 & 6.56 & 6.30 & 7.65 \\
\hline $\mathrm{C}_{4}-524 \mathrm{EC}$ & 61.6 & 64.6 & 57.6 & 58.8 \\
\hline $\mathrm{H}_{2}$ Used & 7.82 & 7.73 & 8.10 & 9.61 \\
\hline HDN & 75.9 & 84.8 & 96.9 & 95.1 \\
\hline
\end{tabular}


TABLE 7-8

COMPARISON OF PDU CO-PROCESSING DEMONSTRATION, BENCH-SCALE TEST, AND DESIGN BASIS ${ }^{36}$

\begin{tabular}{|c|c|c|c|}
\hline & PDU Demonstration & Bench-Scale Test & Design Basis \\
\hline Days & $23-38$ & 25 & - \\
\hline $\begin{array}{l}\text { Percent of Equilibrium Catalyst } \\
\text { Age }\end{array}$ & 89 & 87 & 100 \\
\hline \multicolumn{4}{|l|}{$\begin{array}{l}\text { Process Performance, wt } \% \\
\text { MAF Coal }\end{array}$} \\
\hline $524 \mathrm{EC}^{+}$Conversion & 88 & 88 & 87 \\
\hline Coal Conversion & 95 & 95 & 95 \\
\hline HDS & 83 & 78 & 76 \\
\hline HDN & 78 & 73 & 77 \\
\hline \multicolumn{4}{|l|}{ Product Yield, wt \% Dry Feed } \\
\hline $\mathrm{C}_{1}-\mathrm{C}_{3}$ & 7 & 8 & 8 \\
\hline $\mathrm{C}_{4^{-}} 524 \mathrm{EC}^{+}$(gross) & 77 & 74 & 73 \\
\hline $\mathrm{C}_{4^{-}} 524 \mathrm{EC}^{+}(\mathrm{net})$ & 71 & 69 & 68 \\
\hline $\begin{array}{l}\text { Hydrogen Consumption, wt \% } \\
\text { Dry Feed }\end{array}$ & 4.4 & 4.5 & 4.6 \\
\hline \multicolumn{4}{|l|}{$\begin{array}{l}\text { VGO (343-524 EC) Product } \\
\text { Quality, wt } \%\end{array}$} \\
\hline Hydrogen & 10.9 & 10.7 & 10.5 \\
\hline Sulfur & 0.26 & 0.37 & 0.42 \\
\hline Nitrogen & 0.30 & 0.25 & 0.27 \\
\hline
\end{tabular}


TABLE 7-9

PERFORMANCE COMPARISON FOR CO-PROCESSING IN THE HTI COPRO PLUS PROCESS ${ }^{41}$

\begin{tabular}{|c|c|c|c|c|}
\hline Feed & Oil & Coal/Oil & Coal/Oil/Plastics & Oil/Plastics \\
\hline Coal & 0 & 50 & 33.3 & 0 \\
\hline Plastic & 0 & 0 & 33.3 & 50 \\
\hline Oil & 100 & 50 & 33.3 & 50 \\
\hline \multicolumn{5}{|l|}{ Relative Severity Index (a) } \\
\hline First Stage & 0.78 & 0.98 & 1.08 & 0.90 \\
\hline Second Stage & 1.07 & 1.28 & 1.47 & 1.19 \\
\hline $\begin{array}{l}\text { Process Performancer, wt \% } \\
\text { MAF feed }\end{array}$ & & & & 99.7 \\
\hline Feed Conversion & 99.9 & 96.1 & 96.7 & 99.7 \\
\hline $\mathrm{C}_{4}-524$ EC Distillate Yield & 76.0 & 69.7 & 73.9 & 76.2 \\
\hline $524{ }^{\circ} \mathrm{C}^{+}$Conversion & 83.3 & 82.7 & 83.7 & 84.0 \\
\hline Hydrogen Consumption & 1.72 & 4.21 & 3.17 & 1.35 \\
\hline $\mathrm{C}_{1}-\mathrm{C}_{3}$ Gas Yield & 5.00 & 7.37 & 5.31 & 4.31 \\
\hline \multicolumn{5}{|l|}{ SOH Distillate, wt \% } \\
\hline IBP-177 EC & 39.6 & 42.1 & 52.4 & 53.4 \\
\hline 177-343 EC & 52.1 & 50.9 & 40.7 & 41.7 \\
\hline $343 \mathrm{EC}^{+}$ & 8.3 & 7.0 & 6.9 & 4.9 \\
\hline \multicolumn{5}{|l|}{ SOH Quality } \\
\hline Gravity, API & 49.0 & 46.1 & 46.3 & 51.0 \\
\hline H/C Ratio & 1.99 & 1.96 & 1.90 & 1.97 \\
\hline Nitrogen, ppm & 32.2 & 15.5 & 17.9 & 5.4 \\
\hline Sulfur, ppm & 96.9 & 52.7 & 46.2 & 17.5 \\
\hline$\%$ Aromaticity & 7.25 & 17.82 & 23.49 & 14.89 \\
\hline
\end{tabular}

a) The relative sensitivity index is based on a standard sensitivity index of 1.0 at a space velocity of $800 \mathrm{~kg} / \mathrm{h} / \mathrm{m}^{3}$ each reactor and a temperature of $440^{\circ} \mathrm{C}$ 
TABLE 7-10

ECONOMIC COMPARISON OF H-COAL AND CTSL ${ }^{3,14}$

AND SINGLE-STAGE COAL/OIL CO-PROCESSING ${ }^{33}$

\begin{tabular}{|c|c|c|c|c|}
\hline Process & H-Coal & CTSL & $\begin{array}{l}\text { CTSL with } \\
\text { Bottoms } \\
\text { Recycle }\end{array}$ & $\begin{array}{l}\text { Coal/Oil Co- } \\
\text { Processing }\end{array}$ \\
\hline Coal Feed & $\begin{array}{c}\text { Illinois No. } 6 \\
\text { Bituminous } \\
\text { Coal }\end{array}$ & $\begin{array}{c}\text { Illinois No. } 6 \\
\text { Bituminous } \\
\text { Coal }\end{array}$ & $\begin{array}{c}\text { Illinois No. } 6 \\
\text { Bituminous } \\
\text { Coal }\end{array}$ & $\begin{array}{c}\text { Ohio Nos. } \\
5 \& 6 \\
\text { Bituminous } \\
\text { Coal }\end{array}$ \\
\hline \multicolumn{5}{|l|}{ Coal Feed, TPSD } \\
\hline To liquefaction & 9428 & 9428 & 8400 & 1500 \\
\hline To partial oxidation & 0 & 1552 & 4405 & \\
\hline Total & 9482 & 10980 & 12805 & 1500 \\
\hline Oil Feed, TPSD & - & - & - & 1500 \\
\hline Purchased Electric Power, MW & 82 & 90 & 106 & \\
\hline \multicolumn{5}{|l|}{ Liquid Products, BPSD } \\
\hline Gasoline & 9700 & 10967 & 13170 & 4035 \\
\hline Diesel & 16078 & 23967 & 28779 & 10174 \\
\hline Total & 25778 & 34934 & 41948 & 14209 \\
\hline \multicolumn{5}{|l|}{ By-Products } \\
\hline LPG, BPSD & 4144 & 0 & 289 & - \\
\hline Sulfur, TPSD & 323 & 376 & 329 & 97 \\
\hline Ammonia, TPSD & 107 & 112 & 143 & 22 \\
\hline Ash to disposal, TPSD & 1069 & 1254 & 1498 & 261 \\
\hline Total Plant investment, MM\$ (a) & 1738 & 1918 & 2109 & 261 \\
\hline \multicolumn{5}{|l|}{ Product Cost (b) } \\
\hline Operating Cost, $\mathrm{MM} \$ / \mathrm{y}$ & 429 & 479 & 546 & 118 \\
\hline By-Product Revenue, MM $\$ / \mathrm{y}$ & 38 & 12 & 15 & 5 \\
\hline Product Cost, MM\$/y & 391 & 467 & 531 & 113 \\
\hline Product Cost, $\$ / \mathrm{bbl}$ & 45.94 & 40.52 & 38.35 & 24.10 \\
\hline Percent Difference & base & $-12 \%$ & $-17 \%$ & $91 \%$ \\
\hline
\end{tabular}

a) 1984 total erected cost at a U.S. Gulf Coast location. Includes $25 \%$ project contingency.

b) First year product cost based on $25 \%$ equity, $15 \%$ DCF return, $10 \%$ interest on debt and $5.0 \%$ annual inflation. 
TABLE 7-11

SUMMARY OF PRB SUBBITUMINOUS COAL CTSL ECONOMICS ${ }^{15}$

\begin{tabular}{|l|r|}
\hline Coal Feed to Liquefaction, TPSD & 10000 \\
\hline Purchased Electric Power, MW & 108 \\
\hline Purchased Natural Gas, MMSCFD & 92 \\
\hline Liquid Products, BPSD & 12660 \\
\hline Gasoline & 24160 \\
\hline Diesel & 948 \\
\hline Turbine Fuel & 37768 \\
\hline TOTAL & 100 \\
\hline By-Products & 80 \\
\hline Sulfur, TPSD & 914 \\
\hline Ammonia, TPSD & 1887 \\
\hline Ash to Disposal, TPSD & \\
\hline Total Plant investment, \$MM (a) & 495 \\
\hline Product Cost (b) & \\
\hline Operating Cost, \$MM/y & 489 \\
\hline By-Product Revenue, \$MM/y & 39.30 \\
\hline Product Cost, \$MM/y & \\
\hline Product Cost, \$/bbl & \\
\hline
\end{tabular}
a) 1984 total erected cost at a U.S. Gulf Coast location. Includes $25 \%$ project contin- gency.

b) First year product cost based on $25 \%$ equity, 15\% DCF return, $10 \%$ interest on debt and $5.0 \%$ annual inflation. 
TABLE 7-12

ECONOMIC COMPARISON FOR HTI COPRO PLUS PROCESS ${ }^{41}$

\begin{tabular}{|c|l|l|l|l|}
\hline Feed (a) & Oil & Coal/Oil & Coal/Oil/Plastics & Oi//Plastics \\
\hline Feed Composition, wt \% & & & & \\
\hline Coal, t/d & 0 & 6000 & 4000 & 0 \\
\hline Oil, bbl/d & 66730 & 33365 & 22243 & 33365 \\
\hline Plastics, t/d & 0 & 0 & 4000 & 6000 \\
\hline Liquid Products, bbl/d & & & & \\
\hline Gasoline & 15148 & 14339 & 15192 & 15328 \\
\hline Diesel Fuel & 36787 & 34822 & 36896 & 37225 \\
\hline Total & 51935 & 49161 & 52088 & 52553 \\
\hline Total Plant Investment, \$MM(b) & 1945 & 2379 & 2078 & 1733 \\
\hline Net Operating Cost, \$MM/y & 566.8 & 561.4 & 486.1 & 449.7 \\
\hline Net Product Cost, \$/bbl & 33.22 & 34.76 & 28.41 & 26.05 \\
\hline $\begin{array}{l}\text { Equivalent Crude Oil Pice, } \\
\text { \$/bbl (c) }\end{array}$ & 27.19 & 28.70 & 22.63 & 20.48 \\
\hline
\end{tabular}

a) Total feed: $12,000 \mathrm{t} / \mathrm{d}$

b) U.S. Gulf Coast location; four-year construction period; 25 year operating life; capital cost depreciated over 10 years using straight-line depreciation; federal tax rate of $34 \%$ assumed; feed costs and selling price annually inflated $3 \%$.

c) Based on published crude oil price data and product prices. Ratios of crude:specific products were determined. Equivalent Crude Oil Price calculated from the ratio multiplied times the product cost. This value is the required crude oil selling price so that the proposed facility would have a $15 \%$ rate of return on invested equity. 


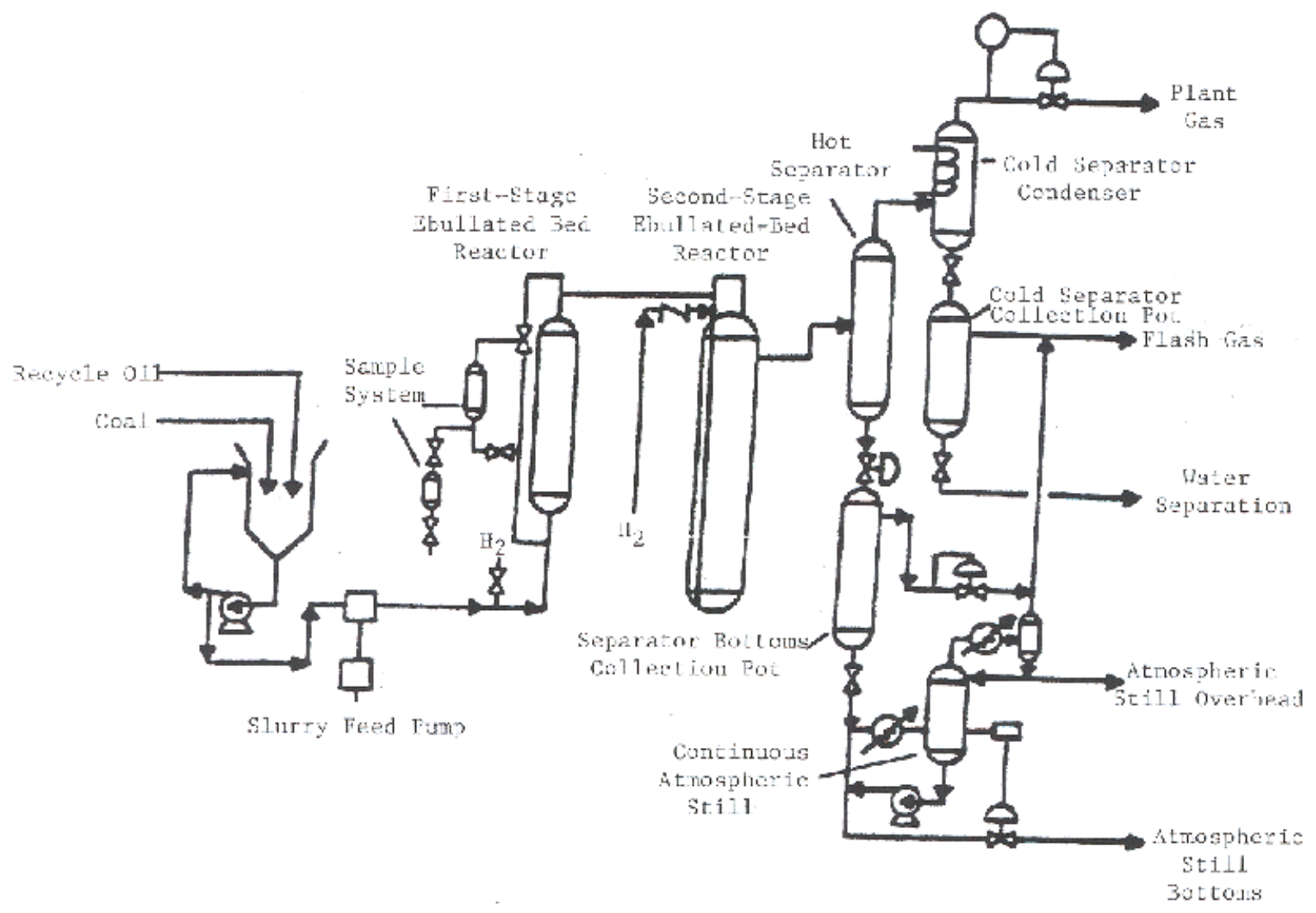

Figure 7-1. HRI Catalytic Two-Stage Unit (Reference 1). 


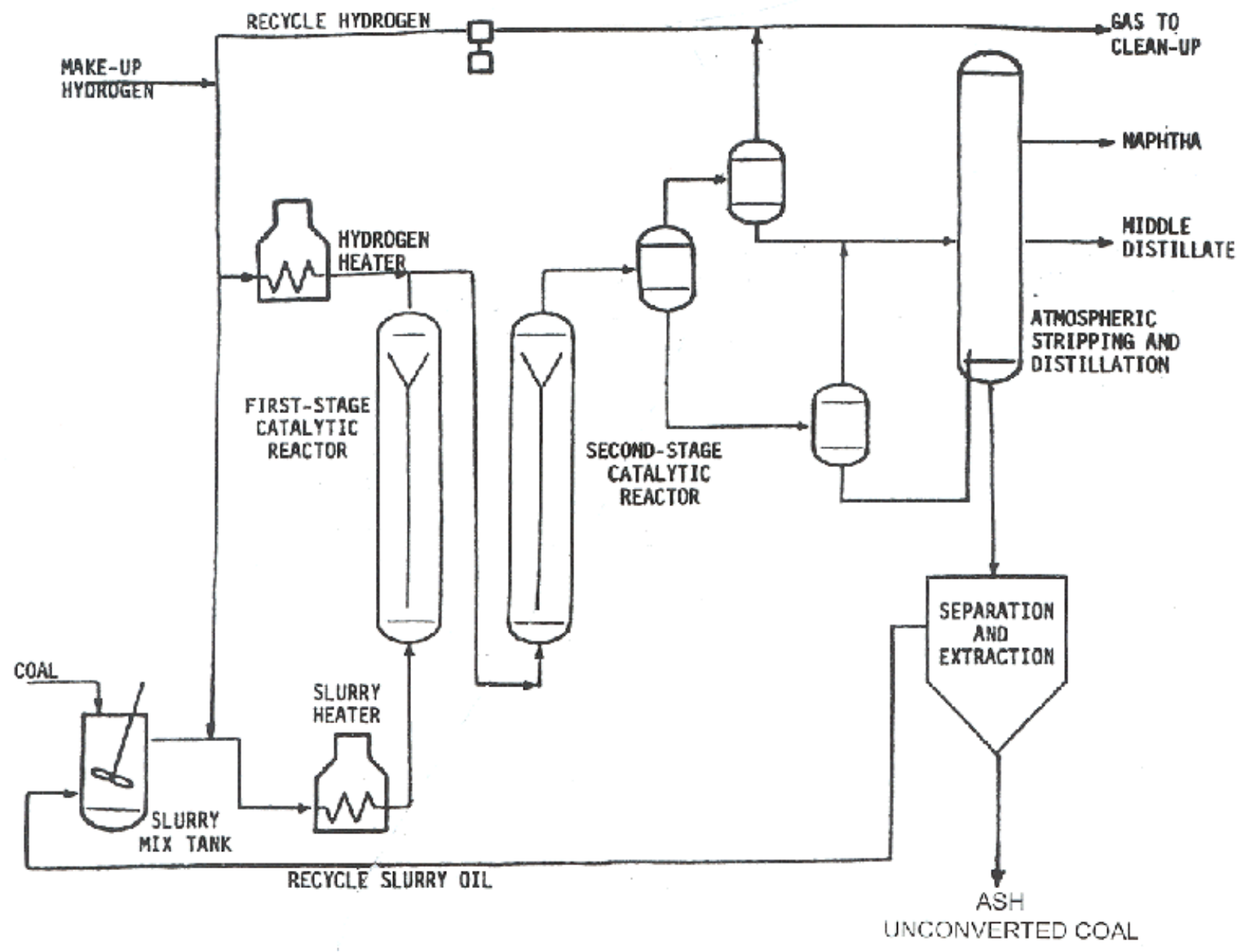

Figure 7-2. Catalytic Two-Stage Liquefaction (Simplified Process Flow Diagram), Extinction Recycle. ${ }^{6}$ 


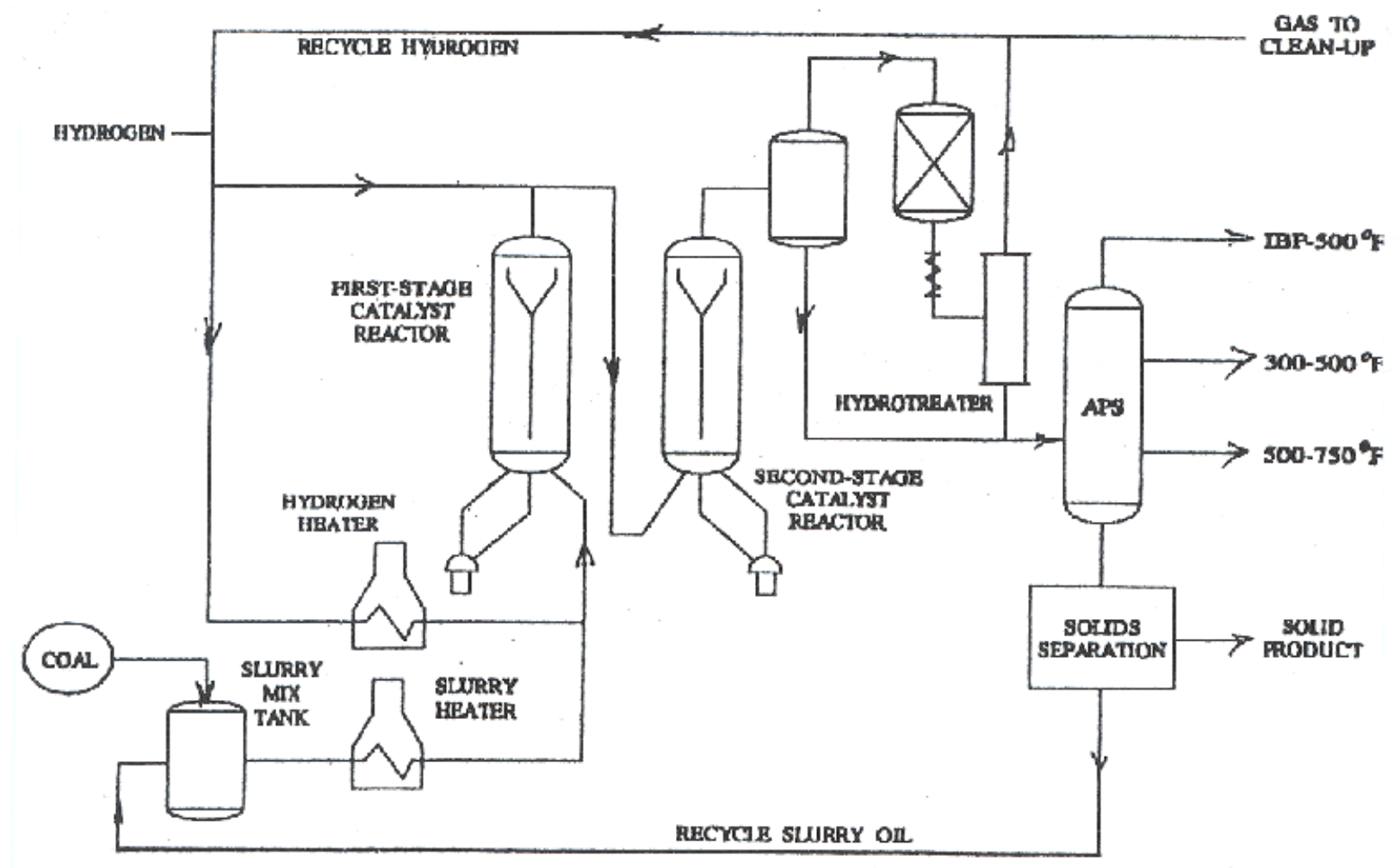

Figure 7-3. POC Facility at Hydrocarbon Research, Inc.

(Simplified Flow Plan). 


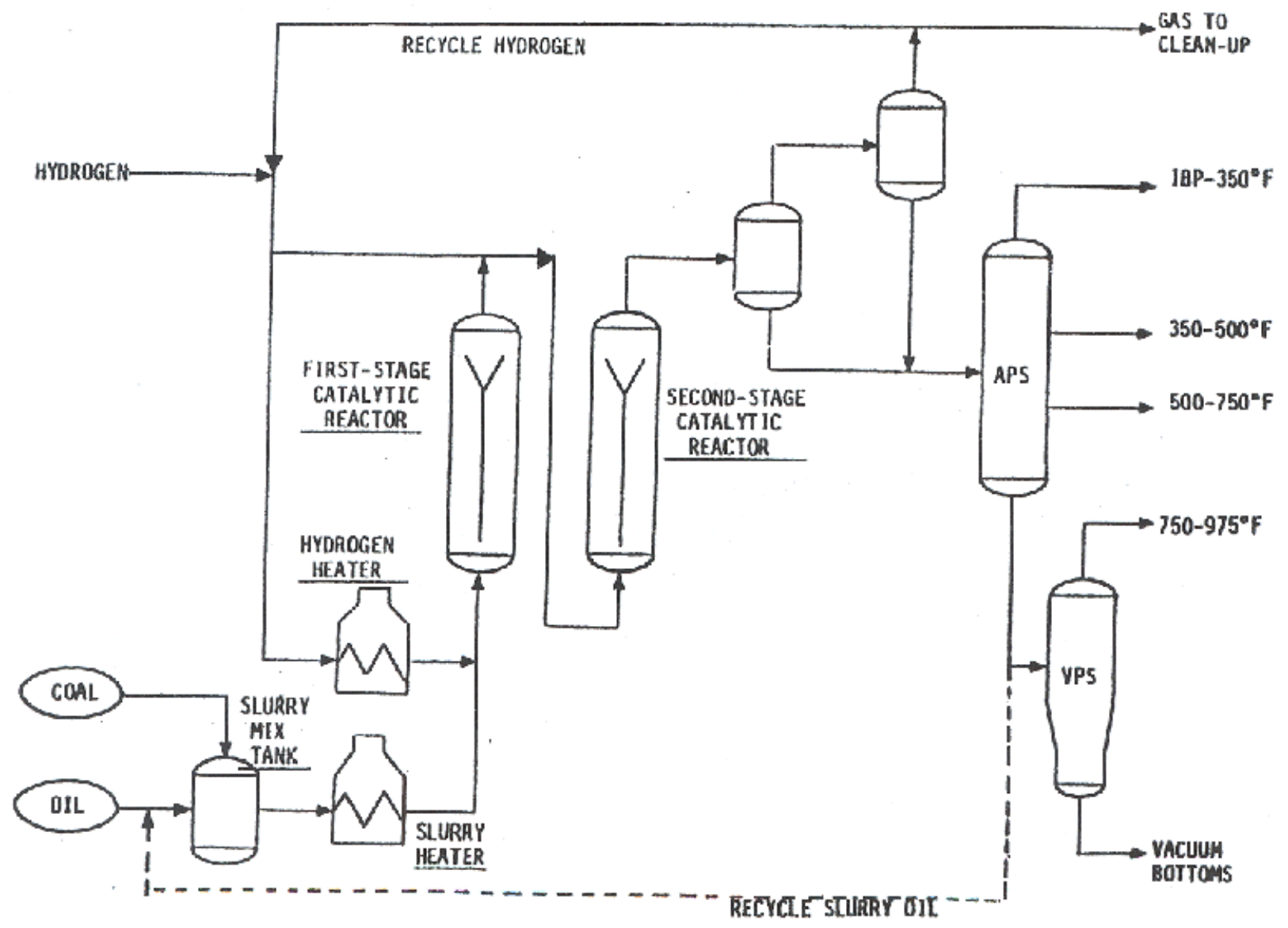

Figure 7-4. HRI's Catalytic Two-Stage Coal/Oil Co-Processing (Simplified Flow Plan). ${ }^{33}$ 


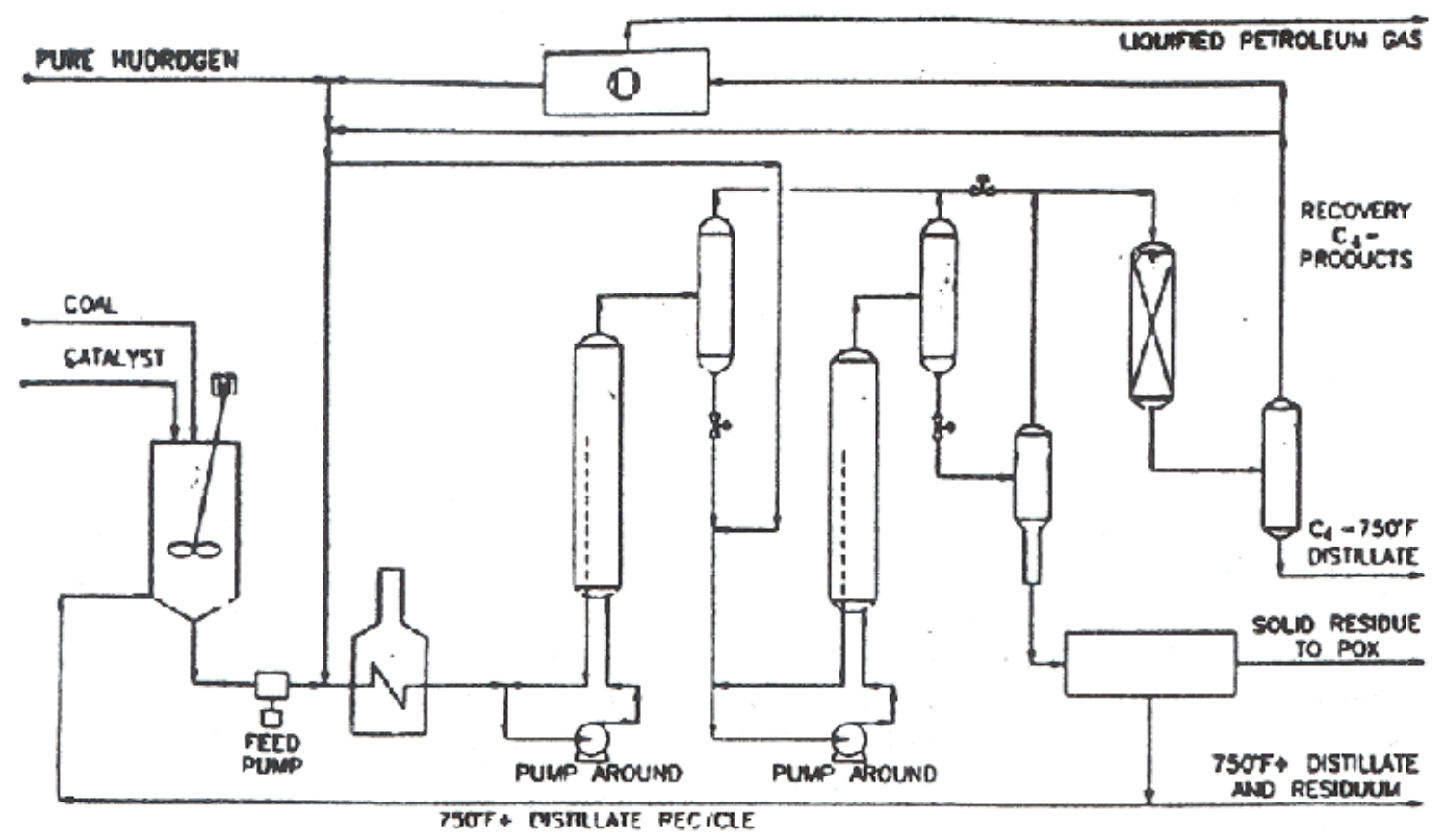

Figure 7-5. HRI's CoPro Plus ${ }^{\mathrm{TM}}$ Process (Simplified Schematic). 


\title{
Chapter 8
}

\section{SELECTED ACCOMPLISHMENTS OF CONSOL'S PROCESS DEVELOPMENT SUPPORT PROGRAM}

\author{
F. P. Burke, R. A. Winschel - CONSOL Energy Inc.
}

\section{INTRODUCTION}

The Research and Development Department of CONSOL Energy Inc., and its forerunner organizations, ${ }^{1}$ has been an active participant in the DOE direct liquefaction process development program since 1979. The principal contracts that formalized this participation are listed at the end of the bibliography for this chapter.

The two principal foci of this work have been 1) characterization of direct coal liquefaction process oils and associated analytical methods development and analytical methods applications, and 2) direct coal liquefaction process development. The following briefly describes some selected accomplishments of this work, organized according to the two foci. This chapter is followed by a bibliography of papers and presentations by CONSOL authors related to the work described. Supporting contracts are included at the end of the bibliography.

\section{CHARACTERIZATION ACCOMPLISHMENTS}

The materials produced by direct coal liquefaction are complex mixtures which span a significant range in composition. Describing the composition and character of a coal liquid requires the use of a variety of tools to separate, identify, and quantify the yields of products, individual components or component classes, and to measure other important parameters, such as elemental composition. This information can be used to make various statements about the liquefaction process which are useful in process development.

${ }^{1}$ Conoco Coal Development Co.; Conoco Inc., Coal Research Division; Consolidation Coal Co., Research Division; CONSOL Inc., Research \& Development Department 
There are various reasons for performing analyses of coal liquids. It is important to determine the compositions of liquid products relative to end use specifications. Their environmental impact must be assessed. Data on yields and physical properties must be obtained for engineering design.

Within the process itself, analytical data are used to follow the chemical transformation of coal to residual liquids, and of the residual liquids to distillate products. Since both distillate and residual liquids commonly are recycled in the process, their compositions have an impact on process performance in both roles of reactants and recycle solvent. The interactive nature of recycle solvent composition, process conditions, and process performance makes the characterization of the recycle stream particularly useful in assessing a variety of process performance factors.

\section{Microautoclave and ${ }^{1} \mathrm{H}-\mathrm{NMR}$ Solvent Quality Methods ${ }^{9}$}

Some 467 liquefaction process oils were analyzed by ${ }^{1} \mathrm{H}-\mathrm{NMR}$. Three parameters derived from the ${ }^{1} \mathrm{H}-\mathrm{NMR}$ analyses were compared, using multiple linear regressions, with the results of 577 microautoclave tests with those oils. In each case in which the parameter was significant, the aromatic and paraffinic parameters showed negative correlations with coal conversion (solvent quality) and the hydroaromatic parameter showed a positive correlation with coal conversion (solvent quality).

These regression results apply to authentic distillate liquefaction process oils and may not apply to model compounds, synthetic oils, or other oils produced by means other than coal liquefaction. The 467 oils used in the correlations had boiling point distributions varying within the range 473 to $808 \mathrm{~K}$. Therefore, the observed change in microautoclave coal conversions with boiling point is offset in the correlations by the concomitant change in proton distributions with boiling point. However, oils that contain substantial portions of nondistillable material will not necessarily fit the regressions. Although the qualitative effects of the correlating terms may be the same for resid containing solvents, the amount of residue in the solvent may be important. The ${ }^{1} \mathrm{H}$-NMR donor solvent quality assay is directly applicable to processes which use distillate-only solvents, such as the SRC-1 and the Exxon 
Donor Solvent processes (without bottoms recycle) and to the distillate portion (usually greater than $50 \%$ ) of residue-containing solvents such as those from the SRC-II, H-Coal and ITSL processes.

This work demonstrates that ${ }^{1} \mathrm{H}-\mathrm{NMR}$ and microautoclave tests give consistent measures of solvent quality for a wide rate of distillate solvents. The three different microautoclave tests measure different solvent properties, as they were designed to do. Microautoclave extractions are insensitive to solvent quality differences above some point, although ${ }^{1} \mathrm{H}-\mathrm{NMR}$ is sensitive to these differences. There are many advantages in using the ${ }^{1} \mathrm{H}-\mathrm{NMR}$ measurement. It provides reproducible fundamental information that can be used to interpret solvent quality in a chemical sense. It is useful for comparing solvents, for determining the effect of processing variables on solvent quality, and for determining the effects of solvent quality on process performance.

\section{Donor Hydrogen Depletion in Coal Liquefaction ${ }^{64}$}

A ${ }^{1} \mathrm{H}-\mathrm{NMR}$ method was developed that provides a measurement of the loss in donor hydrogen of a solvent during coal liquefaction. The method is fast and relatively simple to perform. It relies on several assumptions that limit the scope of its application. Nevertheless, within these limitations, the method is found to give comparable results to much more complex compositional analyses.

The donor hydrogen depletion (DHD) method is a rapid ${ }^{1} \mathrm{H}-\mathrm{NMR}$ method that provides a measurement of hydrogen transferred from or added to a coal liquefaction solvent. For use as a quantitative method, it is best suited to non-catalytic liquefaction and to solvent hydrotreating operations. However, for catalytic liquefaction, the method still provides relative differences between feed and product solvents. The DHD method was found to provide results comparable to $\mathrm{GC}$ and GC/MS compositional analyses on solvents as complex as hydrogenated phenanthrenes. Compositional analyses are extremely difficult to perform on authentic liquefaction oils, whereas the DHD method is simple. 
In batch donor liquefaction experiments, coal conversion to THF solubles was found to increase with increasing donor hydrogen depletion, except at high severity conditions where retrogressive reactions become significant. In continuous hydroliquefaction tests, the yield of 206 x $535 \mathrm{EC}$ distillate correlated inversely with donor hydrogen depletion, indicating that the solvent must be rehydrogenated in situ to provide solvent balance. Both observations show that, at these liquefaction conditions, donor hydrogen depletion relates to the extent of the liquefaction reactions, thus supporting the assumptions inherent in the method.

The isomerization of hydroaromatics to indan-like structures was found to be significant at coal liquefaction conditions. These reactions, which remove donatable hydrogen from the solvent, are accelerated by temperature and by iron ore.

\section{Determination of Phenolic-OH Content in Coal-derived Distillates and Resids by FTIR Spectroscopy $^{68,77}$}

In the characterization of recycle solvents, the concentration of total phenols has been used as an indicator of catalyst deactivation or of steady-state operation in liquefaction processes. The phenol content supplements other important chemical and structural characteristics of liquefaction solvents. The procedure described is used to determine the total phenolic - $\mathrm{OH}$ concentration of a sample in THF solution. Coal-derived distillate and THF-soluble resid samples may be analyzed by the method. The method uses the intensity (net absorbance) of the -OH stretch band of phenols in the infrared spectra. This method differs from similar infrared methods largely by employing a solvent that is much better for coal-derived materials. Thus, this method may be applied to a substantially larger fraction of the total material available from liquefaction streams. Solvents typically used for such analyses will dissolve only about one-half of the material amenable to analysis by this method.

This FTIR method offers certain advantages over the ${ }^{19} \mathrm{~F}-\mathrm{NMR}$ method previously used: it is simpler to perform, it takes less time per analysis, and it applies to tetrahydrofuran-(THF) soluble resids (for which the ${ }^{19} \mathrm{~F}-\mathrm{NMR}$ method performs poorly). These concentration data often are used to characterize and evaluate recycle oils, but the resids have, in general, 
been poorly characterized. Results show the method's reproducibility and its comparability to an accepted method ( $\left.{ }^{19} \mathrm{~F}-\mathrm{NMR}\right)$ for distillates.

\section{Liquid Column Fractionation: A Method of Solvent Fractionation of Coal Liquefaction And Petroleum Products $^{12}$}

A method was developed for the solvent fractionation of coal liquefaction and petroleum products which is both reproducible and considerably more rapid than many conventional solvent fractionation techniques. This method involves sequential elution of a sample injected onto an inert liquid chromatographic column. Applications of this method to coal liquefaction and petroleum products were demonstrated.

The LCF method is a viable alternative to the time-consuming Soxhlet method or other standard methods. While it cannot be expected to duplicate the results of the other methods, it is generally accepted that the various Soxhlet and other methods are not interchangeable. LCF is rapid, offers excellent reproducibility, and allows a change in solvents to be made without drastically altering the procedure. These advantages recommend it for consideration, particularly in those instances in which turn-around time is important.

\section{Correlation of Liquid Chromatographic Retention Times With Molecular Structures of Coal Liquid Components ${ }^{6}$}

The retention times of the components of a distillable coal liquid (b.p. ca. 200-500 EC), separated by reversed-phase liquid chromatography (RPLC) using a C18 column, were estimated based on a multiple linear regression correlation with 11 simple molecular structure descriptors. A stepwise methanol/water gradient was employed. The coal liquid components include alkylated and unalkylated aromatics, hydroaromatics and other naphthenoaromatics, heterocyclics, and phenols. A correlation coefficient of 0.989 was obtained. The predicted and observed retention times of the 153 components and groups of isomers differ by an average of $2.6 \mathrm{~min}$ in a $138 \mathrm{~min}$ RPC separation. Improved accuracy ( \pm 2.0 min average) was obtained for a set of 37 model coal liquid compounds.

\section{Carbon Isotope Analysis ${ }^{2}$}


It was demonstrated that, under appropriate circumstances, stable carbon isotope analysis can be an excellent method to determine the contributions of the individual feedstock to $\mathrm{coal} /$ petroleum coprocessing products and to follow the reaction pathways of the individual feedstocks. There are two primary considerations in applying this method: 1) the difference in the stable carbon isotopic compositions of the two feedstocks $\left(d^{13} C_{\text {coal }}-d^{13} C_{\text {petroleum }}\right)$; and 2) selective isotopic fractionation errors. An adequate difference in the isotope ratios of the coal and petroleum can be assured by selecting the appropriate coprocessing feedstocks. In the authors' experience, a difference of $2 \%$ is required and a difference of $4 \%$ is desired for acceptable precision and accuracy. Selective isotopic fractionation is a consequence of the coprocessing process. It is affected by processing severity, and most coprocessing operations are at high enough severity to induce significant isotopic fractionation. Nevertheless, errors introduced by isotopic fractionation can be corrected. The so-called universal correction method developed is a suitable method, in most cases.

It is well known that crude oils, and presumably coals, are not isotopically homogeneous. Chemical class fractions, such as saturates, aromatics, polyfunctional compounds and asphaltenes of single crude oils, have carbon isotope ratios that can differ by as much as $2 \%$ from one another; the more functional components are typically isotopically heavier. Coprocessing products of commercial interest, however, are, for the most part, those fractionated by boiling point and solubility, not chemical class. These are the products for which this method is designed to apply.

\section{Unconverted HDPE Extraction Method and Application $^{19,22,26,28}$}

To recover and measure incompletely converted high-density polyethylene (HDPE), and to determine its concentration in coal/waste co-liquefaction process stream samples, an analytical procedure was developed to extract HDPE from ash-containing process stream samples. The method is an extraction of HDPE from the sample using hot (150 EC) decalin (decahydronaphthalene), in which the HDPE is soluble. The method, verification tests, and application were described.

\section{Similarity of Products From Different Coals ${ }^{71}$}


On the basis of compositional data obtained for the lower molecular weight products of coal liquefaction, it appears that certain molecular structures or building blocks are common to different coals over a range of rank, both in the make-up fo the network and the molecular phase. The relative proportions of those components differ, as presumably does the manner in which they are bonded. There must also be changes in component type and distribution between coals of different rank caused by the processes occurring during coalification. Despite these uncertainties, any attempt to model coal structure must take into account these demonstrated similarities in the major structural components, or explain how such similar products can be produced from dissimilar starting materials. In addition, any structural model must account for the significant concentrations of paraffinic moieties in coal.

\section{Common Contaminants in Process Oils}

A major pitfall to the unsuspecting analysts making detailed analysis of coal liquefaction process oils is the presence of non-process-oil contaminants. CONSOL's experience is that there are four common contaminants.

1. Oils generated in continuous process units are frequently contaminated by Dowtherm A, a heat transfer fluid consisting of diphenyl ether and biphenyl, and its hydrogenated and hydrocracked products. At times, the contamination can be severe, especially if the oils are fractionated. For example, a low level of contamination in a full-range product will become highly concentrated in the distillation fraction boiling in the kerosene range. Contamination can be severe enough that the diphenyl ether component significantly raises the oxygen content of the kerosene fraction.

2. Phthalate esters (plasticizers) appear to be a nearly endemic, albeit minor, contaminant of process oils. They usually are noticeable only in detailed separations by gas chromatography (GC), and they are readily identified in gas chromatography/mass spectrometric (GC/MS) analysis by a prominent base peak in the mass spectrum at a mass/charge ratio $(\mathrm{m} / \mathrm{e})$ of 149 . 
3. Tetrahydrofuran (THF) is a very useful solvent for coal liquids. Most solvents, including THF, have a low boiling point, and they can be removed from the material of interest by evaporation or distillation. Residual unevaporated solvent, whether THF or other solvent, in samples and fractions generated in the laboratory is always a potential contaminant. However, industrial-grade THF is a special concern because it is preserved with butylated hydroxytoluene (BHT), which has a much higher boiling point than THF. Thus, if liquefaction samples are extracted or dissolved in preserved THF, they can become contaminated with substantial quantities of BHT after removal of the THF. We found this to be a very common and serious problem with material generated in batch liquefaction experiments at numerous institutions. One way around this problem is to use freshly distilled THF for all work in which products will be isolated. Caution: distilling THF may concentrate explosive peroxides in the distillation bottoms and may allow peroxide build-up in the distilled THF.

4. All direct liquefaction processes employ a recycle oil. During start-up operations, a start-up oil must be employed. It is typical that start-up oils are composed of anthracene oil, creosote oil, or their hydrogenated products. The same materials may be used as make-up oil during operations. These start-up/make-up oils may contaminate process oils for long times after their introduction into a continuous process unit, particularly if the unit has large surge capacity or if the process has a low purge rate of material in the boiling range of the start-up/make-up oil.

\section{Analytical Needs Assessment and Participants Program ${ }^{51,54}$}

An assessment was made of the status of analytical methodology associated with direct coal liquefaction technology. Sources of information included process developers and analytical chemists. The following major recommendations emerged from this assessment.

1. The overall communication between the process developer, and plant operator, and the analytical chemist must be improved. Many of the analytical needs which were expressed by the plant operator and process developers are often independently 
addressed by the analytical chemist. It is obvious that the goal of building the bridge between the two groups is an important one.

2. It is important to elucidate the nature of the higher molecular weight non-distillable (soluble and insoluble) residual materials which constitute a major portion of the process streams in the direct liquefaction process. These high molecular weight materials pose difficult problems for the analytical chemist; however, the behavior of these materials is of great importance to liquefaction process performance.

3. Characterization of the functional groups associated with the components of the coal liquefaction process streams is important for an improved understanding of the conversion of these materials into high quality net product.

4. The use of new computational techniques, such as chemometrics, should be applied to the interpretation of coal liquefaction analytical and operating data.

A literature survey was made to identify analytical methods and techniques for application to the analysis of coal-derived resids. These analytical methods and techniques were chosen because they were shown to be useful in the analysis of coal-derived materials and other high molecular weight, fossil fuel-derived materials such as tar sands, shale oils, and petroleum resids. The survey was focused on literature published between 1980 and 1991 . A second survey focused on literature published from 1991 onward, and a third on publications from 1994 onward.

An important aspect of CONSOL's support work was the evaluation of analytical methods for the application to coal liquefaction process development. The goal was to identify analytical techniques that can provide data useful for an improved understanding of liquefaction process chemistry, which, in turn, will provide guidance to planning and interpreting process research to reduce process costs. When this project was begun, it was recognized that considerable analytical expertise already existed. Therefore, the approach taken was to evaluate available analytical methods through application by analytical experts 
to coal liquefaction process samples, rather than to develop new methods. In all, 24 industrial, academic, and government labs, employing 30 analytical techniques, participated in this evaluation, referred to as the Participants Program.

A number of important analytical methods were found to be well advanced for application to coal liquefaction process development, in terms of both experimental protocol and data interpretation. These include ${ }^{1} \mathrm{H}$ and ${ }^{13} \mathrm{C}$ nuclear magnetic resonance (NMR) spectroscopy, field ionization mass spectrometry (FIMS), and electron spin resonance (ESR) spectroscopy combined with thermogravimetric analysis (TGA). These techniques provide chemical and molecular information on coal and coal liquids, including the coal-derived resids that are important intermediates on the reaction pathway from coal to distillate liquid products. In addition to these analytical techniques, an empirical method was evaluated for measuring the reactivity of coal-derived resids for conversion to distillate products. This empirical method (utilizing a Short Time Batch Reactor) promises to be useful in establishing resid conversion kinetics and the relationship of reactivity to resid chemistry. Finally, a set of petroleum inspection tests, which are routinely used to evaluate refinery feedstocks, was applied to coal-derived synthetic crude oils. The information obtained is useful for valuation of the synthetic crudes tested, and indicates the limitations of the standard petroleum methods for application to coal-derived liquids.

This work was described in five DOE technical reports: $89883-18,89883-70,89883-93$, 93054-14, 93054-67.

\section{Resid Reactivity Testing and Modeling ${ }^{15,18}$}

A review was conducted of the literature dealing with the modeling of fossil-fuel resid conversion to product oils. The literature cited in this report was published from 1994 onward. The kinetic models were grouped into two general approaches. One approach entails the choice of pseudo-components (or lumps) and an extension of the lumped modeling approach which utilizes continuous distribution mathematical representations of the lumps. The second approach is the construction of a structural model "built" using Monte Carlo techniques or other structure-building methods. These structures are then "reacted" 
based on the probability that they will undergo certain molecular scission and combination reactions. The properties of the 'reacted' system then are checked against measured properties of the materials being modeled.

Resid hydrocracking is a key reaction of modern (i.e., distillate-producing) coal liquefaction processes. Coals are readily converted to resid and lighter products in the liquefaction process. The resid is combined with fresh coal in a ratio often greater than 1:1 and some vacuum gas oil, and is recycled to be further converted. Understanding the chemistry of resids and resid reactivity is important to improve direct liquefaction process design and to achieve economic objectives for direct coal liquefaction. Computational models that predict resid conversion from the chemical characteristics of the resids and reaction conditions would be a cost-efficient way to explore process variables. Implementation of such models could aid in the design and operation of liquefaction facilities.

Under subcontract from CONSOL Inc., the University of Delaware studied the mechanism and kinetics of coal liquefaction resid conversion. It consisted of two primary tasks. The first task was to develop an empirical test to measure the reactivity of coal-derived distillation resids. From this empirical test, simple kinetic parameters were developed to define the resid reactivity. The second task was to formulate a computer model to represent the structure of the resids and a kinetic and mechanistic model of resid reactivity based on the structural representations.

Both tasks described above were successfully accomplished. An empirical test was developed for coal liquefaction resids. The test made use of a small batch reactor system, which was constructed at the University of Delaware. The reactor system allows for short reactant heat-up times and product cool-down times, permitting the acquisition of kinetic data. To evaluate products, a method was developed to determine boiling point distribution using thermogravimetric analysis techniques.

The reactivity test was applied to a suite of fifteen well-characterized $850 \mathrm{EF}^{+}$distillation resids. The resids were derived from the Wilsonville pilot plant and the Hydrocarbon 
Technology, Inc. (HTI) bench unit. Feed coals included Illinois 6 bituminous coal, Pittsburgh seam bituminous coal, and Wyodak and Anderson seam subbituminous coal. The resids were produced by distillation of process stream samples obtained from several sampling locations in the plants. Reaction conditions were chosen to produce (on average) conversions similar to those obtained on a single pass in the continuous plants from which the samples were obtained (about $30 \mathrm{wt} \%$ ). Resid conversion values were determined for each resid under this one set of conditions. To obtain kinetic data, two of the fifteen resids also were reacted at several residence times and two temperatures. Some relationships were found between the resid conversion and resid concentration, hydrogen pressure, and catalyst concentration. However, no simple correlation was found between conversion and the chemical characteristics of the resids. Conversions of resid to distillate obtained thermally and catalytically are significantly different. Kinetic data, although limited, indicate that a component of the resids is not convertible. An unconvertible insoluble resid component was isolated.

Chemical characteristics supplied to Delaware by CONSOL, and the results of the reactivity tests were used to construct mathematical structural representations of the resids. The structural representations then were subjected to a set of reaction rules. The outcome of the calculations was a resid conversion value for each resid. Correlation between the model output and experimental results was good. However, the model constructed in this study is viewed as "first generation" and now is ready for further refinement and expansion.

\section{PROCESS ACCOMPLISHMENTS}

\section{Process Development for Improved SRC Options: Short Residence Time Studies ${ }^{117}$}

The objective of the program was to investigate improvements to the Solvent Refined Coal (SRC-1) process, including the use of short residence times, critical solvent deashing and selective product recycle. This work, which was performed in both batch and $10 \mathrm{lb} / \mathrm{hr}$ continuous liquefaction and trickle-bed hydrogenation equipment, was highly successful. It demonstrated for the first time that "heavy" solvents are highly effective for liquefaction and desulfurization, as well as underscoring the importance of solvent quality. SRC-1 solvent quality was shown to deteriorate as it evolved, and the chemical causes of this deterioration 
were discovered. A ${ }^{1} \mathrm{H}-\mathrm{NMR}$ method was developed to quantitatively measure solvent hydrogen donation as part of this program. This work proved the technical validity of the concept of short residence time liquefaction coupled with critical solvent deashing and certainly gave the driving force to its adoption at the Wilsonville pilot plant. This later allowed two-stage operations to be tested there.

\section{Coal Liquefaction and Deashing Studies of the CSF and SRC Processes ${ }^{118}$}

This program was designed to develop anti-solvent deashing for application in the Consol Synthetic Fuels (CSF) and SRC liquefaction processes. Tests were conducted on a $10 \mathrm{lb} / \mathrm{hr}$ continuous liquefaction unit which simulated the CSF and SRC processes. Specification product $(<0.2 \%$ ash in SRC) was produced with high product recovery. A conceptual commercial anti-solvent deashing unit was designed.

\section{$\underline{\text { Retrograde Reactions }}^{10}$}

Four runs were made using a $10 \mathrm{lb}$ coal/hr continuous bench-scale liquefaction unit to study the occurrence of retrograde reactions at high-temperature (840 EF), high-pressure separator conditions in SRC-I liquefaction. Samples of high-, medium- and low-pressure separator inventories taken at residence times of 5-10 $\mathrm{min}$ and separator temperatures of 640-840 EF were analyzed to examine the nature and extent of solids-forming reactions. Viscosities of selected reactor products were measured at 240-840 EF and petrographic analyses were made of separator solids.

At SRC-I liquefaction conditions, retrograde reactions involve the conversion of a relatively small percentage of the product, $1-2 \%$, to THF-insolubles. The principal retrograde reactant is the preasphaltene fractions. For an SRC-I unit utilizing critical solvent deashing (CSD) for solids separation, these reactions would have little effect on the final product yield distribution. This is because the CSD unit preferentially rejects the preasphaltenes with the ash concentrate. Therefore, the conversion of small amounts of preasphaltenes to THFinsolubles would have little effect on yields. 
The solids formed in these retrograde reactions are fine-grained isotropic particles (vitroplast) and not "coke". These particles will not impede separator operations if flow in the separators is sufficient to prevent their accumulation.

If agitation is insufficient, vitroplast particles will agglomerate and, with time at temperature, convert to coarser-grained anisotropic carbon (coke). In time, this accumulated material would be expected to significantly impede separator operation.

Of the variables studied, the high-pressure separator temperature has the most pronounced effect on insolubles formation, particularly at low hydrogen partial pressures. Variations in residence time, from 5 to $10 \mathrm{~min}$ in each separator, which are consistent with the design basis of the SRC-I demonstration plant did not have an effect on solids formation.

The separator inventory is a low-viscosity material $(0.4 \mathrm{mPas}(\mathrm{cP})$ at $722 \mathrm{~K}$ under hydrogen). At $611 \mathrm{~K}$, the lowest separator temperature used in the continuous unit study, viscosity increased to only $4.1 \mathrm{mPas}(\mathrm{cP})$ under four hours at $611 \mathrm{~K}$. Viscosity did not vary with time at temperature except for the catastrophic changes at $722 \mathrm{~K}$.

High-temperature operation of the pressure let-down system in the SRC-I process should not have a detrimental effect on process performance. Retrograde reactions that might occur will not appreciably affect net product distributions. Potential operating problems, caused by accumulation of solids in the high pressure separator, can be avoided by the appropriate separator design, which is within the scope of current practice.

\section{Evaluation of Recycle Solvent Quality ${ }^{11,59,60,90,95}$}

SRC-1 Oils. Recycle distillates (solvents) from the Wilsonville, AL, SRC-I pilot plant were analyzed by a variety of methods, and the composition data related to the performance of the solvents in both batch and continuous unit coal liquefaction. Because of its low distillate yield, solvents in the SRC-I process evolve rather slowly from the anthracene oil start-up solvent to steady-state, process-derived distillates. As the steady-state solvent evolves, it increases in saturates and mono-aromatic hetero molecules (primarily phenols and indanols), 
and its quality as a liquefaction medium declines. Because it is low in condensed aromatics, the steady-state SRC-I solvent cannot be greatly improved by hydrogenation. Other analytical data were provided that describe the composition of SRC-I recycle distillates. The analytical methods used in this work are of adequate simplicity that they could serve as routine monitoring methods in SRC-I liquefaction.

Based on the results, the following conclusions concerning the nature and evolution of the recycle solvent in the SRC-I process were made.

The evolution of a process-derived SRC-I recycle solvent involves increases in saturates and hetero species at the expense of the condensed aromatics. The increase in concentrations of these species may be a direct result of their production from the coal, but may also reflect the low rate of distillate production in the SRC-I process. That is, at typical distillate makes of a few percent of the solvent per pass through the liquefaction reactor, the recycle distillate in the SRC-I process has a "half-life" of perhaps 20 cycles. At the rather severe hydrogenation conditions $\left(450 \mathrm{EC}, 13.8 \mathrm{MPa}_{2}\right)$ in the $\mathrm{SRC}$-I reactor, hydrocracking is likely to result, in preference to the more mild hydrogenation reactions, which can produce hydroaromatic donor molecules.

As the solvent evolves in the SRC-I process, it becomes a poorer liquefaction medium. Both microautoclave and continuous unit performance data support this, and similar conclusions can be inferred from data reported by Wilsonville. This decrease in solvent quality is accompanied by an increase in saturates, monoaromatic hetero molecules, and alkylated aromatics, at the expense of less alkylated condensed and hydroaromatics.

Hydrogenation of the near-start-up solvent results in a significant improvement in the hydrogen donor properties of the solvent. Hydrogenation of the more highly alkylated "equilibrium" solvent gives a smaller increase in hydrogen donor ability, and the solvent is easily overhydrogenated. 
The problem of continuously declining solvent quality in the SRC-I process may be solved by recycling a non-distillate product fraction as a major portion of the total recycle. For example, the recycle of light SRC, separated by the Kerr-McGee deashing process, was demonstrated to greatly improve the SRC-I solvent properties. In general, the recycle of vacuum bottoms as a slurry oil component may have beneficial effects in the thermal hydroliquefaction of coal.

The two largest components in all of the Wilsonville-derived solvents described in this work, biphenyl and diphenyl ether, are artefacts caused by the contamination of the liquefaction solvent by the heat transfer medium, Dowtherm.

H-Coal Oils. Daily samples of the two recycle slurry oil streams from H-Coal PDU Runs 5, 8 , and 9 were analyzed by a variety of techniques and the data interpreted in light of process performance. The results show that $\mathrm{H}$-Coal recycle distillates are uniformly good hydrogen donor liquefaction media, regardless of coal or space velocity, although the recycle distillates from the Syncrude mode runs (PDU Runs 5 and 9) are somewhat superior to those from the Fuel Oil and (particularly) Intermediate modes (PDU Run 8). The recycle resids show greater diversity, with those from the Fuel Oil mode having twice the preasphaltene content of the recycle resids from the two Syncrude mode runs.

A statistical treatment of the data to determine the approach of the recycle oils in the various $\mathrm{H}-\mathrm{Coal}$ PDU operations to a steady state composition leads to the following conclusions.

- The majority of the data indicates that the recycle resid composition, but not recycle rate, had reached steady state by day $10-15$ of PDU Runs 5 and 9 .

- The recycle distillate composition did not reach steady state in PDU Run 9, but did in PDU 5. 
- Start-up solvent is rapidly replaced in H-Coal PDU operation. Any aromatic start-up solvent of the appropriate boiling range should suffice if it is physically compatible with the coal liquids.

- The aromaticity of the recycle oil increases during the run with declining catalyst activity. The same is true for the hydroxyl contents of the recycle distillates.

- The recycle resid in PDU Run 8 (Fuel Oil and Intermediate modes) was much higher in preasphaltenes, in functional components, and in molecular weight than from either PDU Runs 5 or 9 . This may have been related either as cause or effect to the operability problems encountered in PDU Run 8.

- Recycle distillates are qualitatively similar, regardless of the mode or the feed coal. All are good liquefaction media.

- PDU Runs 5 and 9 data indicate a fast catalyst deactivation for resid hydrogenation (10 to 15 days) and a slower catalyst deactivation for distillate hydrogenation (greater than 30 days).

- Kentucky 9 and Illinois 6 coals give similar slurry recycle oils at the Syncrude mode. Differences among the Fuel Oil, Intermediate, and Syncrude space velocities with the same coal are greater.

General. Both microautoclave extractions and ${ }^{1} \mathrm{H}-\mathrm{NMR}$ spectra can provide relative rankings of SRC-I liquefaction solvents. The microautoclave method has the advantage of being a direct, if empirical, measurement of the ability of the solvent to liquefy coal, at least in the hydrogen donor mode. The ${ }^{1} \mathrm{H}-\mathrm{NMR}$ method has the advantage that its application is not constrained by the uncertain ability to maintain a standard coal, as is the case with the microautoclave method. Sample throughput is 5-10 times faster with the ${ }^{1} \mathrm{H}-\mathrm{NMR}$ method. 
Solvent quality generally improves with moderation of solvent hydrogenation conditions. Hydrogenation severity in the SRC process, although not catalytic, is greatly increased by the large number of cycles necessary to replace the distillate solvent. In the $\mathrm{H}$-Coal and ITSL processes, the solvent turn-over is rapid. The option of recycling residual materials, available in the H-Coal and ITSL processes but not in SRC-I, also has a beneficial effect on recycle solvent quality. The degree of flexibility available in selecting different streams for recycle increases the opportunity for the process operator to optimize recycle composition. A two-stage liquefaction process, and, in particular, one in which the solvent deashing allows selective separation of the residual coal-derived liquids, affords the greatest opportunity to tailor recycle solvent quality to process needs.

The evolution of coal liquefaction technology from a single-stage catalytic process to a twostage thermal/catalytic process, to the current two-stage catalytic/catalytic processes has been accompanied by corresponding changes in the characteristics of the process and recycle oils. The catalytic/catalytic process configuration minimizes the concentrations of undesirable components, such as phenolics, aromatics, and preasphaltenes, throughout the liquefaction system. At the same time, recycle solvent qualities are uniformly good, and are generally improved by the presence of hydrogenated residual oils.

\section{Improvement in Coal Liquefaction Solvent Quality by Dewaxing ${ }^{8}$}

Recycle oils from the Integrated Two-Stage Liquefaction (ITSL), H-Coal, and Solvent Refined Coal (SRC) processes were dewaxed by variants of commercial dewaxing processes (the ketone and urea adduction techniques) yielding up to $47 \mathrm{wt} \%$ "wax". Feed oils and product fractions were characterized by elemental analysis, ${ }^{1} \mathrm{H}-\mathrm{NMR}$, and gas chromatography. The clean waxes were nearly pure mixtures of $n$-paraffins. The dewaxed oils were substantially better coal liquefaction solvents than the original (non-dewaxed) oils in batch liquefaction tests. For example, in one case, dewaxing improved the conversion of a bituminous coal to tetrahydrofuran solubles under standard reaction conditions from $71 \mathrm{wt}$ $\%$ (dafb) with the original oil to $87 \mathrm{wt} \%$ (dafb). These data provide a direct indication of the inimical effect of paraffinic components on solvent quality. The impact of solvent quality is particularly relevant to liquefaction processes in which thermal reactions proceed in a recycle 
solvent. In addition, the results indicate the technical feasibility of dewaxing coal liquefaction recycle oils by commercially available technology to improve solvent quality and to produce a useful by-product. Dewaxing could be applied in any liquefaction process that uses a deasphalted (preferably distillate) recycle stream.

\section{Oil Agglomeration as a Pretreatment for Coal Liquefaction ${ }^{4,8}$}

Laboratory experiments demonstrated that a variety of distillate coal liquefaction recycle oils were satisfactory agents for cleaning Illinois 6 bituminous coal by oil agglomeration. Ash rejection up to $41 \%$ with $98 \%$ organic recovery was attained with conventionally cleaned coal, and ash rejection up to $67 \%$ with $90 \%$ organic recovery with run-of-mine coal. Agglomerates of $>1 \mathrm{~mm}$ average diameter were produced under a variety of conditions. Similar results were obtained in the scaled-up production of $268 \mathrm{~kg}$ of agglomerates. Oils with lower hydrogen aromaticities and higher hydrogen contents performed better than more aromatic oils. $\mathrm{Fe}, \mathrm{Ti}$, and $\mathrm{Mg}$ were selectively enriched in the ash of the product coal, while $\mathrm{Ca}, \mathrm{Si}$, and $\mathrm{Al}$ were selectively rejected. The mineral pyrite was rejected only . $30-40 \%$ as extensively as the bulk of the ash-forming minerals. The coal cleaned by oil agglomeration performed similarly to the feed coal in batch donor liquefaction tests. In continuous hydroliquefaction tests, run-of-mine coal cleaned by oil agglomeration performed substantially better than coal cleaned to the same ash level by conventional means, because of the selective enrichment of catalytic iron minerals

Laboratory experiments demonstrated that low-rank coals can be cleaned by agglomeration with distillate coal liquefaction recycle oils. Materials tested included a lignite, three subbituminous coals, a bituminous coal, two petroleum oils, and three coal liquefaction recycle oils. Ash rejections obtained were as high as $~ 50 \%$ for Texas lignite and $15-20 \%$ for two Wyoming subbituminous coals. A Montana subbituminous coal showed no ash rejection, although physical agglomeration occurred. Organic recoveries for the low-rank coal tests were always $>98 \%$. all three liquefaction recycle distillates tested were effective agglomerating agents for low-rank coals. In the few cases tested, adjustment of the slurry $\mathrm{pH}$ to 2.0 or addition of cresylic acid to the slurry had beneficial effects for the lignite agglomeration. Selectively retained in the product ash were Fe (a potential liquefaction 
catalyst), $\mathrm{Ti}, \mathrm{Ca}$, and $\mathrm{Mg}$, whereas $\mathrm{Na}$ was selectively rejected. This work shows that lowrank coals can be cleaned by agglomeration with coal liquefaction oils. to the author's knowledge, this is the first time that this has been demonstrated. It is expected that agglomeration performance, e.g., ash rejection and induction time, could be further improved through additional testing.

\section{Testing of Advanced Liquefaction Concepts in HTI Run ALC-1: Coal Cleaning and Recycle Solvent Treatment $^{21,24,25,27}$}

In 1991, the Department of Energy initiated the Advanced Liquefaction Concepts Program to promote the development of new and emerging technology that has potential to reduce the cost of producing liquid fuels by direct coal liquefaction. Laboratory research performed by researchers at CAER, CONSOL, Sandia, and LDP Associates in Phase I was tested at the bench scale at HTI. HTI Run ALC-1, conducted in the spring of 1995, was the first of four planned tests. In Run ALC-1, feed coal ash reduction (coal cleaning) by oil agglomeration, and recycle solvent quality improvement through dewaxing and hydrotreatment of the recycle distillate were evaluated. Liquefaction process performance was compared to previous results from Wilsonville pilot plant and HTI bench scale runs. Implications of these results for liquefaction economics were evaluated.

There were four main objectives for Run ALC-1: 1) provide a baseline operating period with Black Thunder Mine subbituminous coal, 2) demonstrate liquefaction of low ash coal produced by oil agglomeration of Black Thunder Mine coal at low $\mathrm{pH}, 3$ ) demonstrate liquefaction of Black Thunder Mine coal with dewaxing and hydrotreatment of distillate solvent, and 4) operate with extinction recycle of $343 \mathrm{EC}^{+}$material, such that a hydrotreated light distillate would be the intended net product. An additional objective was to exploit the advantages of the low-ash coal concept by decreasing the fresh catalyst make-up rate with the lower ash agglomerated feed.

HTI's bench liquefaction Run ALC-1consisted of 25 days of operation. Major accomplishments were: 1) oil agglomeration reduced the ash content of Black Thunder Mine coal by $50 \%$, from $5.5 \%$ to $3.3 \%$ (MF, $\mathrm{SO}_{3}$-free ash basis); 2) excellent coal conversion of 
98\% was obtained with oil agglomerated coal, about $3 \%$ higher than the raw Black Thunder Mine coal, increasing the potential product yield by $2-3 \%$ on an MAF coal basis; 3 ) agglomerates were liquefied, with no handling problems; 4) fresh catalyst make-up rate was decreased by $30 \%$, with no apparent detrimental operating characteristics, both when agglomerates were fed and when raw coal was fed (with solvent dewaxing and hydrotreating); 5) recycle solvent treatment by dewaxing and hydrotreating was demonstrated, but steady-state operation was not achieved; and 6) there was some success in achieving extinction recycle of the heaviest liquid products. Run ALC-1 generated the highest distillate yield ever reported, to our knowledge, for subbituminous coal. More details appear in Chapter 2 of this report.

\section{$\underline{\text { Recycle Oils from Fluid Coking of Coal Liquefaction Bottoms }}{ }^{5}$}

Ten fluid-coker tars, produced by Lummus-Crest, Inc., from coal liquefaction vacuum bottoms, were characterized to evaluate their use as liquefaction recycle oils. The primary variables in the coking tests were temperature (1000-1200 EF) and coker feedstock source. Most of the properties of the tars are principally influenced by the coking temperature. Those produced at higher temperature are ore aromatic, they contain more carbon and less hydrogen, and they are principally unsubstituted and methyl-substituted condensed aromatic compounds. The heteroatom contents of the tars appear to be determined mainly by the coker feedstock; however, heteroatom contents are quite low for these tars. The tars produced at $1000 \mathrm{EF}$ are expected to be poor hydrogen donor solvents, whereas those produced at $1200 \mathrm{E}$ can donate virtually no hydrogen. However, a $1200 \mathrm{EF}$ tar was readily hydrotreated to produce an excellent donor solvent. None of the tars produced at 1000 or $1100 \mathrm{EF}$ was hydrotreated. Since the properties of those tars are different than those produced at $120 \mathrm{E}$, they may respond differently to hydrotreating. However, the difference is such that the tars produced at lower temperature are more similar to their feedstock. Therefore, it is expected that their susceptibility to hydrotreating should be intermediate between that of their feedstocks and that of the high-temperature coker tars. On the basis of these results, it would appear that tars produced from fluid coking of liquefaction vacuum bottoms can be recycled to a catalytic liquefaction reactor to produce additional liquids 
without adversely affecting process performance. The impact of the coker tars on long-term catalyst activity remains to be addressed.

\section{High Quality Gasoline Feedstocks from the Direct Liquefaction of Coal ${ }^{17,39,40,46,49,55}$}

The high quality of coal-derived gasoline feedstock (naphtha) from modern two-stage coal liquefaction facilities is apparent in the analyses of fourteen samples obtained from eight tests made at three facilities over a period of six years. This high quality is attributable to the high naphthene contents, low aromatics, low olefins content, and low heteroatom contents. Only mild hydrotreating or adding inhibitors to alleviate acidity is indicated to produce a gasoline blending stock from the coal-derived naphthas, which are otherwise excellent reformer feedstocks.

\section{Jet Fuel from Direct Coal Liquefaction ${ }^{17,39,40,46,49,55}$}

The quality of the 180-300 EC distillation-fraction of nine direct coal liquefaction products was assessed by comparison of physical and chemical property test data to the corresponding specifications for aviation turbine fuels. Petroleum inspection tests were employed to evaluate the samples. Although it is acknowledged that these tests were not designed for analysis of coal liquids, they provide the best available methods for evaluation of the quality and value of the direct coal liquefaction product oils. In general, the coalderived distillation fractions are too cyclic (aromatic, naphthenic) for use as commercial Jet A-1 aviation fuel and were shown in this work to require additional hydrotreating to meet Jet A-1 specifications. Instead of extensive hydrotreating, this fraction could be distributed in the refinery into the diesel fuel and gasoline feedstocks. However, its high volumetric energy content and compositional uniqueness (its naphthenic content, which makes the distillation cut unacceptable for Jet A-1), make this material an attractive feedstock for high energydensity jet fuel. A single source for these results is DOE Topical Report 93054-79.

\section{Caustic Washing to Refine Products and Isolate Phenolics ${ }^{34}$}

Caustic washing was found to be highly efficient and highly selective for the extraction of phenolics from the light distillate fractions (b.pt. $<510 \mathrm{EF}$ ) of the products of modern twostage direct coal liquefaction products. The extracts were composed almost entirely of 
phenolics and the lower boiling raffinates were almost devoid of phenolics. The properties of the raffinates as feedstocks or blendstocks for transportation fuels were moderately improved relative to the unextracted materials. Notable improvements included reduced acidity, mercaptan sulfur, oxygen, and copper corrosion; other minor improvements also were seen. The composition of the caustic extracts (cresylic acids) depends on the boiling point of the material extracted, but primarily consists of phenols with zero to four alkyl substituents.

\section{Preparation of Alkyl Aryl Ethers from Coal Derived Phenols and Testing as Diesel Fuel Extenders}

CONSOL R\&D evaluated reactions to synthesize alkyl phenyl ethers from coal liquefaction phenols. The program included a literature review and laboratory chemical syntheses. Phenols are produced during the direct liquefaction of coal and must be removed prior to producing transportation fuels. The crude liquefaction product is commonly hydrotreated to remove the phenols and other unsaturated components. An alternative method is to extract the phenols from the crude coal liquefaction product and use them in other commercial processes. Hydrogen consumption for the hydrotreatment would be reduced, and the phenolic material could be converted to alkylphenyl ethers. Alkylphenyl ethers may be useful as fuel extenders. A literature search identified the Williamson Synthesis and its modifications as the preferred methods to produce mixed ethers from phenols. A variation of the Williamson Synthesis was used to produce phenetole and the ethyl derivatives of the phenolics from a caustic extract of a crude direct coal liquefaction product. Other approaches involving acid catalysts failed to produce ethers.

Four blends of ethylphenyl ether 160-337 EC distillate and diesel fuel were made and tested with a sample of the unadulterated diesel fuel. Ethylphenyl ethers are not useful as cetane enhancers because of their negative effect on the cetane number of the fuel. However, ethylphenyl ethers may be useful diesel fuel extenders. Their production from phenols native in coal liquids plus grain alcohol could reduce the overall hydrogen consumption in the coalto-finished-fuels chain. Potentially, tax credits could be earned for the use of grain alcohol in the fuel production process. 
This work was described in two DOE technical reports,93054-46, and 93054-61.

\section{Direct Coal Liquefaction Promoted by Hydride Ion Transfer ${ }^{1,29,105}$}

The effectiveness of low-severity, chemically-induced, hydride-ion-promoted coal dissolution was demonstrated. Low-severity reaction conditions were determined for which high coal conversion (>90 wt \%) to soluble products were obtained with five different coals of three different ranks. The effects on coal conversion of temperature, residence time, coal rank, hydride ion reagent-to-coal ratio, heating rate, and solvent type were determined. The coalderived soluble products are enriched in hydrogen and depleted in oxygen relative to the starting coal. Various hydride-ion agents were tested, including methyl formate, formic acid, ammonium formate, potassium formate, and alkaline carbon monoxide.

High coal conversions of greater than $90 \mathrm{wt} \%$ with coals of three ranks can be achieved at low-severity conditions by a hydride ion promoted reaction. The high coal conversions are obtainable at temperatures in the range of 350-400 EC, at short-to-moderate residence times (30 to $60 \mathrm{~min}$ ), and at low to moderate pressure (6.9-27.6 MPa). It is concluded that the high coal conversions to THF-soluble products can be achieved in part because the occurrence of retrograde or secondary reactions to intractable, insoluble materials is minimized at the low reaction temperatures. It was found that some solvent is necessary to achieve high coal conversions and that the aromaticity of the solvent is important for high coal conversions at the lowest severity reaction conditions. The products of reaction are reduced in oxygen content and enriched in hydrogen content.

\section{BIBLIOGRAPHY FOR CHAPTER 8}

\section{Peer-Reviewed Publications}

1. Brandes, S. D.; Winschel, R. A. "Direct Coal Liquefaction Promoted by Hydride Ion Transfer", submitted for publication to Fuel, April 20, 1999.

2. Lancet, M. S.; Winschel, R. A.; Burke, F. P. "Stable Carbon Isotope Analysis of Coprocessing Materials", Fuel 1993, 72, 1209-1217. 
3. Miknis, F. P.; Netzel, D. A.; Brandes, S. D.; Winschel, R. A.; Burke, F. P. "N.M.R. Determination of Aromatic Carbon Balances and Hydrogen Utilization in Direct Coal Liquefaction", Fuel 1993, 72, 217-224.

4. Robbins, G. A.; Winschel, R. A.; Amos, C. L.; Burke, F. P. "Agglomeration of LowRank Coal as a Pretreatment for Direct Liquefaction", Fuel 1992, 71, 1039-1046.

5. Winschel, R. A.; Burke, F. P. "Recycle Oils From Fluid Coking of Coal Liquefaction Bottoms", Energy \& Fuels 1989, 3, 437-443.

6. Burke, F. P.; Winschel, R. A. "Correlation of Liquid Chromatographic Retention Times with Molecular Structures of Coal Liquid Components", Analytical Chemistry 1987, 59, 2586-2593.

7. Winschel, R. A.; Burke, F. P. "Oil Agglomeration as a Pretreatment for Coal Liquefaction", Fuel 1987, 66, 852-858.

8. Winschel, R. A.; Robbins, G. A.; Burke, F. P. "Improvement in Coal Liquefaction Solvent Quality by Dewaxing", Fuel 1987, 66, 654-660.

9. Winschel, R. A.; Robbins, G. A.; Burke, F. P. "Correlation of Microautoclave and ${ }^{1} \mathrm{H}-$ NMR Measurements of Coal Liquefaction Solvent Quality", Fuel 1986, 65, 526-532.

10. Burke, F. P.; Winschel, R. A.; Jones, D. C. "Retrograde Reactions in SRC-1 Liquefaction", Fuel 1985, 64, 15-21.

11. Burke, F. P.; Winschel, R. A.; Pochapsky, T. C. "Composition and Performance of Distillate Recycle Solvents from the SRC-1 Process", Fuel 1981, 60, 562-572.

12. Burke, F. P.; Winschel, R. A.; Wooton, D. L. "Liquid Column Fractionation: A Method of Solvent Fractionation of Coal Liquefaction and Petroleum Products", Fuel 1979, 58, 539-541.

13. Kleinpeter, J. A.; Jones, D. C.; Dudt, P. J.; Burke, F. P. "Coal Liquefaction and Deashing Studies. 1. CONSOL Synthetic Fuel Process", Ind. Eng. Chem. Proc. Des. Dev. 1979, 18, 535.

14. Kleinpeter, J. A.; Jones, D. C.; Dudt, P. J.; Burke, F. P. "Coal Liquefaction and Deashing Studies. 2. Solvent Refined Coal Process", Ind. Eng. Chem. Proc. Des. Dev. 1979, 18, 541.

\section{Formally Presented Papers}

15. Brandes, S. D.; Winschel, R. A.; Calkins, W. H.; Klein, M. T.; Huang, H.; Campbell, D.; Wang, S.; Wang, K. "The Reactivity of Direct Coal Liquefaction Resids" 
presented atthe International Conference on Coal Utilization and Fuel Systems, Clearwater, FL, March 1998.

16. Winschel, R. A.; Robbins, G. A. "Characterization of Process Oils from Coal/Waste Co-Liquefaction", presented at the 14th AIST-NEDO/DOE-FETC Joint Technical Meeting on Coal Liquefaction and Materials for Coal Liquefaction, Tokyo, Japan, October 1997.

17. Zhou, P.-Z.; Srivastava, R. D.; Winschel, R. A. "Characterization of Liquid Products from All-Slurry-Mode Direct Liquefaction", presented at the 1997 DOE Coal Liquefaction and Solid Fuels Contractors Review Conference, Pittsburgh, PA, September 1997.

18. Brandes, S. D.; Winschel, R. A.; Calkins, W. H.; Klein, M. T.; Huang, H.; Campbell, E.; Wang, S.; Wang, K. "The Reactivity of Direct Coal Liquefaction Resids", presented at the 1997 DOE Coal Liquefaction and Solid Fuels Contractors Review Conference, Pittsburgh, PA, September 1997.

19. Robbins, G. A.; Winschel, R. A. "Characterization of Process Samples from CoLiquefaction of Coal and Waste Polymers", presented at the 1997 DOE Coal Liquefaction and Solid Fuels Contractors Review Conference, Pittsburgh, PA, September 1997.

20. Givens, E.; Anderson, R.; Demirel, B.; Derbyshire, F.; van Wort, H.; Xiaodong, Z.; Winschel, R; Robbins, G.; Burke, F.; Peluso, M.; Hu, J; Lee, T. "Bench-Scale Testing of Advanced Concepts for Direct Coal Liquefaction: Evaluation of Dispersed Mo Catalysts", presented at the 1997 DOE Coal Liquefaction and Solid Fuels Contractors Review Conference, Pittsburgh, PA, September 1997.

21. Winschel, R. A.; Robbins, G. A.; Hu J. "Oil Agglomeration at Low $\mathrm{pH}$ as a Pretreatment for Liquefaction of Wyoming (USA) Subbituminous Coal", presented at the Ninth International Conference on Coal Science, Essen, Germany, September 1997.

22. Robbins, G. A.; Winschel, R. A. "Characterization of Process Stream Samples from Bench-Scale Co-Liquefaction Runs That Utilized Waste Polymers as Feedstocks" presented at the 214th, Annual Meeting of the American Chemical Society, Las Vegas, NV, September 1997.

23. Burke, F. P.; Winschel, R. A.; Gray, D. "Recent Advances and Future Prospects for Direct Coal Liquefaction Process Development" presented at the 213th Annual Meeting of the American Chemical Society, San Francisco, CA, April 1997.

24. Robbins, G. A.; Winschel, R. A.; Burke, F. P.; Derbyshire, F. J.; Givens, E. N.; Hu, J; Lee, T. L. K.; Miller, J. E.; Stephens, H. P.; Peluso, M. "Testing of Advanced Liquefaction Concepts in HTI Run ALC-1: Coal Cleaning and Recycle Solvent 
Treatment", presented at the U.S./Japan Joint Technical Workshop, State College, PA, October 1996.

25. Robbins, G. A.; Winschel, R. A.; Burke, F. P.; Derbyshire, F. J.; Givens, E. N.; Hu, J; Lee, T. L. K.; Miller, J. E.; Stephens, H. P.; Peluso, M. "Testing of Advanced Liquefaction Concepts in HTI Run ALC-1: Coal Cleaning and Recycle Solvent Treatment", presented at the 13th Annual International Pittsburgh Coal Conference, Pittsburgh, PA, September 1996.

26. Robbins, G. A.; Winschel, R. A.; Burke, F. P. "Determination of Unconverted HDPE in Ashy Coal/Plastics Co-Liquefaction Stream Samples", presented at the 212th Annual Meeting of the American Chemical Society, Orlando, FL, August 1996.

27. Robbins, G. A.; Winschel, R. A.; Burke, F. P.; Derbyshire, F. J.; Givens, E. N.; Hu, J; Lee, T. L. K.; Miller, J. E.; Stephens, H. P.; Peluso, M. "Testing of Advanced Liquefaction Concepts in HTI Run ALC-1: Coal Cleaning and Recycle Solvent Treatment", DOE First Joint Power and Fuel Systems Contractors Conference, Pittsburgh, PA, July 1996.

28. Robbins, G. A.; Winschel, R. A.; Burke, F. P. "Determination of Unconverted HDPE in Ashy Coal/Plastics Co-Liquefaction Stream Samples", presented at the DOE First Joint Power and Fuel Systems Contractors Conference, Pittsburgh, PA, July 1996.

29. Brandes, S. D.; Winschel, R. A.; Burke, F. P.; Derbyshire, F. J.; Kimber, G. M.; Anderson, R. K.; Carter, S. D.; Peluso, M. "Exploratory Research on Novel Coal Liquefaction Concept" presented at the U.S. DOE Joint Power and Fuel Systems Contractors Conference, Pittsburgh, PA, July 1996.

30. Robbins, G. A.; Brandes, S. D.; Winschel, R. A.; Burke, F. P. "Characteristics of Process Oils From HTI Coal/Plastics Co-Liquefaction Runs", presented at the DOEPETC/AIST-NEDO Joint Technical Meeting, Sendai, Japan, October 1995.

31. Burke, F. P.; Winschel, R. A. "The Role Of Process Oil Characterization In Direct Coal Liquefaction", presented at the Twelfth Annual International Pittsburgh Coal Conference, Pittsburgh, PA, September 1995.

32. Robbins, G. A.; Brandes, S. D.; Winschel, R. A.; Burke, F. P. "Characteristics of Process Oils From HTI Coal/Plastics Co-Liquefaction Runs", presented at the 1995 DOE Coal Liquefaction and Gas Conversion Contractors Review Conference, Pittsburgh, PA, August 1995.

33. Anderson, R.; Derbyshire, F.; Givens, E.; Hager, T.; Kimber, G.; Lim, J.; Burke, F.; Lancet, M.; Robbins, G.; Winschel, R.; Stephens, H.; Kottenstette, R.; Peluso, M. "Advanced Process Concepts For Direct Coal Liquefaction", presented at the 1995 DOE Coal Liquefaction and Gas Conversion Contractors Review Conference, Pittsburgh, PA, August 1995. 
34. Winschel, R. A.; Zhou, P.-Z.; Burke, F. P.; Robbins, G. A.; Brandes, S. D. "Caustic Washing for Refining of Direct Coal Liquefaction Products", presented at the 210th Meeting of the American Chemical Society, Chicago, IL, August 1995.

35. Robbins, G. A.; Winschel, R. A.; Burke, F. P. "Characteristics of Process Oils From $\mathrm{HTI}$ Coal/Plastics Co-Liquefaction", presented at the Ninth Annual Technical Meeting of the Consortium for Fossil Fuel Liquefaction Science, Pipestem, WV, August 1995.

36. Robbins, G. A.; Winschel, R. A.; Burke, F. P. "Characterization of Coal/Waste Coprocessing Samples From HRI Run POC-2", presented at the 209th Annual Meeting of the American Chemical Society, Anaheim, CA, April 1995.

37. Anderson, R.; Derbyshire, F. J.; Givens, E.; Hager, T.; Kimber, G.; Lim, J.; Burke, F. P.; Lancet, M. S.; Robbins, G. A.; Winschel, R. A.; Stephens, H. P.; Kottenstette, R.; Peluso, M. "Advanced Process Concepts for Coal Liquefaction: Process Simulation Testing", presented at the 1994 DOE/NEDO Conference, Albuquerque, NM, September 1994.

38. Anderson, R.; Derbyshire, F. J.; Givens, E.; Hager, T.; Kimber, G.; Lim, J.; Burke, F. P.; Lancet, M. S.; Robbins, G. A.; Winschel, R. A.; Stephens, H. P.; Kottenstette, R.; Peluso, M. "Advanced Process Concepts for Coal Liquefaction: Process Simulation Testing", presented at the 1994 DOE Coal Liquefaction and Gas Conversion Contractors' Conference, Pittsburgh, PA, September 1994.

39. Winschel, R. A.; Zhou, P.-Z.; Klunder, E. B. "Premium Distillate Products from Direct Liquefaction of Coal", presented at the 1994 DOE Coal Liquefaction and Gas Conversion Contractors' Conference, Pittsburgh, PA, September 1994.

40. Zhou, P.-Z.; Winschel, R. A.; Klunder, E. B. "Premium Distillate Products from Direct Liquefaction of Coal", presented at the 208th National Meeting of the American Chemical Society, Washington, D. C., August 1994.

41. Brandes, S. D.; Robbins, G. A.; Winschel, R. A.; Burke, F. P. "Coal Liquefaction Process Streams Characterization and Evaluation: an Analytical Case Study", presented at the 1993 DOE Coal Liquefaction and Gas Conversion Contractors' Conference, Pittsburgh, PA, September 1993.

42. Derbyshire, F. J.; Givens, E.; Burke, F. P.; Winschel, R. A.; Lancet, M. S.; Stephens, H. P.; Kottenstette, R. J.; Peluso, M. "Improved Coal Liquefaction Through Enhanced Distillate Quality", presented at the 1993 DOE Coal Liquefaction and Gas Conversion Contractors' Conference, Pittsburgh, PA, September 1993.

43. Winschel, R. A. "Economic Benefits of Process Stream Characterization", for presentation at the DOE Workshop "Direct Liquefaction: Focused Research for Improved Economics", Pittsburgh, PA, September 1993. 
44. Winschel, R. A.; Lancet, M. S.; Robbins, G. A.; Burke, F. P.; Kottenstette, R. J.; Stephens, H. P. "Pretreatment of Coal and Recycle Oil for Direct Liquefaction", 7th International Conference on Coal Science, Banff, Alberta, Canada, September 1993.

45. Brandes, S. D.; Winschel, R. A.; Robbins, G. A.; Burke, F. P. "The Chemical Nature of Coal Liquid Resids and the Implications for Process Development", 1992 DOE Liquefaction Contractors' Review Conference, Pittsburgh, PA, September 1992.

46. Zhou, P.-Z.; Marano, J. J.; Winschel, R. A. "Strategic Considerations of Coal Liquid Refining", 204th National Meeting of the American Chemical Society, Washington, DC, August 1992.

47. Robbins, G. A.; Winschel, R. A.; Burke, F. P. "Conversion of Resid Components in CC-ITSL Processing at Wilsonville", 204th National Meeting of the American Chemical Society, Washington, DC, August 1992.

48. Brandes, S. D.; Winschel, R. A.; Burke, F. P. "The Chemical Nature of Coal Liquid Resids and the Implications for Process Development", 204th National Meeting of the American Chemical Society, Washington, DC, August 1992.

49. Winschel, R. A.; Burke, F. P.; Zhou, P. "Inspection of Integrated Two-Stage Liquefaction Products as Petroleum Refining Feedstocks", 1991 International Conference on Coal Science, University of New Castle Upon Tyne, UK, September 1991.

50. Burke, F. P.; Winschel, R. A.; Robbins, G. A. "Coal Cleaning for Liquefaction by Selective Agglomeration with Recycle Oils", 1991 International Conference on Coal Science, University of New Castle Upon Tyne, UK, September 1991.

51. Brandes, S. D.; Winschel, R. A.; Burke, F. P.; Robbins, G. A. "The Application of Advanced Analytical Techniques to Direct Liquefaction", 1991 DOE Liquefaction Contractors' Review Meeting, Pittsburgh, PA, September 1991.

52. Lancet, M. S.; Winschel, R. A.; Burke, F. P. "Stable Carbon Isotope Analysis of Coprocessing Materials", 1991 Summer National Meeting of the American Institute of Chemical Engineers, Pittsburgh, PA, August 1991.

53. Lancet, M. S.; Winschel, R. A.; Burke, F. P. "Stable Carbon Isotope Analysis of Coprocessing Materials", Fourth Chemical Congress of North America and 202nd National Meeting of the American Chemical Society, NY, NY, August 1991.

54. Brandes, S. D.; Winschel, R. A.; Burke, F. P. "The Application of Advanced Analytical Techniques to Direct Liquefaction", Fourth Chemical Congress of North America and 202nd Fall National Meeting of the American Chemical Society, NY, NY, August 1991. 
55. Winschel, R. A.; Zhou, P. "Inspection of Integrated Two-Stage Liquefaction Products by Petroleum Assay", Sixteenth Annual Electric Power Research Institute Fuel Science Conference, Palo Alto, CA, June 1991.

56. Robbins, G. A.; Winschel, R. A.; Amos, C. L. "Agglomeration of Low-Rank Coal as a Pretreatment for Direct Coal Liquefaction", 201st National Meeting of the American Chemical Society, Atlanta, GA, 4/14-19/91. (Am. Chem. Soc. Div. Fuel Chem. Prepr. 1991, 36(1), 58-66.)

57. Lancet, M. S.; Winschel, R. A.; Burke, F. P. "Application of Stable Carbon Isotope Analysis to Coal/Oil Coprocessing", 1990 DOE Direct Liquefaction Contractors' Review Meeting, Pittsburgh, PA, September 1990.

58. Winschel, R. A.; Burke, F. P.; Lancet, M. S. "Application of Stable Carbon Isotope Analysis to Continuous Coal/Oil Coprocessing", Symposium on Coprocessing of Coal with Petroleum Feedstocks, 200th National Meeting of the American Chemical Society, Washington, DC, August 1990. (Am. Chem. Soc. Div. Fuel Chem. Prepr. 1990, 35(4), 1032-1039.)

59. Burke, F. P. "Applications of Coal Liquefaction Solvent Quality Measurements", Frontiers in Coal Science \& Technology, Fukuoka, Japan, October 1989.

60. Burke, F. P.; Winschel, R. A.; Robbins, G. A. "Process and Recycle Oils in TwoStage Coal Liquefaction", 1989 International Conference on Coal Science, Tokyo, Japan, October 1989.

61. Winschel, R. A.; Burke, F. P.; Lancet, M. S. "Distinguishing Coal and Petroleum Reactions in Coal-Oil Coprocessing", 1989 International Conference on Coal Science, Tokyo, Japan, October 1989.

62. Winschel, R. A.; Burke, F. P.; Lancet, M. S. "Stable Carbon Isotope Analysis of Coprocessing Materials", 1989 DOE Direct Liquefaction Contractors' Review Meeting, Pittsburgh, PA, October 1989.

63. Burke, F. P.; Winschel, R. A. "Recycle Oils from Fluid Coking of Coal Liquefaction Bottoms", 1988 DOE Direct Liquefaction Contractors' Review Meeting, Pittsburgh, PA, October 1988.

64. Burke, F. P.; Winschel, R. A. "Donor Hydrogen Depletion in Coal Liquefaction", Fifth Annual International Pittsburgh Coal Conference, Pittsburgh, PA, September 1988.

65. Winschel, R. A.; Burke, F. P. "Recycle Oils from Fluid Coking of Coal Liquefaction Bottoms", 196th National Meeting of the American Chemical Society, Los Angeles, CA, September 1988 (In Processing and Utilization of High-Sulfur Coals III; 
Markuszewski, R. and Wheelock, T. D., Eds.; Coal Science and Technology 16; Elsevier: Amsterdam, 1990; pp 745-755.)

66. Burke, F. P.; Winschel, R. A. "Carbon Isotope Ratios of Fossil Fuels and Derived Products", presented at the Gordon Research Conference on Fuel Science, New Hampton, New Hampshire, July 1988.

67. Winschel, R. A.; Burke, F. P. "Stable Carbon Isotope Analysis of Coal/ Petroleum Coprocessing Products", Joint ACS Spring National Meeting and Third Chemical Congress of North America, Toronto, Ontario, Canada, June 1988.

68. Robbins, G. A.; Winschel, R. A.; Burke, F. P. "Determination of Phenolic -OH by FTIR for Coal Liquids Characterization", presented at the 22nd Middle Atlantic Regional Meeting of the ACS, Millersville, PA, May 1988.

69. Winschel, R. A. "Some Thoughts on Coal Structure: Implications from Coal Liquids Characterization", presented at the EPRI Workshop on Coal Structure, Monterey, CA, November 1987 (EPRI Report ER-6099-SR, November 1988).

70. Winschel, R. A.; Burke, F. P. "Coal and Petroleum Reactions in Coal/Oil Coprocessing", 1987 International Conference on Coal Science, Maastricht, Netherlands, October 1987.

71. Derbyshire, F. J.; Stansberry, P. G.; Burke, F. P.; Winschel, R. A. "Similarities in the Structural Units of Different Coals", International Conference on Coal Science, Maastricht, Netherlands, October 1987.

72. Winschel, R. A.; Burke, F. P. "Coal and Petroleum Reactions in Coal/Oil Coprocessing", DOE Direct Liquefaction Contractors' Review Meeting, Pittsburgh, PA, October 1987.

73. Winschel, R. A.; Robbins, G. A.; Burke, F. P. "Improvement in Coal Liquefaction Solvent Quality by Dewaxing", 1986 DOE Direct Liquefaction Contractors' Review Meeting, Monroeville, PA, October 1986.

74. Winschel, R. A.; Robbins, G. A.; Burke, F. P. "Improvement in Coal Liquefaction Solvent Quality by Dewaxing", 1986 Fall National Meeting of the ACS, Anaheim, CA, September 1986.

75. Winschel, R. A.; Robbins, G. A.; Burke, F. P. "Composition of Recycle Oil from HRI's Catalytic Two-Stage Liquefaction Process", 1985 DOE Direct Liquefaction Contractors' Review Meeting, Pittsburgh, PA, November 1985.

76. Wu, M. M.; Winschel, R. A. "Coal Desulfurization and Coal Conversion with Formates", Second Annual Pittsburgh Coal Conference, Pittsburgh, PA, September 1985. 
77. Robbins, G. A.; Winschel, R. A.; Burke, F. P. "Phenolic $-\mathrm{OH}$ as a Process Performance Indicator in Two-Stage Liquefaction", 190th National ACS Meeting, Chicago, IL, September 1985. (Am. Chem. Soc. Div. Fuel Chem. Prepr. 1985, 30(4), 155.)

78. Winschel, R. A.; Burke, F. P. "Process Oil Characteristics in Integrated Two-Stage Liquefaction (ITSL): Comparison of PDU and Pilot Plant Operations with Bituminous Coal", 190th National ACS Meeting, Chicago, IL, September 1985. (Am. Chem. Soc. Div. Fuel Chem. Prepr. 1985, 30(4), 172.)

79. Winschel, R. A.; Robbins, G. A.; Burke, F. P. "Correlation of Empirical and Analytical Measurements of Solvent Quality", 1985 EPRI Contractors' Conference on Coal Liquefaction, Palo Alto, CA, April 1985. (EPRI AP-4253-SR.)

80. Robbins, G. A.; Winschel, R. A.; Burke, F. P. "Determination of Phenolics in Coal Liquids by Infrared Spectroscopy", 1984 DOE Direct Liquefaction Contractors' Review Meeting, Albuquerque, NM, October 1984.

81. Winschel, R. A.; Robbins, G. A.; Burke, F. P. "Residual Oil Characteristics in TwoStage Liquefaction", Ninth Annual EPRI Contractors' Conference on Coal Liquefaction, Palo Alto, CA, May 1984. (EPRI Report AP-3825-SR, 3/85.)

82. Burke, F. P.; Winschel, R. A. "ITSL Process Oil Characterization: Wilsonville and Lummus", DOE Direct Liquefaction Contractors' Review Meeting, Pittsburgh, PA, November 1983.

83. Burke, F. P.; Winschel, R. A. "The Characterization and Performance of Recycle Solvents in Two-Stage Liquefaction", International Conference on Coal Science, Pittsburgh, PA, August 1983.

84. Winschel, R. A.; Burke, F. P. "Process and Product Oil Characterization in TwoStage Coal Liquefaction", EPRI Coal Liquefaction Contractors' Conference, Palo Alto, CA, May 1983. (EPRI AP-3366-SR.)

85. Moroni, E. C.; Burke, F. P.; Winschel, R. A.; Wilson, B. W. "Integrated Two-Stage Liquefaction - Solvent Quality Effects", ACS Spring National Meeting, Seattle, WA, March 1983. (Am. Chem. Soc. Div. Fuel Chem. Prepr. 1983, 28(1), 154.)

86. Burke, F. P.; Winschel, R. A. "Recycle Solvent Quality in Catalytic Coal Liquefaction", AIChE Spring National Meeting, Houston, TX, March 1983.

87. Burke, F. P.; Winschel, R. A. "Recycle and Process Oil Characterization in Integrated Two-Stage Liquefaction", DOE Contractors' Conference on Integrated Two-Stage Liquefaction, Albuquerque, NM, October 1982. 
88. Burke, F. P.; Winschel, R. A.; Jones, D. C.; Dudt, P. J.; DeGuiseppe, R. V.; Rosenhoover, W. A.; Raman, S. V. "Retrograde Reactions in SRC-1 Liquefaction", Seventh EPRI Coal Liquefaction Contractors' Conference, Palo Alto, CA, May 1982. (EPRI AP-2178)

89. Burke, F. P.; Winschel, R. A. "A Comparison of Recycle Slurry Oils from the SRC-1, $\mathrm{H}$-Coal and Lummus Two-Stage Liquefaction Processes", PETC Characterization of Coal-Derived Materials Meeting, Pittsburgh, PA, May 1982.

90. Burke, F. P.; Winschel, R. A. "Solvent Quality Effects in SRC-1, H-Coal and Lummus Two-Stage Liquefaction", Science and Technology of Synfuels: I. Colorado Springs, CO, March 1982.

91. Potts, J. D.; Chillingworth, R.S.; Hastings, K. E.; Schindler, H.; Burke F. P. "LC-Fining Support Activities for Two-Stage Liquefaction", AIChE Annual Meeting, New Orleans, LA, November 1981.

92. Burke, F. P.; Winschel, R. A. "Recycle Slurry Oils in the Lummus Two-Stage Liquefaction Process", DOE Integrated Two-Stage Liquefaction Contractors' Review Meeting, Saddle Brook, NJ, October 1981.

93. Burke, F. P.; Winschel, R. A. "H-Coal Slurry Oil Composition and Performance", ACS Fall National Meeting, New York, NY, August 1981. (Am. Chem. Soc. Div. Fuel Chem. Prepr. 1981, 26(3), 90.)

94. Burke, F. P.; Kleinpeter, J. A.; Jones, D. C.; Dudt, P. J. "Short Residence Time Coal Liquefaction with Selective Product Recycle", AIChE Winter National Meeting, Orlando, FL, 1981.

95. Burke, F. P.; Winschel, R. A. "Slurry Recycle Composition and Performance in HCoal PDU Operations", Sixth EPRI Coal Liquefaction Contractors' Conference, Palo Alto, CA, May 1981. (EPRI AP-2079-LD)

96. Burke, F. P.; Winschel, R. A.; Pochapsky, T. C. "Reverse Phase Liquid Chromotography of Coal Liquefaction Solvents", ACS Spring National Meeting, Atlanta, GA, March 1981. (Am. Chem. Soc. Div. Fuel Chem. Prepr. 1981, 26(2), 68.)

97. Burke, F. P.; Winschel, R. A.; Pochapsky, T. C. "Characterization and Performance of Recycle Solvents in the SRC-1 Process", PETC Characterization of Coal-Derived Materials Meeting, Pittsburgh, PA, May 1980.

98. Winschel, R. A.; Burke, F. P. "Liquid Column Fractionation (LCF)", PETC Characterization of Coal-Derived Materials Meeting, Pittsburgh, PA, May 1979. 
99. Kleinpeter, J. A. and Burke, F. P. "Conventional and Short Residence Time Coal Liquefaction Using Selective Product Recycle: I. Continuous Bench-Scale Studies, and II. Solvent Quality Effects", Fourth EPRI Coal Liquefaction Contractors' Conference, Palo Alto, CA, May 1979.

100. Kleinpeter, J. A., Jones, D. C., Dudt, P. J., and Burke, F. P. "Coal Liquefaction and Deashing Studies: I. CONSOL Synthetic Fuels Process", AIChE National Meeting, Philadelphia, PA, June 1978.

101. Kleinpeter, J. A., Jones, D. C., Dudt, P. J., and Burke, F. P. "Coal Liquefaction and Deashing Studies: II. Solvent Refined Coal Process", AIChE National Meeting, Philadelphia, PA, June 1978.

102. Kleinpeter, J. A. and Burke, F. P. "Short Residence Time Liquefaction Studies with Indiana V Coal and Wilsonville Based Solvents: I. Continuous Bench-Scale Tests, and II. Microautoclave Studies", Third EPRI Coal Liquefaction Contractors' Conference, Palo Alto, CA, May 1978.

\section{Invited Seminars}

103. Winschel, R. A. "Advances in Direct Coal Liquefaction" lecture in short course "Advanced Coal Technologies for the 21st Century", Pittsburgh, PA, September 1990 (in conjunction with the Seventh Annual International Pittsburgh Coal Conference).

104. Winschel, R. A. "Recycle Oils from Fluid Coking of Coal Liquefaction Vacuum Bottoms" at 1989 Fall Information Transfer Session of the Cooperative Program in Coal Research, The Pennsylvania State University, November 1989.

\section{Contracts Supporting CONSOL's Direct Coal Liquefaction Program}

105. DOE Contract DE-AC22-95PC95050, "Exploratory Research on Novel Coal Liquefaction Concept", 1995-1998.

106. DOE Contract DE-AC22-94PC93054, "A Characterization And Evaluation Of Coal Liquefaction Process Streams", 1994-2001.

107. Burns and Roe Services Corp. Subcontract No. 8273-1678 under DOE Contract DE-AC22-89PC88400, "Assessment of Analytical Methods and Sampling in Direct Coal Conversion Facilities", 1992-1993.

108. University of Kentucky/Center for Applied Energy Research Subcontract Under DOE Contract DE-AC22-91PC91040, "Advanced Direct Liquefaction Concepts for PETC Generic Units", 1992-2001. 
109. DOE Contract DE-AC22-89PC89883, "Coal Liquefaction Process Streams Characterization and Evaluation", 1989-1994.

110. DOE Contract DE-AC22-88PC88800, "Stable Carbon Isotope Analysis of Coprocessing Materials", 1988-1990.

111. DOE Contract DE-AC22-84PC70018, "Coal Liquefaction Process Solvent Quality Characterization and Evaluation", 1985-1989.

112. Gulf Research \& Development Co., subcontract to produce a large quantity of clean coal/oil agglomerates, 1982.

113. International Coal Refining Company Subcontract 01-13018-00, "Retrograde Reactions in SRC-I Liquefaction", 1980-1982.

114. DOE Contract DE-AC22-80PC30027, "Recycle Slurry Oil Characterization", 19801984.

115. Cities Service Research and Development Co., two separate subcontracts to characterize two-stage liquefaction oils, 1980.

116. DOE Contract DC-AC05-79ET14503, "Development of a Correlation Between Slurry Oil Composition and Process Performance", 1979-1980.

117. Electric Power Research Institute Research Project 1134-1, "Process Development for Improved SRC Options: Short Residence Time Studies", 1978-1980.

118. Fluor Contract 448434-9-K002 as part of U.S. DOE Contract EX-76-C-01-1517, 1975-1977. 